August $2003 \quad$ - NREL/SR-510-34272

\title{
Reaching the Environmental Community: Designing an Information Program for the NREL Biofuels Program
}

\section{May 2002 - May 2003}

J. Ames and C. Werner

Environmental and Energy Study Institute Washington, D.C.

\section{NPEI}

National Renewable Energy Laboratory

1617 Cole Boulevard

Golden, Colorado 80401-3393

NREL is a U.S. Department of Energy Laboratory

Operated by Midwest Research Institute $\bullet$ Battelle $\bullet$ Bechtel

Contract No. DE-AC36-99-G010337 


\title{
Reaching the Environmental Community: Designing an Information Program for the NREL Biofuels Program
}

\section{May 2002 - May 2003}

\author{
J. Ames and C. Werner
}

Environmental and Energy Study Institute Washington, D.C.

NREL Technical Monitor: H. Brown

Prepared under Subcontract No. ACO-2-32004-01

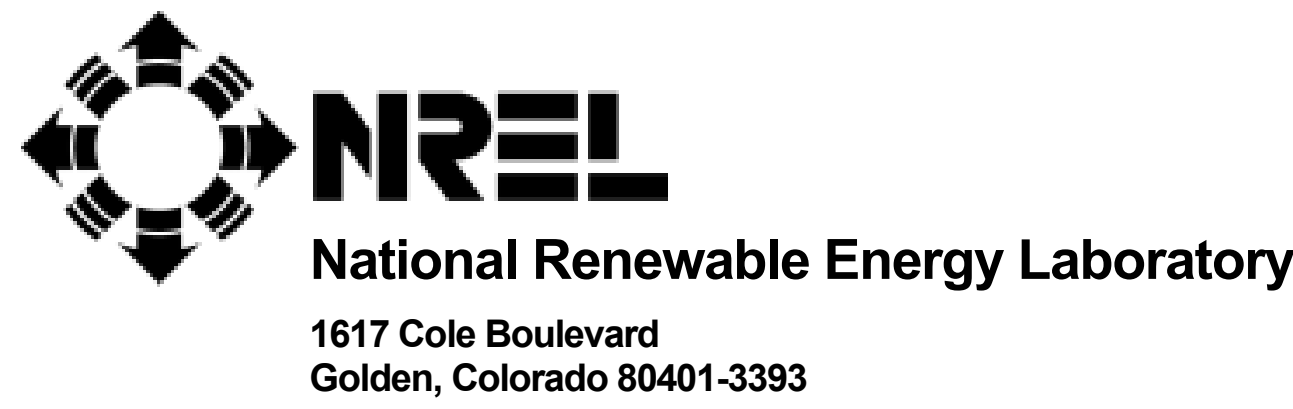

NREL is a U.S. Department of Energy Laboratory

Operated by Midwest Research Institute $\bullet$ Battelle $\bullet$ Bechtel

Contract No. DE-AC36-99-G010337 


\section{NOTICE}

This report was prepared as an account of work sponsored by an agency of the United States government. Neither the United States government nor any agency thereof, nor any of their employees, makes any warranty, express or implied, or assumes any legal liability or responsibility for the accuracy, completeness, or usefulness of any information, apparatus, product, or process disclosed, or represents that its use would not infringe privately owned rights. Reference herein to any specific commercial product, process, or service by trade name, trademark, manufacturer, or otherwise does not necessarily constitute or imply its endorsement, recommendation, or favoring by the United States government or any agency thereof. The views and opinions of authors expressed herein do not necessarily state or reflect those of the United States government or any agency thereof.

Available electronically at http://www.osti.gov/bridge

Available for a processing fee to U.S. Department of Energy and its contractors, in paper, from:

U.S. Department of Energy

Office of Scientific and Technical Information

P.O. Box 62

Oak Ridge, TN 37831-0062

phone: 865.576 .8401

fax: 865.576.5728

email: reports@adonis.osti.gov

Available for sale to the public, in paper, from:

U.S. Department of Commerce

National Technical Information Service

5285 Port Royal Road

Springfield, VA 22161

phone: 800.553.6847

fax: 703.605.6900

email: orders@ntis.fedworld.gov

online ordering: http://www.ntis.gov/ordering.htm 
Final Technical Report for Subcontract No. ACO-2-32004-01

"Reaching the Environmental Community: Designing an Information Program for the NREL Biofuels Program"

May 2002 - May 2003

Pursuant to subcontract ACO-2-32004-01 for the National Renewable Energy Laboratory (NREL), the Environmental and Energy Study Institute (EESI) completed a series of project tasks designed to engage the environmental community on the topic of biofuels. In doing so EESI has also been able to reach a wider audience including federal policymakers, agricultural stakeholders, and industry. Our primary communication tools have been our newsletter Ethanol, Climate Protection, Oil Reduction (ECO), and our highly regarded Congressional briefings. Under this contract, we held two Congressional briefings, one on the energy and environmental issues associated with biofuels production and use, and the other on implications of pending renewable fuels standard legislation, and published four ECO newsletters. Using these tools, EESI has been able to educate key stakeholders about the environmental benefits of biofuels, and spur new debate and discussion. Judging by the quantity and diversity of stakeholders we have been able to reach - ECO's readership is now over 600 and each of our briefings was standing room only - we have been very successful in bridging the knowledge gap among the stakeholders we targeted. EESI has brought timely policy analysis, air quality and energy research, and regional success stories to the forefront of the biofuel policy debate.

In addition, EESI provided the NREL Biofuels Program with a list of key environmental and energy stakeholders that will allow NREL to continue to conduct outreach to important biofuel stakeholders. Although we made significant progress, much work still needs to be done to reach consensus among these important parties. Although we believe we have effectively addressed many persistent misconceptions about the environmental aspects of biofuels, such as the energy balance question, without a continued proactive approach to addressing the environmental community's concerns these misconceptions may resurface. In fact we have received several requests to do additional briefings, and the readership to ECO continues to grow as our subscribers share the publication with their colleagues.

Appendix I contains the four editions of the ECO newsletter, produced under the contract. . Appendix II contains the speaker materials for the energy balance workshop and Appendix III contains the speaker materials for the renewable fuel standard workshop. All editions of ECO and briefing presentations can be also be found online at www.eesi.org.

\section{Task 1. Briefings}

EESI submitted a briefing plan in June 2002, which was reviewed by NREL staff. On July 31, 2002, EESI held its first briefing entitled "Environmental Qualities of Biofuels." The briefing sought to address two important questions: 1) Does Ethanol Require More Energy to Produce than it provides? and, 2) Should Biofuels be Part of a National Strategy to Mitigate Climate Change? These are two questions of major importance to both the environmental community and policymakers. EESI invited leading scientists on the subject to present their research, and answer questions from the audience. The briefing featured a panel of three leading 
experts in the field:

- Michael Wang, Ph.D., Transportation Environmental Scientist, Argonne National Laboratory, summarized his work calculating the net greenhouse gas emissions of both corn and cellulosic ethanol on a life-cycle basis. He argued that displacing gasoline with cellulosic ethanol would significantly reduce greenhouse gas emissions from the transportation sector. Dr. Wang's study is entitled "Effect of Fuel Ethanol Use on FuelCycle Energy and Greenhouse Gas Emissions," Argonne National Laboratory.

- Bruce Dale, Ph.D., Professor, Department of Chemical Engineering, Michigan State University, discussed his recently published study on the net energy balance of corn ethanol. Professor Dale's results are consistent with Wang's research as well as USDA's in finding that corn ethanol has a positive energy balance. Therefore, it can be concluded that using ethanol does displace the use of fossil fuels. Dr. Dale's study is entitled "Allocation Procedure in Ethanol Production System from Corn Grain," International Journal of Life Cycle Assessment.

- John Sheehan, Senior Engineer, National Renewable Energy Laboratory, detailed the air quality and greenhouse gas reduction benefits of biodiesel, another renewable biofuel. This study is entitled "Life Cycle Inventory of Biodiesel and Petroleum Diesel for Use in an Urban Bus," National Renewable Energy Laboratory. Sheehan also detailed his research on the potential of using corn stover, and abundant resource, as a feedstock for cellulosic ethanol production.

Over 100 individuals attended the event (standing room only) including 22 Congressional staff members, 18 federal agency officials, 9 public interest group representatives, 19 industry representatives, and four media representatives. After the panelists presentations, audience members took the opportunity to ask the panelists questions. Several questions focused on the specifics on the research, whereas others raised concern about the increased NOx emissions associated with both biodiesel and ethanol production. The panelists were able to address these questions, and remained afterward to talk to individual audience members one-on-one.

EESI held its second Congressional briefing on March 27, 2003, entitled "Enacting a Renewable Fuels Standard: Economic, Energy, and Environmental Implications." We received permission from NREL staff to hold the briefing at a later date than required by the subcontract so that it would coincide with the debate in both the House and Senate on enacting a Renewable Fuels Standard (RFS). The panel was composed of industry, state and local government officials, and a US Congressman, with the intent of illustrating the diversity of interests involved in the RFS debate. The briefing featured an expert panel of speakers including:

- Michael Whatley, Staff Director, Senate Subcommittee on Clean Air, Climate Change and Nuclear Safety, Senate Environment and Public Works Committee, provided an overview of the proposed RFS legislation. Both the House and Senate proposals would require the use of 5 billion gallons of renewable fuel, by 2015 and 2012 respectively. Both bills also repeal the federal oxygenate requirement for reformulated 
fuels. The Senate bill also bans the fuel additive MTBE, which has been found to contaminate drinking water when leaked from underground storage tanks.

- Ken Colburn, Executive Director, Northeast States for Coordinated Air Use Management (NESCAUM), gave an overview and history of the oxygenate requirement for reformulate fuels. Colburn spoke about the environmental issues at stake with the proposed RFS, including MTBE contamination, air quality, and greenhouse gas emissions. The compromise RFS agreement, he argued, would provide greater flexibility for the Northeast in achieving its air quality goals.

- Dan Dorman, Member, Minnesota House of Representatives, spoke about Minnesota's experience with requiring all gasoline sold in the state to be blended with ethanol, and the rural economic development the program has fostered. Minnesota requires nearly all gasoline sold in the state to be blended with 10 percent ethanol, and provides a 20-cent per gallon producer payment. As a result, the state now has 13 ethanol plants, the majority of which are farmer owned, which employ more than 400 people.

- Alice Durkee, Vice President, Masada Resource Group, talked about the potential for expanding ethanol production across the country by utilizing cellulosic feedstocks, as well as Masada's plans to open the first commercial cellulosic plant in the U.S. in Middletown, New York. Masada's facility will make use of the organic portion of municipal solid waste as a feedstock to produce cellulosic ethanol. The facility is expected to create 200 jobs.

- Dr. Edward Murphy, Downstream General Manager, American Petroleum Institute, provided the perspective of the petroleum industry in implementing a national RFS. Murphy said that petroleum refiners are greatly concerned about the cost of complying with uncoordinated state MTBE bans, and argued for a nationwide ban of the fuel additive. In addition, with the banking and trading provisions in the RFS proposals, no significant increase in gasoline costs is expected to result from implementing the RFS.

- Congressman Gil Gutknecht (R-MN) spoke about Minnesota's success with ethanol, and the importance of biofuels in achieving national energy security.

Over 100 individuals attended the event including 30 Congressional staff members, 6 federal agency officials, 15 public interest group representatives, 22 industry representatives, and six media representatives. During the question and answer period, several audience members posed questions to the speakers about the nature of the RFS agreement, and why the panelists were in favor of an RFS. As always, the panelists remained afterward to talk to individual audience members one-on-one

Briefing notices for both briefings were distributed not only to all decision-maker offices but also to a large database of over 4000 individuals/organizations, including many grassroots organizations and other contacts across the country as a result of our expanded use of electronic communications. In addition, a variety of publications (e.g., CQ Monitor, BNA, AP Day Book) posted our briefing notices.

We have received overwhelmingly positive feedback on both briefings from Congressional staff and other attendees. In addition, we have received many requests for more information on biofuels. After each briefing we posted the panelists' presentations, handouts, and studies on EESI's website: http://www.eesi.org/briefings/brief.htm (under July 2002 and March 2003). 


\section{Task 2. Stakeholder List}

EESI provided NREL staff with a list of 56 key environmental and energy stakeholders. We organized the list into categories including: public health, industry, state and local government, and academia. This list represents several years of work by EESI to cultivate relationships within the environmental and energy communities. We are confident that these contacts will provide NREL staff with valuable and unique perspectives.

\section{Task 3. Newsletter}

EESI's Ethanol, Climate Protection, Oil Reduction (ECO) newsletter now reaches more than 600 subscribers representing a diverse cross-section of ethanol stakeholders from the environmental and public health communities, industry, academia, all levels of government, and throughout the world, including subscribers from Australia, Brazil, Canada, China, Columbia, Egypt, Italy, the Netherlands, Spain, Uganda, and the United States. In ECO we have tracked pending federal and state biofuel legislation, reported on the latest research, provided updates on innovations in the ethanol industry (in our "News Briefs" section), and printed unique commentary submissions, most recently from a U.S. Congressman. We continue to receive overwhelmingly positive feedback on the publication.

All editions of ECO are available on EESI's website at:

http://www.eesi.org/publications/pubs.htm.

APPENDIX I: ECO Newsletter editions 17-20

APPENDIX II: Speaker materials for briefing I — "Environmental Qualities of Biofuels" APPENDIX III: Speaker materials for briefing II — "Enacting a Renewable Fuels Standard: Economic, Energy, and Environmental Implications" 


\section{Appendix I \\ ECO Newsletter editions 17-20}




\title{
$\mathrm{E}_{\text {THANOL }}$
}

\section{Climate Protection \\ Oil Reduction}

\author{
A PUBLIC FORUM
}

VOL. 3, ISSUE III

MAY 2003

WELCOME TO “ECO.” THIS NEWSLETTER IS WRITTEN TO PROVIDE THE MOST CURRENT INFORMATION ABOUT ETHANOL AND SERVE AS A PUBLIC FORUM. THE ENVIRONMENTAL AND ENERGY STUDY INSTITUTE (EESI) HOPES TO BUILD CONSENSUS WITHIN THE ENVIRONMENTAL COMMUNITY REGARDING THE POTENTIAL BENEFITS OF ETHANOL - AND PARTICULARLY THE EXPANDED OPPORTUNITIES PROVIDED BY CELLULOSIC ETHANOL - WITH A SPECIAL FOCUS ON CLIMATE PROTECTION. ETHANOL CAN ALSO BE A POLITICAL BRIDGE TO BROADER ALLIANCES IN SUPPORT OF CLIMATE INITIATIVES.

MANY IN THE ENVIRONMENTAL COMMUNITY HAVE MADE STRONG STATEMENTS IN SUPPORT OF ETHANOL AS A LOWCARBON FUEL WITH LARGE POTENTIAL BENEFITS TO REDUCE LIFE-CYCLE GREENHOUSE GAS (GHG) EMISSIONS. ETHANOL ALSO REDUCES CARBON MONOXIDE EMISSIONS AND OUR RELIANCE ON OIL, CONTAINS NO SULFUR AND HELPS TO ELIMINATE SMOG THROUGH ITS USE AS AN OXYGENATE FOR GASOLINE. CELLULOSIC ETHANOL, PRODUCED FROM AGRICULTURAL WASTES, WOOD WASTES OR ENERGY CROPS, PROVIDES EVEN GREATER GHG EMISSION REDUCTIONS THAN CORNBASED ETHANOL, PROMOTES RURAL ECONOMIC REVITALIZATION AND OFFERS A SOLUTION TO WASTE DISPOSAL PROBLEMS. HOWEVER, THERE HAVE BEEN CONCERNS ABOUT ETHANOL RANGING FROM VOLATILE ORGANIC COMPOUNDS (VOCS) TO CORPORATE WELFARE. ECO ADDRESSES THESE AND OTHER ISSUES. PLEASESHARE YOUR VIEWS WITH US AND WE WILL ADDRESS THEM IN “ECO." 


\section{COMMENTARY}

\section{RENEWABLE FUELS -- LET'S DO IT By U.S. House Representative Collin C. Peterson (D-MN)}

Because America's energy needs are likely to continue growing into the foreseeable future, it is imperative that we in Congress do all we can to promote and grow opportunities for production of environmentally friendly renewable fuels. At present, renewable fuels provide for only a small part of our needs, but the possibilities in this area are vast and we should be doing all we can to encourage and develop all of these options.

Renewable fuels are not only important for addressing the nation's overall energy needs, they are also an essential component of our efforts to strengthen agricultural sectors of the country and revitalize rural economies. Value-added agricultural products like ethanol and other biofuels are environmentally friendly energy products that can be used to create and expand agricultural product markets.

This Congress I introduced legislation, H.R. 837, which has largely the same language that was included in the Senate-passed energy bill from the $107^{\text {th }}$ Congress (S. 385). My bill would have created a renewable fuels program requiring gasoline sold or dispensed in the United States to contain 2.3 billion gallons per year of renewable fuels in 2004, and 5 billion gallons per year by 2012. It also would have eliminated the Reformulated Gasoline Oxygen requirement and create a credit-trading program to give refiners more flexibility in using renewable fuels. In addition, it also would have completely phased out the use of MTBE, an oxygenate used in gasoline known to contaminate groundwater.

When the House began to develop its Energy bill for this session, I took my bill to Chairman Tauzin and he listened to what I had to say about the renewable fuels title, in part because I had helped to get strong language and funding for renewable fuels into the recently enacted Farm Bill, including support for ethanol, biodiesel, and wind energy. Other Members - particularly Congressman Shimkus and Speaker Hastert - made critical contributions as well to this bipartisan effort on behalf of renewable fuels and in the end we got much of what we were working for in the House bill, including the Renewable Fuels Standard, which includes biodiesel.

Minnesota leads the country in promoting the use of ethanol. We are the first and only state to meet the goals of the federal Energy Policy Act of 1992, legislation enacted to reduce the nation's dependence on foreign oil, by blending nearly all of our gasoline with 10 percent ethanol. A current state program requires statewide use of oxy-fuel, an ethanol blend, providing a 20-cent per gallon incentive for ethanol producers. For every dollar invested by the State, $\$ 11$ of economic benefit is generated. Minnesota's ethanol industry boots the economy by more than $\$ 400$ million, and provides over $\$ 15$ million in taxes. Minnesota has 13 ethanol plants, 5 of which are in my Congressional District in Western Minnesota. These plants employ more than 400 people and have about 7,000 farmer-investors.

Our national energy policy should be long-term, domestically focused, designed to reduce dependence on foreign oil, and promote practical and cost-efficient conservation. The ethanol industry is expanding to meet the demands under current law. Sixteen states have phased out MTBE and ethanol takes its place as an oxygenate. U.S. ethanol fuel production was 2.13 billion gallons in 2002, but U.S. ethanol fuel production capacity is 3.2 billion gallons/year, and growing. A robust renewable fuels standard like the one proposed in H.R. 837 will help ethanol producers meet the growing demand for ethanol nationwide.

On April 11, the House passed H.R. 6, the Energy Security Act of 2003, which requires gasoline sold or distributed in the United States to contain 5 billion gallons per year of renewable fuels by 2015 . I 
supported it in large part because of the provisions within the renewable fuels title of the bill. We didn't get everything we wanted, but it was a good compromise - balanced and sensible - and I think it will serve to support and expand opportunities in the renewable fuels industry.

But now comes the hard part. One of the biggest problems we have in Congress stems from those individuals who are philosophically rooted in intransigent positions; they demand conformity, reject compromise and ignore changing circumstances. This kind of "all or nothing" thinking is present on both sides of the political aisle and that's why often times it seems like nothing gets done in Congress.

Compromise and a willingness to listen, learn and reconsider issues and policies in the light of changing circumstances is at the heart of our representative system of government. To develop solutions to the real problems we face, Congress is going to have to do more of this kind of thing instead of drawing lines in the sand. In my view, the House passed Energy bill represents a compromise that includes a good plan for renewable fuels, but we're going to need 51 Senators who feel the same way about that in order to get it done.

The challenge of getting an Energy bill that is good for ethanol and other biofuels passed and signed into law provides Congress with yet another opportunity to break this cycle, but like most things, it will take some work. It will take people willing to work with all sides in order to find sensible and balanced solutions to difficult questions. This approach often puts people like me in the middle, between the ideologues on both sides. However, in my view it is "in the middle" where workable and inclusive solutions are frequently found.

Members worked together in good faith on the Energy bill's renewable fuels provisions, and although we didn't get everything we wanted we accomplished a great deal -- particularly for ethanol and other renewable biofuels - and we'll keep working on it at every opportunity to make it even better. Now that the House bill has passed it's my hope that the Senate will be able to avoid the narrow and divisive issues that stalled the Energy bill in the last Congress. I'd like to think that when Senators - particularly those in "farm states" - take a look at the renewable fuels title of the House passed bill they will realize that this is a good deal for their constituents, something well worth their support. I'm hoping that Senators "keep their eye on the ball" and don't get polarized and locked in by pre-existing ideologies. I hope they will see that what we've done in the House is good for renewable fuels and come to a compromise as well.

Compromise has worked in the House. We need a broad coalition of constituent organizations to help us urge the Senate to do the same thing. Renewable fuels are good for the environment, good for farmers and energy consumers, good for rural economies, good for urban and suburban air quality and good for the future of our nation. We need to look at the big picture, support the renewable fuels industry and get this done.

\section{Dr. EdWARD Murphy, Downstream General MANAGER, AMERICAN PETROLEUM INSTITUTE}

The American Petroleum Institute (API) and its member companies welcome the commitment that the new Congress has shown to addressing the fuel supply problems facing U.S. fuel providers and consumers. Both houses have taken significant action in shaping fuels legislation - but much work remains before this urgently needed legislation wins final approval and is sent to the President.

Time is of the essence because individual state MTBE bans will start to take effect soon, with Connecticut's starting in October and New York's and California's bans beginning in January 2004. Differing start dates and gasoline requirements from various states, combined with a federal oxygenate 
requirement for reformulated gasoline (RFG), will complicate an already tight fuels system and increase the potential for disruptions in the supply and distribution system.

API believes Congress should repeal the oxygen content requirement for reformulated gasoline that is in the Clean Air Act and require a national phasedown of MTBE. As part of the package that meets these objectives, we also support a renewable fuels standard that phases up to 5 billion gallons over several years nationally, with an averaging and credit trading program to allow the use of renewable fuels where most feasible and cost-effective. In addition, we support provisions that would protect and enhance the environmental benefits already achieved from reformulated gasoline.

Repeal of the oxygen requirement and a significant reduction in the use of MTBE were two of the key recommendations of the U.S. Environmental Protection Agency's 1999-2000 Blue Ribbon Panel on Oxygenates in Gasoline. Three years have passed since those recommendations were made.

These steps are a much better solution than the alternative-which is continued state MTBE bans and further aggravation of the already troublesome situation of a patchwork of fuels requirements across the country. A solution that relies on state-by-state MTBE bans to fix the problem is not efficient and will exacerbate supply problems that are likely to arise out of uncoordinated and disjointed state requirements. Unique state fuel requirements isolate affected markets, and, in the event of a supply disruption, could cause shortages and price volatility, as experienced in two of the last four years in Chicago and Milwaukee. Sixteen states already have enacted MTBE bans or caps and additional states are considering bans.

In the absence of federal legislation, consumers will be subject to the uncertainties posed by uncoordinated state actions. While individual states are restricting the use of MTBE, they cannot change the federal RFG oxygen content requirement. That requirement is unnecessary, uneconomical and inflexible. It requires the use of an oxygenate in each gallon of gasoline in RFG areas. Maintaining the status quo - with the federal RFG oxygen requirement in place and states continuing to ban MTBE - will require using ethanol in RFG areas where it may not be cost-effective. Alternatively, other states may pursue solutions that further fragment the market in new and different ways.

It's important to recognize that the cost of an approach that includes a federal phasedown of MTBE, repeals the federal RFG oxygen content requirement and includes a renewable fuels standard with a flexible national averaging, banking and trading program would be less than maintaining the status quo of state MTBE bans and maintaining the federal RFG oxygen requirement. A study by the U.S. Department of Energy (DOE) revealed that the cost of the renewable fuels standard would be minimal, between 0.5 and 1.0 cents per gallon and likely less with an effective banking and trading system. Importantly, a stateof-the-art study in 2002 by MathPro, Inc., a leading economic analysis firm, concluded that replacing the 2 percent oxygen requirement with the renewable fuels standard would be less costly than the status quo outcome of continued state MTBE bans and continuation of the federal RFG oxygen requirement.

The provisions outlined here are supported by an historic coalition, including API, numerous farm and ethanol interests, Northeast state air quality officials, and environmental interests. They offer carefully considered solutions to the fuels problems that have challenged fuel providers and burdened energy consumers, and protect important environmental benefits achieved by reformulated gasoline.

\section{As always, EESI welcomes your comments about the issues raised in this commentary and throughout ECO. Responses, article and commentary submissions, and feedback can be sent to eco@eesi.org}




\section{RFS Advances in House and Senate}

On April 11th, the U.S. House of Representatives approved a comprehensive energy bill, H.R. 6. The bill includes a Renewable Fuels Standard (RFS) that requires the use of five billion gallons of renewable fuels a year by 2015. "This specific provision will mean more to rural America than even the Farm Bill," Rep. John Shimkus (R-IL) stated. "It will give farmers a new market for their crops, increase investment in rural America, decrease our reliance on foreign oil, and provide for a cleaner environment."

This enthusiasm is echoed by Ken Cole, Vice President of Government Relations for General Motors: "Establishing domestic renewable sources of energy can diversify our fuel supply and provide an opportunity to enhance energy security by reducing petroleum energy usage."

\section{$\underline{\text { H.R. } 6}$}

Similar to its Senate counterpart, S. 791, the House bill eliminates the oxygenate requirement of the 1990 Clean Air Act, but unlike the Senate bill it does not ban MTBE. An amendment offered by Rep. Lois Capps (D-CA) in the House Energy and Commerce Committee to include an MTBE ban failed by 18-32, meaning that the banning of the controversial fuel additive would continue on a state-by-state basis. Both S. 791 and H.R. 6 allow 1 gallon of cellulosic ethanol to be credited as 1.5 gallons of renewable fuel as an incentive to spur the development of cellulosic ethanol facilities. H.R. 6 would also extend the Senate's "safe harbor" provision, which exempts renewable fuels producers from certain product liability claims, to MTBE producers, This will be controversial in conference with the Senate.

\section{$\underline{\text { S. } 791}$}

S. 791, the Senate's version of RFS legislation, is nearly identical to S. 385 , the fuels compromise reached as part of last year's comprehensive energy bill that ultimately died in the Senate and House conference committee.
S. 791 was referred out of the Senate Environment and Public Works Committee (EPW) on April 9, 2003, and will likely be offered as an amendment to the Senate energy bill when it reaches the floor. S. 791 requires that five billion gallons of renewable fuel additives be sued in the nation's fuel supply by 2012, eliminates the oxygenate requirement, and calls for a national ban on MTBE.

At the Senate EPW markup, an amendment from Lisa Murkowski (R-AK) was passed that exempts Alaska and Hawaii from ethanol requirements. Several amendments sponsored by Sen. Hillary Clinton (D-NY) and Sen. Barbara Boxer (D-CA) were also approved, including: increased incentives for $\mathrm{R} \& \mathrm{D}$ for cellulosic ethanol; requirements for broadening the scope of public health studies on the effects of fuel additives to include pregnant women, children, and minorities; and loan guarantees for conversion of solid waste facilities to produce ethanol. An amendment from Sen. Boxer that would have removed the safe harbor clause in $\mathrm{S}$. 791 for ETBE producers was defeated 9-10.

S. 791 is scheduled to begin debate on the Senate floor on May 6. Debate over amendments to the energy bill is apt to last several weeks.

\section{EPA Requests More Information on New York Waiver Request}

In early April, the U.S. Environmental Protection Agency (EPA) informed New York that it is unable to act on the state's request for a waiver from the federal oxygenate requirement in the area surrounding Manhattan.

New York State officials had argued that replacing MTBE with ethanol would prove too costly for oil producers, who would have been forced to import the ethanol from out-of-state producers. State officials had also objected to implementing MTBE bans on a state-by-state basis, arguing that a national ban on MTBE was needed: "The only way to develop a consistent region wide approach to RFG or any fuel is for the federal government to establish the 
standards," said Dan Gilbert of the New York State Department of Environmental Conservation.

EPA could not act on New York's request for a waiver of the Clean Air Act's reformulated gasoline oxygenate standard because of a 'lack of technical information' supporting the request. In a letter to New York's Environmental Conservation Commissioner Erin Crotty, EPA Assistant Administrator Jeffrey Holmstead wrote: "[T]he application and supporting information fail to address the requirements specified in the [Clean Air Act] statute. Without the necessary technical supporting documentation, we are unable to evaluate the merits of the request and can take no further action."

EPA's response to NY comes as another Northeast state, Connecticut, is in the process of deciding whether to move the deadline for a state-wide MTBE ban. The Connecticut ban was originally mandated in a 2000 bill that called for the removal of the controversial gasoline additive by October 1, 2003. However, on March 17 the Environment Committee of the Connecticut General Assembly approved moving the state's MTBE ban to January 1, 2004, so that the ban would coincide with New York's deadline. The bill (S.B. No. 840) was then referred to the Transportation Committee of the General Assembly for review, which passed the bill on April $15^{\text {th }}$. If passed by the Senate, it will be voted on by the General Assembly sometime before the first week of June.

California made a similar waiver request, which was rejected by EPA in June, 2001. Governor Gray Davis (D) subsequently delayed the states MTBE phase-out by one year until December $31,2003$.

\section{LEGISLATIVE UPDATES}

\section{Senate Finance Committee Passes Ethanol Excise Tax MODIFICATION}

On April 3, the Senate Finance Committee finished marking up the Energy Tax Incentives Act of 2003 (S. 597). The bill is designed to more accurately target small ethanol producers, direct more tax revenue toward the Highway Trust Fund, and creates a new volumetric ethanol excise tax credit (VEETC) of 5.2 cents on a 10 percent ethanol blend.

Recent years have seen a sharp growth in the amount of farmer-owned cooperative ethanol plants. This trend has allowed individual producers to become more competitive in the market, but individual owners within the cooperative do not currently have access to the credit. If enacted, each farmer-owner would receive the ten-cent per gallon tax credit on his or her share of the company's production in any given year.

Also, as the small ethanol producer program is currently structured, a small ethanol producer can manufacture no more than 30 million gallons of ethanol per year in order to qualify for a 10 cent per gallon tax credit for the first 15 million gallons of production per year. The legislation would update the definition of a small ethanol producer from a maximum production of 30 million gallon per year to 60 million gallons. The credit was originally designed to help smaller-scale producers gain a foothold in the ethanol market. However, farmer-owned plants now routinely produce 40 to 50 million gallons each year, which rendered the 30 million gallon limit outdated.

The bill also ensures that the entire excise tax paid on ethanol-blended gasoline would be transferred to the Highway Trust Fund (HTF). Currently, 2.5 cents of the federal excise tax paid on ethanol-blended fuels goes to the government's general fund instead of being 
transferred to the HTF. This has been fertile ground for many critics of the excise tax, who argue that ethanol-blended fuels effectively removed revenue from the HTF. The proposed change would add approximately $\$ 600$ million in annual revenues to the HTF.

\section{RESTRUCTURING THE TAX CREDIT}

Most notably, S. 597 restructures the ethanol excise tax exemption so that ethanol-blended fuels make the same contribution per gallon to the HTF as regular gasoline. Currently, regular gasoline is taxed at the rate of 18.4 cents per gallon, and ethanol-blended fuel is taxed at a much lower rate $(5.2$ cents on a 10 percent blend). S. 597 eliminates the existing ethanol excise tax exemption and requires that both gasoline and ethanol-blended gasoline be taxed at the same 18.4 cent rate. The revenue from this tax will be transferred to the federal government's General Fund (GF), and then transferred to the HTF. The tax credit would be taken from the General Fund and not from the HTF. This requirement - that the excise tax credit come from the General Fund as opposed to the $\mathrm{HTF}$ - adds approximately $\$ 1.4$ billion to HTF revenue annually.

\section{RESEARCH \& DEVELOPMENT}

\section{USDA ANNOUNCES NOTICE OF FUNDING AVAILABILITY (NOFA) FOR SECTION 9006 OF 2002 FARM BILL}

The Rural Business-Cooperative Service (RBS) has published a solicitation for the Renewable Energy Systems and Energy Efficiency Improvements Program, which is authorized under Section 9006, Title IX of the 2002 Farm Bill. The bill makes available $\$ 23$ million in competitive grant funds for fiscal year (FY) 2003 to purchase renewable energy systems and make energy efficiency improvements for agricultural producers and rural small businesses. According to Assistant Secretary of Energy David Garman, "this investment will pay dividends to the whole of our country. Rural America can help to fulfill the promise of the President's National Energy Plan in expanding the nation's overall supply of clean and affordable energy for a new century of economic growth."

Due to the time constraints for implementing this program, RBS has decided to institute only the grant program (no loans) for FY 2003.

Applications must be completed and submitted to the appropriate US Department of Agriculture (USDA) State Rural Development Office by June 6, 2003. Applications for renewable energy systems must be between $\$ 10,000$ and $\$ 500,000$, and applications for energy efficiency improvements must be between $\$ 10,000$ and $\$ 250,000$. The grant request must not exceed 25 percent of the eligible project costs, and the applicant must be an agricultural producer or rural small business, have a demonstrated financial need, and be located in a rural area. Eligible uses of funds include the purchase and installation of equipment, construction of or improvements to existing facilities, retrofitting, energy audits, and several other expenses relating to the start-up of the project. Ineligible uses of funds include land acquisition, capital leases, working capital, vehicles, or funding of political or lobbying activities, to name a few.

It must be noted that future funding for Section 9006 is not secure. Although funded for FY03, the administration has proposed cutting $\$ 20$ million from the program in FY04. A similar funding cut has also been proposed for the Value-Added Agricultural Market Product Development Grants program, an initiative designed to help farmers develop and market innovative new uses for their crops. On April 7, a "Dear Colleague" letter was sent by a bipartisan group of 39 U.S. Representatives to the House Appropriations Committee in order to restore mandatory funding (as provided for in the 2002 Farm Bill) to the two programs for FY04. The House and Senate Appropriations committees have not scheduled markups for FY04. 
On April 23, a group of 20 trade associations and environmental organizations sent a letter detailing ways to improve the response to the NOFA, especially from family farmers and others of limited financial means. A similar letter was also sent by the National Association of State Offices (NASEO). For further details on the Section 9006 NOFA and the "Dear Colleague" letter, please visit www.eesi.org.

\section{RECENT STUDIES}

\section{SURVEY OF AMERICAN FARMERS HIGHLIGHTS SUPPORT FOR DEVELOPMENT OF RENEWABLE ENERGY ON FARMS}

A recent survey completed by Robinson and Muenster Associates, Inc. of South Dakota, and sponsored by the American Corn Growers Foundation (ACGF), found extensive support among farmers for the development of renewable energy. The survey included 511 farmers from 14 different states who cumulatively represent the planting of 86 percent of the nation's corn in 2003.

Farmers surveyed stated that the federal and state government should provide incentives like production tax credits in order to spur the development of wind-energy in rural America. According to Dan McGuire, ACGF Program Director and project director of the organization's "Wealth from the Wind" program, " $77.9 \%$ believe farmers should be offered financial incentives such as production tax credits..." When asked about The Renewable Energy System and Energy Efficiency Improvements program, Section 9006 of the Energy Title, $82.2 \%$ of corn producers surveyed expressed support.

The survey also showed the extent to which farmers are willing to play in the development of renewable energy. McGuire added that " $93.3 \%$ of the nation's corn producers support wind energy, $88.8 \%$ want farmers, industry and public institutions to promote wind power as an alternative energy source and $87.5 \%$ want utility companies to accept electricity from wind turbines in their power generation mix."

\section{BIOMASS R\&D TECHNICAL ADVISORY COMMITTEE AND INTERAGENCY BOARD BEGIN JOINT MeETINGS}

On February 24-25, 2003, the Biomass R\&D Technical Advisory Committee (Advisory Committee) and the Interagency Biomass R\&D Board held their first joint meeting. The two groups were originally established by the Biomass Research and Development Act of 2000 to "coordinate the biomass-related programs within and among federal departments and agencies." The Committee is also charged with educating policy makers and the public on the potential for biomass to increase energy independence and energy security, and the role that the federal government might play in spurring such a movement. The Interagency Board is co-chaired by the Departments of Energy and Agriculture, and is overseen by roughly 25 individuals from trade associations, environmental organizations, academia, private industry and government. Additional member government agencies include the Department of Interior, Environmental Protection Agency, National Science Foundation, Office of Science and Technology Policy, and Office of the Federal Environmental Executive.

At this first joint meeting, the Committee reached consensus that biomass can and will play an integral part in enhancing national energy security, but cautioned that biomass is not getting the financial backing necessary to its success. They noted that in addition to general budget decreases in the biomass arena for FY04, innovative areas of research like co-firing and black-liquor gasification "have either been cut or will be cut in the FY 2004 budget," according to Biomass R\&D's website. The Committee also 
cautioned against diverting attention away from biomass toward newer projects, such as hydrogen initiatives that have received significant attention of late

The meeting is the outgrowth of several documents produced by the Advisory Committee in 2002. In October 2002, the Advisory Committee authored a "Vision for Bioenergy and Biobased Products in the United States," which asserted that "by 2030, a wellestablished, economically viable, bioenergy and biobased products industry will create new economic opportunities for rural America, protect and enhance our environment, strengthen U.S. energy independence, provide economic security, and deliver improved products to consumers." December 2002 saw the release of the Committee's "Roadmap for Bioenergy and Biobased Products in the United States," which outlines the research and development that will be needed in order to satisfy that vision.

In preparation for the meeting, each government agency of the interagency board was required to provide a comprehensive summary of each office's respective biomass activities. Not surprisingly, the Department of Energy (DOE), the Department of Agriculture (USDA), and the National Science Foundation (NSF) were found to be the agencies most invested in biomassrelated research and development. In FY03, DOE's budget for its Biomass Program is roughly $\$ 114$ million, with most of its funding going towards project in the areas of making plastics and chemicals from renewable, biobased materials, and improving technology for biomass power, as well as biofuels like ethanol and biodiesel. USDA's FY03 budget is approximately $\$ 259$ million for biomass activities and is aimed at research on bioconversion, agronomic practices, implementation of the 2002 Farm Bill, and the distribution of incentives overseen by its Commodity Credit Corporation. The National Science Foundation has a biomass budget of roughly $\$ 50$ million for FY03, and is focused on primarily biomass research and education in the fields of metabolic engineering, biotechnology, plant biology, and genomics.
For more information about the Biomass R\&D Technical Advisory Committee, please visit http://www.bioproducts-bioenergy.gov.

\section{REPORT FINDS ETHANOL NOT RESPONSIBLE FOR PRICE SPIKES IN CALIFORNIA}

\author{
At the request of Governor Gray Davis, the \\ California Energy Commission (CEC) issued a \\ report on March 28, 2003, entitled "Causes for \\ Gasoline \& Diesel Price Increases in \\ California." The report explains the reasons \\ behind the dramatic leap in California's gas \\ prices from $\$ 1.58$ a gallon on January 1, 2003, \\ to $\$ 2.15$ a gallon on March 17, 2003 - an \\ increase of 57 cents.
}

Given California's ban of the fuel additive MTBE and the increasing amount of ethanol being blended in California's gasoline, speculation grew as to whether ethanol was to blame for the price spikes. Critics of ethanol such as Senator Dianne Feinstein (D-CA), previously had warned that substituting ethanol for MTBE could have "unanticipated side effects, such as supply problems [and] resulting in higher gasoline prices for the consumer." As gasoline prices rose dramatically in the first quarter of 2003, critics cited supply-side issues with ethanol as among the possible reasons for the rises in price.

However, the CEC's report dismisses the idea that the rise in prices is due to ethanol. Instead, the report points out that although California refineries produce 44 million gallons of gasoline a day, the state still imports roughly 100 million gallons of gasoline and blend stocks each month to meet demand. And, as long as this is the case, California's gasoline prices will be inextricably bound to the volatile petroleum market: "What primarily drove this year's increases to recordsetting levels was the unusually high cost of crude oil on the world market. The price of 
crude oil on the world market nearly doubled in the past year due to market uncertainty about the threat of war in the Middle East. Other factors included an oil strike in Venezuela that drastically cut supplies and a cold winter in the Eastern U.S. that increased the need for heating oil." The report also found a host of other potential causes, including delayed maintenance and unexpected production problems among California's refineries.

The report also explicitly states that ethanol most likely had no role in the dramatic increases in price. Because almost all major California refiners began to make the switch from MTBE to ethanol ahead of the deadline at the end of 2003, price increases are not attributable to a transition to ethanol production. According to the report, "The early, voluntary phaseout of MTBE by most of California's petroleum industry and the transition to low volatility gasoline do not appear to have been primary causes of the recent high gasoline price divergence in California."

\section{$\underline{\text { ETHANOL NEWS BRIEFS }}$}

\section{Washington State Passes Biodiesel Legislation}

In March, Washington State Governor Gary Locke (D) signed three bills designed to spur the growth of a biodiesel market in Washington State, and another is likely to become law shortly. Introduced by State Rep. Brian Sullivan (D), House Bills 1240, 1241, 1242 and 1243, create tax breaks for biodiesel producers and sellers in Washington, encourage state agencies to use biodiesel fuel, and start a pilot project for using biodiesel in school buses. Biodiesel can be made from an array of feedstocks including mustard seed, recycled vegetable oil, soybeans and used restaurant grease. Studies by the US Department of Energy have shown that biodiesel provides significant cuts in carbon monoxide, carbon dioxide and air toxins when compared to regular diesel. State legislators are hopeful that this could spur the development of a biodiesel market in Washington: "Do we want to lay the groundwork to have this be the center of biodiesel production on the West Coast?" asked Rep. Jeff Morris (D), a supporter of the bills.

\section{Australia to Set 10 percent Limit on Ethanol in Fuel}

In mid-April, the Australian government set a 10 percent limit on ethanol content in petrol gasoline, and issued a requirement to label ethanol blends so that customers know the exact amount of ethanol being used. This is the latest development in a long-running debate in Australia over whether high ethanol levels damage engines. Blends of 20 percent ethanol have been sold in the state of New South Wales since 1994, but initial test results have pointed to engine damage caused by the blends. According to Australian Environment Minister David Kemp, "A 10 percent limit on ethanol blends, combined with mandatory Commonwealth labelling of ethanol blends, will restore confidence in the use of ethanol blends among consumers and industry." The fledgling ethanol industry continues to press the government for a mandate on the use of ethanol blended fuel in order to spur the use and production of ethanol in Australia.

\section{Members of Congress Concerned About Renewable Energy Efficiency Funding}

On April 7, 2003, a "Dear Colleague" letter was sent by a bi-partisan group of 39 House Members to the House Appropriations Committee asking the committee to restore mandatory funding to two grant programs in the 2002 Farm Bill. The Administration's proposed budget eliminates mandatory funding for 
the Value-Added Agricultural Market Product Development Grants program, Section 6401 of the Rural Development title, and The Renewable Energy System and Energy Efficiency Improvements program, Section 9006 of the Energy title. Both these programs provide grants for renewable energy development in the Agricultural sector.

Another "Dear Colleague" was sent to the House Appropriations Interior and Energy and Water Development subcommittees and was signed by a bi-partisan group of Fifty-seven House Members. Led by House Renewable Energy and Energy Efficiency Caucus Co-Chair Mark Udall (D-CO) and ViceChair Vernon J. Ehlers (R-MI), the letter states that new administration programs, such as hydrogen initiatives like the President's FreedomCAR and Fuel Initiative, should not be funded at the expense of ongoing energy efficiency and renewable energy projects. The letter noted that although the $\$ 444$ million request for the Energy Department's Energy Efficiency and Renewable Energy Office (EERE) does represent a $\$ 37$ million increase over FY03, a majority of that funding would be directed toward hydrogen fuel cell development. Biomass, wind and geothermal programs would receive substantial cuts under the President's budget. A group of 14 environmental and business groups sent a similar letter as well.

\section{Cellulosic Ethanol Continues to Break Barriers}

Genencor, a multinational biotechnology company, recently announced that it has met and exceeded its goal of developing an economically viable enzymatic process for converting biomass to ethanol. Genenco was awarded a \$17 million contract with the Department of Energy's (DOE) National Renewable Energy Laboratory (NREL) to achieve a 10-fold improvement in the economics of using enzymes to break down biomass. Unlike starch-based corn ethanol, cellulosic ethanol is generally derived from waste products, and perfecting the enzymatic process has long been considered a necessary hurdle in order to make the production of cellulosic ethanol commercially viable. According to Thomas J. Pekich, vice president of Genencor's Bioproducts group, "The advancement of a cost-effective approach to utilize biomass to produce ethanol and other products is expected to create significant business opportunities."

In another sign of progress towards the commercialization of cellulosic ethanol, Iogen, a privately owned Canadian company, has recently announced that its demonstration facility is now processing 50 tons of wheat straw per week into fermentable sugar. According to Iogen, this amount doubles the plant output from three months ago, and it is now on target to produce over 700,000 liters of ethanol annually. "With every milestone we reach, we are that much closer to seeing EcoEthanol ${ }^{\mathrm{TM}}$ at the pumps," says Iogen President Brian Foody. "The ultimate goal is to develop a product that meets our transportation needs, with a minimal impact on the environment."

\section{USDA Published Bioenergy Program Final Rule}

On May 7, the US Department of Agriculture (USDA) published the final rule for the Commodity Credit Corporation's (CCC) Bioenergy Program in the Federal Register. The rulemaking was undertaken to amend the existing program to fully comply with the 2002 Farm Bill. Sec. 9010 of the Farm Bill calls for the continuation of CCC's Bioenergy Program, which reimburses ethanol and biodiesel producers for the purchase of commodities to expand existing production. The content of the rule includes: "modifying the definitions for biodiesel, eligible commodities, and ethanol; extending the program beyond Fiscal Year (FY) 2002; and allowing producers to enter into multi-year agreements for program payments." For further information, please visit http://www.fsa.usda.gov/daco/bio daco.htm. 


\section{UPCOMING EVENTS}

\begin{tabular}{|c|c|c|c|}
\hline Date & Event & Location & Further Information \\
\hline May 4-7 & $\begin{array}{l}\text { 25th Symposium on } \\
\text { Biotechnology for Fuels } \\
\text { and Chemicals Hosted by } \\
\text { the National Renewable } \\
\text { Energy Laboratory }\end{array}$ & $\begin{array}{l}\text { Breckenridge, } \\
\text { CO }\end{array}$ & $\begin{array}{l}\text { Liz Willson } \\
\text { liz.willson@nrel.gov } \\
\text { 303-284-7750 } \\
\text { http://www.nrel.gov/biotech_symposium/ }\end{array}$ \\
\hline $\begin{array}{l}\text { May } 13 \\
2: 00-3: 30\end{array}$ & $\begin{array}{l}\text { Making Transportation } \\
\text { Cleaner: Innovations and } \\
\text { Policy Opportunities }\end{array}$ & $\begin{array}{l}\text { Washington, } \\
\text { DC (Dirksen } \\
\text { Senate Office } \\
\text { Building 124) }\end{array}$ & $\begin{array}{l}\text { Ray Minjares } \\
\text { rminjares@,eesi.org } \\
202-662--1883\end{array}$ \\
\hline May 14 & Tour de Sol & $\begin{array}{l}\text { Washington, } \\
\text { DC }\end{array}$ & $\begin{array}{l}\text { Nancy Hazard } \\
\text { Nhazard@nesea.org } \\
\text { 413-774-6051 ext. 18 } \\
\text { http://www.nesea.org/tour }\end{array}$ \\
\hline May 21 & $\begin{array}{l}9^{\text {th }} \text { National Clean Cities } \\
\text { Conference and } \\
\text { Exposition }\end{array}$ & $\begin{array}{l}\text { Palm Springs, } \\
\text { CA }\end{array}$ & $\begin{array}{l}\text { (303) } 275-4317 \\
\text { www.ccities.doe.gov }\end{array}$ \\
\hline May 21-22 & $\begin{array}{l}7^{\text {th }} \text { Annual Symposium } \\
\text { Distillers } \\
\text { Grains/Distillery } \\
\text { Operations }\end{array}$ & Louisville, KY & www.distillersgrains.org \\
\hline June 11-13 & $\begin{array}{l}\text { EPAC's } 13^{\text {th }} \text { Annual } \\
\text { Conference }\end{array}$ & Big Sky, MT & $\begin{array}{l}\text { www.ethanolmt.org or email } \\
\text { Shirley@,ethanolmt.org }\end{array}$ \\
\hline June $16-19$ & $\begin{array}{l}\text { 19th's Annual } \\
\text { International Fuel } \\
\text { Ethanol Workshop \& } \\
\text { Trade Show, sponsored } \\
\text { by BBI International } \\
\end{array}$ & Sioux Falls, SD & $\begin{array}{l}\text { 719-942-4353, fax 719-942-4358, e-mail } \\
\text { conferences@bbiethanol.com, or reserve } \\
\text { booth space at } \\
\text { http://www.bbiethanol.com/few }\end{array}$ \\
\hline
\end{tabular}




\section{NOTABLE QUOTABLES}

"The renewable fuels standard is good for the farm and great for America, by encouraging the use of renewable fuels, we help to create more demand for our producers' processed products - which often leads to new ethanol plants, creation of more local jobs, and higher prices for our producers' goods. In addition, a national standard will reduce the U.S. trade deficit by $\$ 34$ billion, reduce government farm payments by $\$ 5.9$ billion over 10 years, and also significantly reduce air pollution."

- U.S. Rep. Tom Osborne (R-NE), April 11, 2003

Writer: Josh Alban

Editors: Carol Werner, Jeremy Ames

Please distribute ECO to your colleagues, or send us their email addresses and we will add them to our distribution list. Article and commentary submissions are encouraged, and should be sent via email.

Environmental and Energy Study Institute

122 C St., NW, Suite 630

Washington DC, 20001

Phone: (202) 662-1885; Fax: (202) 628-1825

eco@eesi.org

Please visit us at http://www.eesi.org/

We welcome your suggestions, comments, and questions. 


\section{Ethanol}

\section{Climate Protection}

Oil Reduction

\author{
A Public Forum \\ Vol. 3, Issue II \\ April 2003
}

Welcome to "ECO." This newsletter is written to provide the most current information about ethanol and serve as a public forum. The Environmental and Energy Study Institute (EESI) hopes to build consensus within the environmental community regarding the potential benefits of ethanol - and particularly the expanded opportunities provided by cellulosic ethanol - with a special focus on climate protection. Ethanol can also be a political bridge to broader alliances in support of climate initiatives.

Many in the environmental community have made strong statements in support of ethanol as a low-carbon fuel with large potential benefits to reduce life-cycle greenhouse gas (GHG) emissions. Ethanol also reduces carbon monoxide emissions and our reliance on oil, contains no sulfur and helps to eliminate smog through its use as an oxygenate for gasoline. Cellulosic ethanol, produced from agricultural wastes, wood wastes or energy crops, provides even greater GHG emission reductions than corn-based ethanol, promotes rural economic revitalization and offers a solution to waste disposal problems. However, there have been concerns about ethanol ranging from volatile organic compounds (VOCs) to corporate welfare. ECO addresses these and other issues. Please share your views with us and we will address them in "ECO."
IN THIS ISSUE:

COMMENTARY: COMMENTARY: Q\&A WITH JEFF PASSMORE, EXECUTIVE VICE PRESIDENT IOGEN CORPORATION...PAGE $\underline{2}$

RENEWABLE FUELS STANDARD REINTRODUCED IN BOTH THE HOUSE AND SENATE... PAGE 4

CONNECTICUT ASSEMBLY CONSIDERS DELAYING MTBE BAN...PAGE

LEGISLATIVE UPDATES:

FUTURE OF ETHANOL TAX SUBSIDY

DEBATED...PAGE 5

PRESIDENT BUSH INTRODUCES

HYDROGEN INITIATIVE...PAGE 6

RECENT STUDIES

"THE FUTURE OF THE HYDROGEN

ECONOMY: BRIGHT OR BLEAK?”...PAGE $\underline{7}$

ETHANOL NEWS BRIEFS ...PAGE 8

UPCOMING EVENTS ...PAGE 9

NOTABLE QUOTABLES ...PAGE 9 


\section{COMMENTARY}

Q \& A with Iogen's Jeff Passmore regarding cellulosic ethanol

ECO recently interviewed Jeff Passmore, Executive Vice President of Iogen Corporation. Iogen is a privately owned Canadian business that has recently announced that its demonstration facility in Ottawa, Canada is successfully processing 30 tons of wheat straw per week into fermentable sugar and is on track to reach annual production of 320,000 liters (roughly 85,000 gallons) of cellulosic ethanol.

Potential feedstocks for producing cellulosic ethanol include a broad range of agricultural residues and forest wastes such as sugar cane bagasse, rice hulls and forest thinnings, municipal wastes such as waste paper, yard waste, construction debris, and industrial wastes such as pulp/paper and sludge. According to research done at the Argonne National Laboratory, cellulosic ethanol also greatly reduces the emission of greenhouse gases when compared to gasoline.

Why does Iogen think the development of a cellulose market is important/desirable?

Iogen's goals include meeting the challenge of reducing North America's greenhouse gas emissions, creating a domestic fuel supply, increasing market opportunities for farmers, and creating local jobs.

Our technology will allow for major impacts on the $\mathrm{CO}_{2}$ put back into the atmosphere in the transportation sector. The demonstration facility in Ottawa, Canada has been designed and engineered to process up to 40 tons of feedstock per day. Currently, the facility is successfully processing 30 tons of wheat straw per week into fermentable sugar - which would produce 320,000 liters of ethanol annually. No one has ever used modern enzyme technology to successfully convert cellulose material (a polymer made up of repeating units of glucose, a simple sugar) such as straw into fermentable sugar on this scale before. The demo plant construction began in 1999 and was commissioned in April of 2002.

\section{What technology is Iogen using in its demonstration facility?}

Iogen Corporation is an industrial manufacturer of enzyme products for the pulp and paper, textiles and animal feed industries, and is a developer of technology to make clean fuels from plant fiber. Since it's founding in the early 1970's, Iogen has been focused on the processing of natural fiber, and has made a substantial commitment to technology in the field. The company's effort has resulted in a range of enzyme products used to improve the way fiber is processed.

EcoEthanol $^{\mathrm{TM}}$ is the same as conventional (or grain derived) ethanol; the difference lies in how it is produced. Our focus for feedstocks has been wheat straw and corn stover - but any cereal straw is useable - as long as the yields make it economical and as long as the cellulose content is there. To be useable in our process, a feedstock must have roughly 60 percent carbohydrate content, and be available in very large quantities such as 750,000 tons per year within an 80 -mile radius. There would also be the question of harvesting the material.

In laymen's terms what happens is that the feedstock, frequently straw, is crushed into a powder. It is then put through a patented pretreatment process to open up the fibers. Enzymes (a natural catalyst used in many industries) are added to the pretreated feedstock. The enzymes break down the cellulose content into sugar. That sugar is then fermented and distilled into ethanol. 
In our process we use the lignin in the straw and stover. It can be used to produce electricity and becomes an integral part of the massive greenhouse gas reductions we see with ethanol from cellulose. On average, one dry metric ton of wheat straw will produce $250 \mathrm{~kg}$ of combustible materials. Of this, approximately $200 \mathrm{~kg}$ is lignin, all of which can be burned to create electricity. Lignin has around 80 percent of the heat content of typical thermal coal, or approximately 20,000 BTU/kg. Depending on the feedstock used and its growing conditions, there can be a surplus of lignin that can be sold to the power grid as green electricity.

\section{What are the greatest technological obstacles to the development of a commercial-scale cellulosic ethanol facility?}

We have always known that you can use enzymes to treat fiber and turn it into sugar; the obstacle lies with at what cost and whether this can be done in an industrial-scale environment. We need supplies of straw, financing, an off-take for the ethanol, a market and an affordable price. Iogen has designed the engineering around the enzyme process, and the enzymes around the engineering process. Our scientists have to keep talking to our processing engineers, and vice versa, in order to come up with the optimal commercial development.

One must also ensure that there is good patent protection in place. Iogen has many patents on our enzymes and stages throughout our EcoEthanol ${ }^{\mathrm{TM}}$ process. Protecting intellectual property is key. We have also not shied away from strategic investments. We realized that we were going to have to give something up to get The Royal Dutch/Shell Group to invest, but you make sure you have smart people on your side of the negotiating table.

\section{What incentives need to be enacted to spur the development of a cellulosic ethanol market?}

Since cellulosic ethanol is in the early stages of commercial development, Iogen would like to see governments willing to discuss with industry how best to further advance the commercialization of this technology. Incentives to fuel the commercialization of this technology may take the form of loan guarantees, capital grants, producer tax credits and/or tax exemptions. We are asking for recognition by the Canadian government of the GHG reduction benefits of Iogen's technology, and a structure to discuss the incentives necessary to establish a cellulose ethanol industry.

\section{Do you see enactment of a national Renewable Fuels Standard (RFS) in the United States as important to achieving your goals?}

While Iogen is a strong supporter of the RFS, the US demand for ethanol will continue to grow due to implementation of state MTBE bans and to increased awareness and acceptance of ethanol in the next three to four years. After that the RFS will allow the market to avoid stagnation.

\section{What are Iogen's next steps if the demonstration plant is a success?}

Iogen has recently signed a \$46 million strategic partnership agreement with The Royal Dutch/Shell Group to aid in the development of Iogen's EcoEthanol ${ }^{\mathrm{TM}}$. The investment will enable Iogen to develop more rapidly the world's first commercial-scale biomass to ethanol plant. While Iogen has not yet made a decision on where the first commercial biorefinery will be built, we are investigating the Canadian prairies, the US Midwest, the UK, and Germany. The first plant should see construction started in late 2004, with EcoEthanol ${ }^{\mathrm{TM}}$ being commercially available in late 2006. 
As always, EESI welcomes your comments about the issues raised in this commentary and throughout ECO. Responses, article and commentary submissions, and feedback can be sent to eco@eesi.org

\section{Renewable Fuels Standard Reintroduced in Both House and Senate}

\begin{abstract}
On February 13 the "Fuels Security Act of 2003" (S. 385) was introduced by Senators Tom Daschle (D-SD), Tim Johnson (D-SD), George Voinovich (R - OH), Richard Lugar (R-IN), and Chuck Hagel (R-NE); a House companion bill (H.R. 837) was introduced by Representatives Collin Peterson (D-MN) and Tom Osborne (R$\mathrm{NE}$ ).
\end{abstract}

S. 385 is nearly identical to a proposal that passed as part of the Senate energy bill last year, but ultimately died when House and Senate conferees were unable to reach agreement on the energy bill. Recent analysis by the US Department of Agriculture (USDA) has suggested that the RFS would create as many as 13,500 jobs and raise net farm income by $\$ 700,000,000$. This was echoed by Sen. Lugar, who stated that "This bill represents an important first step toward reducing our dependence on foreign oil and improving our nation's energy security... at the same time, this proposal goes far toward protecting the environment, stimulating rural economic development and increasing the flexibility of the national fuel supply to reduce the impact of future price spikes."

S. 385 establishes a national Renewable Fuels Standard, requiring the use of five billion gallons of renewable fuels a year by 2012. It would also award credits to US refiners, blenders, distributors or importers that use a greater quantity of renewable fuels (ethanol, biodiesel) than required by law, which could then be sold to other companies to meet their targets. Finally, S. 385 also allows 1 gallon of cellulosic ethanol to be credited as 1.5 gallons of renewable fuel, as an incentive to spur the development of cellulosic ethanol facilities.
S. 385 "markup" by the Senate Environment and Public Works Committee is scheduled for April 9. The bill also mandates the elimination of MTBE as a fuel oxygenate and creates a "safe harbor" provision to exempt renewable fuels producers from certain product liability claims. Minority Leader Sen. Daschle and co-sponsor Sen. Voinovich (R-OH) have stated their intent to keep the measure from being wrapped into a larger, comprehensive energy package, so that it would move as a free-standing bill and not have its fate tied to a large energy bill as occurred last year.

The Energy Policy Act of 2003 passed out of the House Energy and Commerce Committee on April 3. Chairman Tauzin (R-LA) and Subcommittee Chairman Barton (R-TX) included their own version of a RFS in this comprehensive energy bill, rather than H.R. 837. Similar to its Senate counterpart, the House bill eliminates the oxygenate requirement of the 1990 Clean Air Act, but unlike the Senate bill it does not ban MTBE. An amendment offered by Rep. Lois Capps (D-CA) to ban MTBE failed by 18-32, meaning that the banning of the controversial fuel additive would continue on a state-by-state basis. (In recognition of this trend, the House bill and S. 385 will provide transition grants for the MTBE industry.) The House legislation would also extend the Senate's "safe harbor" provision to MTBE producers, which could prove controversial in conference with the Senate. The House bill sets the five billion gallon requirement at 2015. Also rejected (1431) was an amendment from Energy and Air Quality Subcommittee ranking member Rick Boucher (D-VA) which would have stripped the RFS from the bill. The bill could come to the House floor by next week, as House Majority Leader Tom DeLay (R-TX) has promised to move an energy package before spring recess begins (April 11). 


\section{Connecticut Assembly Considers Delaying MTBE Ban}

On March 17, the Environment Committee of the Connecticut General Assembly approved moving the state's MTBE ban to January 1, 2004. The bill will now go to the House and Senate for final approval. Doing so would coincide with New York's deadline for banning MTBE. The ban was originally mandated in a 2000 bill that called for the removal of the controversial gasoline additive by October 1 , 2003.

Connecticut officials from the Department of Environment Protection (DEP) agree that MTBE must be removed from gasoline, but have expressed concerns about the risks of relying upon ethanol as the sole oxygenate in Connecticut gasoline. After meetings with gasoline suppliers, a DEP source stated that the requisite amount of ethanol could not be imported from the Midwest by the deadline, and also expressed fear of a possible gas price spike that could result from having to import the fuel additive.

New York's ban may ultimately depend on the outcome of a request to the EPA for an exemption from the federal oxygenate requirement in the area surrounding Manhattan. New York State officials argued that replacing MTBE with ethanol would prove too costly for oil producers who will be forced to import the ethanol from out-of-state producers. Furthermore, state officials have objected to implementing MTBE bans on a state-to-state basis: "The only way to develop a consistent region wide approach to RFG or any fuels is for the federal government to establish the standards," says Dan Gilbert of the New York State Department of Environmental Conservation. A meeting to discuss the request with EPA staff and state officials has not been arranged as of yet, but will take place shortly.

California made a similar waiver request, which was rejected by EPA in June, 2001. Governor Gray Davis (D) responded by delaying the states MTBE phase-out by one year until December
31,2003 . In 2002, the state burned 100 million gallons of ethanol and 1.5 billion gallons of MTBE. By the end of this year, the state will use six times that much ethanol and far less MTBE.

\section{LEGISLATIVE UPDATES}

\section{Future of Ethanol Tax Subsidy Debated}

On April 2, the Senate Finance Committee, chaired by Sen. Grassley (R-IA) has approved more than $\$ 15$ billion in energy tax incentives that could have significant implications for renewable energy use and production. In addition to providing a host of energy incentives to renewable and non-renewable energy sources, a little-noted change to the bill in the chairman's mark redirects all revenue derived from the ethanol excise tax to the Highway Trust Fund, as an attempt to augment Highway Trust Fund revenue. Currently, 2.5 cents of the 18.4-cent tax on ethanol is put in the general treasury.

The ethanol subsidy, first established in The Energy Security Act of 1979, was intended to reduce American dependence on oil imports. To help spur this, the law provides for a partial federal excise tax exemption in prescribed portions with ethanol. The tax break currently stands at 5.2 cents on 10 percent ethanol blends and is scheduled to be reduced to 5.1 cents in 2005, and expire December 31, 2006.

Amendments to the 1990 Clean Air Act required the blending of ethanol as a fuel oxygenate to reduce vehicle's smog-causing emissions. This requirement, along with the tax break, has helped to grow the market for ethanol.

Yet critics have argued that ethanol's increasing use effectively means that more funds are being diverted from the Highway Trust Fund, which depends on the excise tax as a revenue stream. Critics such as Senator James Inhofe (R-OK), Chairman of the Committee on Environment and Public Works, have repeatedly called for the repeal of the ethanol tax break. In a February speech to the U.S. Chamber of Commerce, Sen. 
Inhofe claimed that eliminating the federal tax break on ethanol could boost highway funding by nearly $\$ 3$ billion in FY04 and more than $\$ 19$ billion over the next six years. While Sen. Inhofe has introduced no legislation to this effect, it clearly remains an option. House Transportation Committee Chairman Representative Don Young (R-AK) seems to share this view and has proposed eliminating the ethanol subsidy.

Thus, directing all of ethanol's excise tax revenue to the Highway Trust Fund represents somewhat of a middle ground. Proponents argue that it represents a "win-win" situation because it does not threaten the long-term health of the ethanol industry, while at the same time boosting much needed revenue to the Highway Trust Fund. Ranking member of the Senate Finance Committee, Sen. Baucus has said, " I expect the use of ethanol-based fuels to continue to increase as we continue to search for energy alternatives... We need to explore every avenue to make sure our highways have enough funding to be maintained and enhanced."

The House energy tax bill (H.R. 1531) finished bill markup April 3 in the House Ways and Means Committee. It does not attempt to redirect the ethanol tax credit.

\section{President Bush introduces Hydrogen Initiative}

The House Science Committee has approved H.R. 238, a bill that includes $\$ 325$ million for FY04 for President Bush's Hydrogen Initiative and "FreedomCar" programs. The bill authorizes $\$ 1.7$ billion over the next five years, matching the request made in his State of the Union address in which he explained his vision for the development of a hydrogen economy.

Replacing the internal combustion engine with a clean-burning hydrogen fuel cell has long been embraced by the environmental and scientific community as a tool for oil displacement and climate change mitigation. However, actually releasing the hydrogen from chemical compounds that contain it has proven challenging, and progress is still very much in the research phase. According to Bush, the legislation is designed to accelerate fuel cell and hydrogen research with the hopes of having hydrogen-powered cars by 2020: "Our scientists and engineers will overcome obstacles to taking these cars from laboratory to showroom, so that the first car driven by a child born today could be powered by hydrogen, and pollution-free."

While many applaud Bush's vision of a hydrogen-based transportation sector, some remain skeptical about the plan. Jason Mark, Director of the Clean Vehicles Program for the Union of Concerned Scientists argues, "while fuel cells hold tremendous promise to transform transportation, it will take time to deliver on that promise. With oil use increasing at alarming rates, President Bush should aggressively push conventional technologies that can deliver costeffective savings today - as opposed to waiting two decades." By placing such an outright emphasis on hydrogen as an alternative fuel of the future, some fear that the President is implicitly overlooking measures and technologies that are available today. Increasing fuel efficiency and expanding the use of biofuels offer promising ways to encourage oil displacement and reduce carbon dioxide emissions. Critics fear over-stressing the importance of hydrogen effectively ignores current methods and fuels that will be necessary until hydrogen becomes a viable option.

The way in which hydrogen is produced is also of concern. President Bush has commented on the need for producing hydrogen from multiple sources: "First, the hydrogen can be produced from domestic sources -- initially, natural gas; eventually, biomass, ethanol, clean coal, or nuclear energy. That's important. If you can produce something yourself, it means you're less dependent upon somebody else to produce it." Yet, according to the Department of Energy, 96 percent of hydrogen produced in the world today comes from natural gas, oil and coal - all fossil fuels that contribute to climate change and damage public health. Indeed, a senior administration official stated that, "Initially, we anticipate that the source of the hydrogen fuel in 
this country would be natural gas." The danger here, critics point out, is that a reliance on fossil fuels in the production of hydrogen could actually offset environmental gains made by fuel cell technology.

To avoid such a case, many would like to see hydrogen produced by renewable sources of energy such as wind energy, solar energy, or biomass and DOE investment/roadmap plans that lead in that direction. According to NREL, biomass could be used to supply hydrogen for use in 40 percent of current U.S. light-duty vehicles by 2020 were they using fuel cell technology and 20 percent if they were using internal combustion engines burning hydrogen. NREL also compared greenhouse gas emissions of hydrogen production using natural gas versus a biomass feedstock such as switch grass, and found that $\mathrm{CO}_{2}$ emissions are significantly reduced when relying on biomass in the production process.

Still, others are critical of how the program is being funded. Although the Office of Energy Efficiency and Renewable Energy's total budget is essentially unchanged from FY03, most existing programs face cuts to pay for the administration's new hydrogen and fuel cell research program. The biomass research program, which funds research on biofuels, bioenergy, and biobased product research, faces a 28.5 percent cut from FY2003, with a request of $\$ 78.5$ million for FY04.

Apart from these concerns, many groups have applauded the President's proposal as a first step in the right direction.

\section{RECENT STUDIES}

\section{The Future Of The Hydrogen Economy: Bright Or Bleak?}

In the preliminary results of a study to be entitled "The Future Of The Hydrogen Economy: Bright Or Bleak?" Switzerland-based researchers Baldur Eliasson and Ulf Bossel discuss the plausibility of a future "hydrogen based economy." Eliasson heads the Energy and Global Change Program for ABB, a multinational power and automation technology company, and Bossel is a free-lancing fuel cell consultant with clients in Europe, Japan and the U.S. They argue that the hydrogen economy will not and cannot consist of the production and use of hydrogen alone. Because of the physical properties of hydrogen itself, the researchers claim that the gas is not compatible with the requirements of the energy market. Specifically, the packaging, storage, delivery and transferring of hydrogen are all energy intensive exercises. The problem here, according to Eliasson and Bossel, is that in order for a hydrogen economy to truly work, the amount of energy going into these logistical challenges must be less than the amount of energy delivered to the end-user.

For example, hydrogen does not exist in nature in its pure state, but rather, must be produced usually from water and natural gas. This process requires energy, and in order for the production process to remain "clean," the electricity required to do so must come from a clean source. The cleanest option here is hydrogen production through electrolysis, which is currently much more expensive than using fossil fuels such as coal and natural gas. Over time this may even out, but as technology stands right now, Eliasson and Bossel hold that fossil fuels are the most likely candidates to power hydrogen production.

Once the hydrogen is produced, complications arise in preparing the gas for transfer, which includes the actual "packaging" of the fuel, as well as the transport of the fuel. It is possible to compress hydrogen for transport purposes, or convert hydrogen into its liquid form, but both of these options are energy intensive.

Actual transportation of the hydrogen also presents challenges. Assuming a hydrogen economy would involve some transport of hydrogen by trucks, Eliasson and Bossel make note that the road delivery of hydrogen is highly energy intensive when compared to other gases like methanol, propane, or methane: "A midsize filling station on any frequented freeway 
easily sells 25 tons of fuel each day. This fuel can be delivered by one 40-ton gasoline truck. But it would need 21 hydrogen trucks to deliver the same amount of energy to the station..." Nor is transporting hydrogen through pipeline energy efficient. Because of the low energy density of hydrogen, the flow velocity in the pipe itself must be increased by over three times; the result is that 4.6 times more energy would be required to move hydrogen through the pipeline than with natural gas, a fossil fuel.

For Eliasson and Bossel, these difficulties do not mean that a hydrogen economy is an impossibility, they simply think that hydrogen alone will not be the only component in a future hydrogen economy. Generally speaking, they envision hydrogen being most useable where the end-user is relatively close to production location: "hydrogen may be the only link between physical energy from renewable sources and chemical energy... But hydrogen is not the ideal energy carrier between primary sources and distant end users." The ideal energy carrier, according to Eliasson and Bossel, would be a liquid fuel, including alcohol-based fuels (ethanol and methanol, etc). They conclude that biomass-derived methanol would be the most viable option.

\section{$\underline{\text { ETHANOL NEWS BRIEFS }}$}

\section{Minnesota cuts ethanol program}

In an effort to address Minnesota's $\$ 4.2$ billion shortfall for FY03, Governor Tim Pawlenty cut Minnesota's ethanol program from \$27 million to \$6 million. This means that instead of receiving a 20 cent per gallon credit each fiscal quarter, ethanol plants will receive 20 cents per gallon for the first quarter, 15 cents for the second quarter and no credit for the third and forth quarters. Although state legislators had decided not to eliminate the program, the state Senate voted to trim the program by $\$ 3$ million and the state House voted to cut roughly $\$ 5$ million. Ultimately, when the state Senate and House were unable to agree on cost-cutting measures, Gov. Pawlenty was forced to make a decision. Not surprisingly, the Minnesota ethanol community has expressed concern over the effect these cuts will have on local economies: "This is not some sort of subsidy for affluent farmers... this is an incentive for investment in rural Minnesota and must be viewed in that context," said Bill Lee, Chippewa Valley Ethanol Company general manager and spokesman for the Minnesota Ethanol Coalition.

\section{Environmentalists to include ethanol in California GHG Law}

The Blue Water Network, a non-governmental organization based in San Francisco, will propose that ethanol be used in order to help California meet its newly required greenhouse gas emissions. AB 1493, signed into law in July 2002 by Governor Grey Davis, requires the California Air Resources Board (CARB) to adopt regulations to control GHG emissions from cars and trucks by January 1, 2005. The Blue Water Network, which helped craft the legislation, argues that CARB is far too focused on curbing tailpipe emissions, disregarding the need to address greenhouse gas emissions during the fuel production process. Whereas petroleum gasoline draws its energy from fossil fuels that are, for all practical purposes, not part of the "carbon cycle," the feed stocks used for ethanol production - mainly plant matter - are already part of the carbon cycle. Therefore, at least in the terms of feedstocks, ethanol production contributes no net $\mathrm{CO}_{2}$ emissions to the carbon cycle.

However, in order to encourage this benefit, the state will have to provide production incentives to help producers gain a foothold in the California market. Proponents argue that doing so would not only help the state meet its newly established GHG standards, but would also ensure the existence of a stable ethanol industry in the state. In anticipation of implementation of the state's MTBE ban of Jan 1, 2004, 
nearly all of California's refiners have already begun blending ethanol with conventional gasoline. The state is expecting to blend roughly 800 million gallons per year.

\section{EESI hosts briefing on Renewable Fuels Standard legislation}

On Thursday, March 27, The Environmental and Energy Study Institute (EESI) hosted a Congressional briefing on recently introduced legislation to establish a Renewable Fuels Standard (RFS). An expert panel of speakers provided an overview of the proposed RFS legislation, and examined its potential energy supply, economic development, and environmental quality implications. The briefing panel included US Congressman Gil Gutknecht (R-MN); Michael Whatley, Staff Director, Senate Subcommittee on Clean Air, Climate Change and Nuclear Safety; Ken Colburn, Executive Director, Northeast States for Coordinated Air Use Management; Dan Dorman, Member of the Minnesota House of Representatives; Alice Durkee, Vice President, Masada Resource Group; and Dr. Edward Murphy, Downstream Manager, American Petroleum Institute. For more information on the briefing, including the speakers' presentations, visit http://www.eesi.org/briefings/brief.htm.

\section{R\&D Solicitation}

The U.S. Department of Agriculture and the U.S. Department of Energy jointly announce the availability of funds and solicit proposals for a grant under the Biomass Research and Development Act of 2000 and other authorities. Federal policy supports greater use of biomass based products, biomass feedstock production, and biomass processing and conversion. This solicitation for proposals is intended to promote greater innovation and development related to biomass. Schedule: Proposals due May 16, 2003 http://www.bioproducts-bioenergy.gov/pdfs/BiomassRFP2003.pdf 


\section{UPCOMING EVENTS}

\begin{tabular}{|c|c|c|c|}
\hline Date & Event & Location & Further Information \\
\hline April 14-15 & $\begin{array}{l}\text { DOE Ethanol Workshop } \\
\text { Series: California } \\
\text { Ethanol Workshop, } \\
\text { Developing Ethanol's } \\
\text { Role in California's } \\
\text { Energy, Economic \& } \\
\text { Environmental Future } \\
\text { With support from the } \\
\text { California Energy } \\
\text { Commission, California } \\
\text { Dept. of Food and } \\
\text { Agriculture, California } \\
\text { Farm Bureau, California } \\
\text { Renewable Energy } \\
\text { Partnership, and Cal. } \\
\text { State University - Fresno }\end{array}$ & $\begin{array}{l}\text { Sacramento, } \\
\text { CA }\end{array}$ & $\begin{array}{l}\text { Embassy Suites Hotel } \\
\text { 100 Capitol Mall } \\
\text { Sacramento, CA 95814 } \\
\text { Reservations: (916) 326-5000 } \\
\text { http://www.bbiethanol.com/doe/ }\end{array}$ \\
\hline May 4, 2003 & $\begin{array}{l}\text { 25th Symposium on } \\
\text { Biotechnology for Fuels } \\
\text { and Chemicals Hosted by } \\
\text { the National Renewable } \\
\text { Energy Laboratory }\end{array}$ & $\begin{array}{l}\text { Breckenridge, } \\
\text { CO }\end{array}$ & $\begin{array}{l}\text { Liz Willson } \\
\text { liz.willson@nrel.gov } \\
\text { 303-284-7750 } \\
\text { http://www.nrel.gov/biotech_symposium/ }\end{array}$ \\
\hline $\begin{array}{l}\text { May 14, } \\
2003\end{array}$ & Tour de Sol & $\begin{array}{l}\text { Washington, } \\
\text { DC }\end{array}$ & $\begin{array}{l}\text { Nancy Hazard } \\
\text { Nhazard@nesea.org } \\
\text { 413-774-6051 ext. } 18 \\
\text { http://www.nesea.org/tour }\end{array}$ \\
\hline June 16-19 & $\begin{array}{l}\text { 19th's Annual } \\
\text { International Fuel } \\
\text { Ethanol Workshop \& } \\
\text { Trade Show, sponsored } \\
\text { by BBI International }\end{array}$ & Sioux Falls, SD & $\begin{array}{l}\text { 719-942-4353, fax 719-942-4358, e-mail } \\
\text { conferences@bbiethanol.com, or reserve } \\
\text { booth space at } \\
\text { http://www.bbiethanol.com/few }\end{array}$ \\
\hline
\end{tabular}




\section{NOTABLE QUOTABLES}

"We need a policy that broadens our base of energy resources to create stability, guarantee reasonable prices, and protect America's security.... Given the current situation in the Middle East, perhaps our greatest energy challenge is to reduce our reliance on foreign sources to meet our energy needs... It is crucial that we become less dependent on foreign sources of oil and look more to domestic sources to meet our energy needs. Ethanol is an excellent domestic source - it is a clean burning, homegrown renewable fuel that we can rely on for generations to come."

- Sen. George Voinovich (R- OH), Senate Committee on Environment and Public Works Hearing on Fuel Additives and Renewable Fuels, March 20, 2003

Writer: Josh Alban

Editors: Carol Werner, Jeremy Ames

Please distribute ECO to your colleagues, or send us their email addresses and we will add them to our distribution list. Article and commentary submissions are encouraged, and should be sent via email.

Environmental and Energy Study Institute

122 C St., NW, Suite 630

Washington DC, 20001

Phone: (202) 662-1885; Fax: (202) 628-1825

eco@eesi.org

Please visit us at http://www.eesi.org/

We welcome your suggestions, comments, and questions. 


\section{Ethanol}

\section{Climate Protection}

Oil Reduction

\author{
A Public Forum \\ Vol. 3, Issue I \\ February 2003
}

Welcome to "ECO." This newsletter is written to provide the most current information about ethanol and serve as a public forum. The Environmental and Energy Study Institute (EESI) hopes to build consensus within the environmental community regarding the potential benefits of ethanol - and particularly the expanded opportunities provided by cellulosic ethanol - with a special focus on climate protection. Ethanol can also be a political bridge to broader alliances in support of climate initiatives.

Many in the environmental community have made strong statements in support of ethanol as a low-carbon fuel with large potential benefits to reduce life-cycle greenhouse gas (GHG) emissions. Ethanol also reduces carbon monoxide emissions and our reliance on oil, contains no sulfur and helps to eliminate smog through its use as an oxygenate for gasoline. Cellulosic ethanol, which is produced from agricultural or wood wastes, provides even greater $G H G$ emission reductions than corn-based ethanol, promotes rural economic revitalization and offers a solution to waste disposal problems. However, there have been concerns about ethanol ranging from volatile organic compounds (VOCs) to corporate welfare. ECO addresses these and other issues. Please share your views with us and we will address them in "ECO."

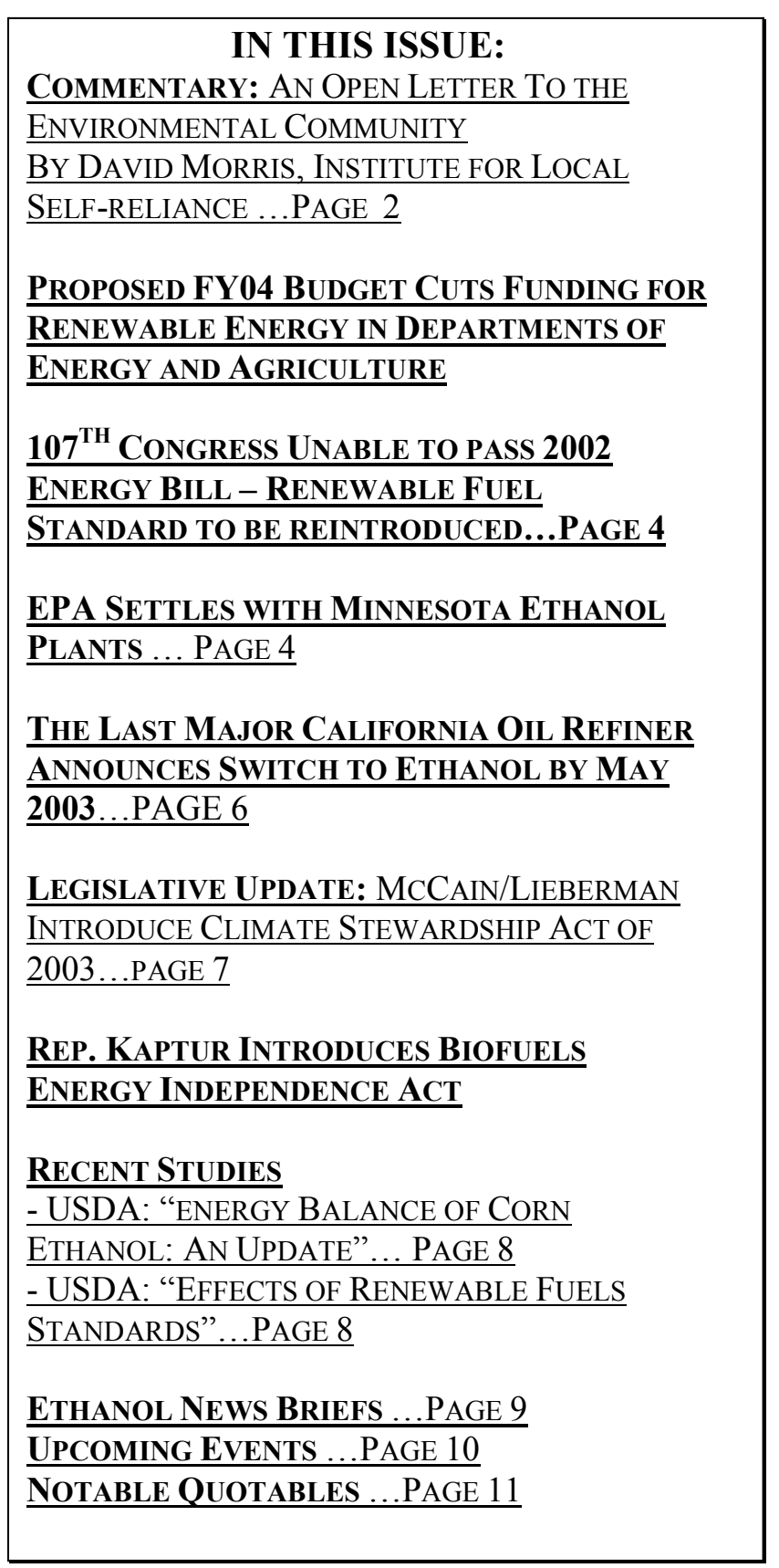




\section{COMMENTARY \\ An Open Letter to the Environmental Community By David Morris, Institute for Local Self-Reliance}

Ethanol is the fuel environmentalists love to hate. After a decade of discussing the issue with my brethren in the environmental community, I'm bewildered by the continuing unreflective opposition of some. I understand the antagonism from those with an apocalyptic vision of the future. David Pimentel, for example, has written that nearly 80 percent of the planet's population will have to disappear to allow the remainder sufficient biological resources to survive in comfortable fashion. He and others who forecast mass starvation reasonably enough recommend that every acre be used to grow food for humans. Feeding crops to animals itself is suspect. Using plants to generate energy is taboo.

I disagree with their dismal prognosis but I understand their logic.

The virulent opposition to ethanol from those with a less apocalyptic vision of the future is more perplexing. Some say it is because ethanol is now made from corn, but they aren't opposed to corn chips or corn flakes. Some say it is because ethanol is not a perfect fuel. But every energy source has its drawbacks, a fact the environmental community appears to recognize when it evaluates other fuels.

Indeed, one might expect ethanol to be given a little leeway. After all, it is alcohol - a single chemical that the body, or at least the mind, enjoys imbibing. Gasoline, on the other hand, is a chemical stew of several hundred highly toxic materials. Yet it is these chemicals, not ethanol, that tend to get the benefit of the doubt from environmentalists.

By way of example, when MTBE was on the way to constituting more than 10 percent of California's and 3 percent of the nation's automobile fuel supply, environmentalists appeared unconcerned that the net energy equation of MTBE was decidedly negative. They appeared equally unconcerned that one or two global corporations dominated the MTBE industry. Yet the controversy over just how positive is the net energy of ethanol and the dominant role ADM plays in the ethanol industry continues to rage.

Even when MTBE was found to cause widespread water contamination, many in the environmental community were measured in their response. One report by a prominent New England coalition of environmental and business groups concluded that, when all the costs and benefits were included, MTBE was an acceptable fuel. It argued, "The aggregate public health benefits RFG provides by reducing air pollution substantially outweigh potential adverse public health impacts from exposure to increased levels of MTBE in the air and water."

But with ethanol, this measured cost/benefit based approach is less evident. Recently, for example, we were involved in an exchange with a prominent member of a national environmental organization. He had been sent our paper examining the net energy of ethanol (www.newrules.org/agri/). He found the report "unpersuasive" because the excess of energy produced over fossil fuel energy consumed was modest.

We then asked him two questions. First, given that the study identified a 38 percent net energy benefit based on the national average of energy used on farms and in ethanol facilities in 1995 and a 100 percent net energy benefit (two units of energy out for every unit of energy in) for 1995 "best practices", a better indicator of the average net energy figure for 2002, what would he consider a "persuasive" net energy increase?

Second, what is the net energy equation for fuels and technologies that his group supports, like on-board reforming of natural gas into hydrogen for fuel cells or electrolyzing water for making hydrogen? 
He was unable or unwilling to answer these questions.

Two years ago environmentalists and ethanol advocates met in Washington, D.C. to thrash out their differences and work together on federal legislation phasing out MTBE. One of the disputes at the meeting related to ethanol's impact on air quality, specifically on ozone formation. At the end of the meeting participants agreed to share scientific and economic information that supported their different points of view. ILSR sent a paper citing scientific studies that argued that ethanol's impact on ozone formation was trivial. The environmental representatives offered no studies.

Last year, ILSR requested epidemiological data that support the California Air Resources Board's (CARB) position that the public health impact of ethanol blends is significantly harmful. Our staff epidemiologist identified a number of studies that found the negative health impact of ozone to be modest and reversible. Several senior officials at CARB responded to our request by simply repeating their contention that ethanol blends increase gasoline's volatility, a contention with which we did not disagree. They were unable or unwilling to provide studies that support their position.

This refusal to engage hurts both sides because it prevents us from working together to develop win-win strategies. For example, if public health studies should indicate that higher emissions of volatile organic compounds from ethanol blends are a problem, we could and should require oil refineries to lower the base volatility of gasoline. A number of oil companies already make such gasoline. EPA estimates the cost would be 1-2 cents per gallon. The result would be to allow a 10 percent ethanol blend without raising VOC emissions at all.

When it comes to transportation, we agree with environmentalists that improved vehicle efficiency is the best strategy. Yet even the most efficient vehicles will need fuels. Hydrogen may be the best long-term solution, but for the next few decades we will be relying on liquid fuels. Moreover, carbohydrates may be a better source of hydrogen in the long term than either hydrocarbons or water.

Every fuel source, including wind turbines and solar cells, has tradeoffs. When the wind energy industry first expanded there was a problem with bird kills. Large wind turbines can be visually intrusive. Solar cell manufacturing uses toxic chemicals.

Yet these drawbacks have not dampened environmentalists' enthusiasm for these energy sources. Why not bring the same full-cost accounting attitude to the ethanol debate?

A vigorous dialogue over the future of our transportation energy supply is essential. We may never get to yes. But we should be able to know where we disagree and why.

As a start, we could have a place where interested parties can go to review the positions and the supporting studies of all sides. ILSR would be glad to provide the host site. Or perhaps one of the nation's leading environmental organizations would take on this role?

David Morris (dmorris@ilsr.org)

Vice President

Institute for Local Self-Reliance

This letter originally appeared in the Carbohydrate Economy Newsletter, Summer 2002 Edition. See http://www.ilsr.org/ for more info.

As always, EESI welcomes your comments about the issues raised in this commentary and throughout ECO. Responses, article and commentary submissions, and feedback can be sent to eco@eesi.org 


\section{Administration's Proposed FY04 Budget Cuts Funding for Renewable Energy in Departments of Energy and Agriculture}

On February 3, 2003 the Bush administration released its proposed budget for Fiscal Year 2004 (FY04). The U.S. Department of Agriculture's (USDA) budget proposes cuts in both the new grants and loans program within the energy title passed as part of the Farm Security and Rural Investment Act of 2002 (H.R. 2646), and the existing Value-Added grants program. The Department of Energy's bioenergy research program was also cut substantially.

\section{The Renewable Energy System and Energy} Efficiency Improvements program, as part of the new energy title to the 2002 Farm Bill, was to receive $\$ 23$ million a year in mandatory (non-discretionary) funds to provide grants and loans to farmers, ranchers, and rural small businesses for the development of renewable energy projects and energy efficiency improvements. However, the administration's budget proposes spending $\$ 18$ million on the program in FY03 (a cut of $\$ 5$ million), but proposes to utilize no mandatory funds for FY04. Instead, USDA requests only $\$ 3$ million in discretionary funds for the program in FY04, representing a $\$ 20$ million cut from Congressionally approved levels. "The bottom line is that when it comes to the agriculture budget, just like many other issues, the president's words do not match his actions," said Senator Tom Harkin (D-IA), the program's key author.

The Rural Business-Cooperative Service has been working to implement the program, and plans to issue a Notice of Funding Availability this spring to award FY03 funds. The budget also proposes a $\$ 100$ million annual cap on the Commodity Credit Corporation's Bioenergy Program, which reimburses producers of ethanol and biodiesel for the purchase of commodities to expand existing production. Among the energy title's other mandatory programs, the Federal Procurement of Biobased Products program (Sec. 9002), the Biodiesel Education Program (Sec. 9004), and the Biomass Research and Development Initiative (Sec.9008) did not appear to be in jeopardy of cuts. USDA did not request funding for any of the energy title's discretionary programs, including the Biorefinery Development Grants program (Sec. 9003) or the Energy Audit and Renewable Energy Development Program (Sec. 9005), so it is unlikely they will be carried out in FY04 unless Congress provides funding.

In addition, the Value-Added Agricultural Product Market Development Grant was reauthorized in the Rural Development title of the Farm Bill, and provided $\$ 40$ million a year in mandatory funding. The program was created to spur development of new uses for agricultural products, and the 2002 Farm Bill amended the program to include renewable energy. In 2002, several grants were awarded to ethanol projects throughout the country (see News Briefs). The administration's FY2004 budget proposes to utilize no mandatory funds for 2004, and requests $\$ 2$ million in discretionary funds, effectively a $\$ 38$ million cut from Congressionally approved levels. USDA expended only $\$ 10$ million in mandatory funds in 2003, as unspent money from previous year was carried over - this represents an additional $\$ 30$ million cut for this program. Essentially, the administration is proposing a cut of $\$ 68$ million in this program over two years when Congress has called for $\$ 80$ million in mandatory funding in that period. Iowa's other senator, Sen. Charles Grassley (R-IA) responded, "I fought hard for this program three years ago, and I'll work to get it funded this year," Grassley said. "It can help family farmers capture a greater share of the consumer food dollar by fostering development of new business opportunities for the independent producer."

The administration's budget also proposes a large cut for the biomass program within the Department of Energy's Office of Energy Efficiency and Renewable Energy (EERE). The biomass program funds research on biofuel, 
bioenergy, and biobased product development. The administration requests $\$ 78.5$ million for the program in FY04, a 28.5 percent cut from its FY2003 request. Although EERE's total budget is essentially unchanged from FY2003, most established programs face cuts to pay for the administration's new hydrogen fuel cell research program, announced in President Bush's State of the Union address last month. The next step will be for Congress to respond to the proposed budget.

\section{$107^{\text {th }}$ Congress Unable to pass 2002 Energy Bill - Renewable Fuel Standard (RFS) To be reintroduced}

United States House and Senate conferees were unable to reach agreement on a comprehensive energy bill before the clock ran out on the $107^{\text {th }}$ Congress. Although both the House and Senate passed energy legislation, members of the conference committee were unable to reconcile the two bills before the end of the session. The Senate's bill (S.517) included an agreement to ban the fuel additive MTBE, the elimination of the federal oxygenate requirement for reformulated gasoline, and the establishment of a national Renewable Fuels Standard (RFS) for motor vehicle fuels.

Despite criticism from the New York and California senators, the RFS passed with broad bipartisan support. The proposed RFS was seen by many as groundbreaking legislation for renewable fuels. It would have ensured the use of 5 billion gallons of biofuel (ethanol and biodiesel) by 2012 in the United States fuel market. It also would have credited 1 gallon of cellulosic ethanol as 1.5 gallons of renewable fuel, as an incentive to spur the development of waste-to-ethanol facilities (See Recent Studies).

Recent analysis by the United States Department of Agriculture (USDA) had suggested that the RFS would have created as many as 13,500 jobs and raised net farm income by $\$ 700,000,000$.

Proponents of the RFS appear confident about their prospects in the $108^{\text {th }}$ Congress. According to Tom Hume, chairman, National Corn Growers Association (NCGA), "The groups that supported a renewable fuels standard are still in place...Just because Washington doesn't have its act together doesn't mean people will start walking away from it." Indeed, nearly all key Senate supporters of the RFS will be returning to Capitol Hill in the $108^{\text {th }}$ Congress. Although the House did not include an RFS in its bill, the idea seems to have increasing support in the Energy and Commerce committees. House conferees had offered an RFS agreement, which was rejected by the Senate conferees due to disagreement on a MTBE liability waiver.

Several Senators from both parties, including Minority Leader Tom Daschle (D-SD), are expected to reintroduce RFS legislation in the next month.

\section{US EPA ANNOUNCES SETTLEMENT WITH MINNESOTA ETHANOL PLANTS}

In October 2002, the United States

Environmental Protection Agency (US EPA), the Department of Justice, and the State of Minnesota announced that they had reached civil settlements with 12 Minnesota-based ethanol plants. The plants were accused of violating a section of the "New Source Review" provision of the 1990 Clean Air Act. Under the provision, if sources are found to be emitting above legal levels, they are required to assume all costs associated with the purchase and installation of appropriate pollution control equipment in order to come into attainment levels. In the case of the 12 Minnesota plants, the terms of the civil settlement require the installation of equipment called thermal oxidizers, an apparatus designed to reduce emissions of volatile organic compounds (VOC's) and carbon monoxide (CO). The equipment will also lessen emissions of nitrogen oxides (NOx), particulate matter $(\mathrm{PM})$, and hazardous air pollutants. The purchase and installation of the oxidizers are estimated to cost roughly $\$ 2$ million per plant, and will come in addition to a civil penalty ranging from $\$ 29,000$ - $\$ 39,000$ per facility.

The settlements were the conclusion of an investigation dating back to May 2002, after 
EPA officials noticed data suggesting excessive emission levels among Minnesota's ethanol plants. Because this was the first time that ethanol producers had been investigated for Clean Air Act violations, the process served as somewhat of a litmus test for interaction between ethanol producers and federal and state enforcement agencies. According to government officials, interaction with the ethanol industry has thus far been positive: "This is a success story for everyone involved and a sign of continued progress with the ethanol industry. These companies are to be commended for working cooperatively with state and federal officials to achieve compliance," said Tom Sansonetti, assistant attorney general for the Justice Department's Environment and Natural Resources Division.

As EPA and Justice Department officials were announcing the settlements, the Sierra Club announced its intention to file suit against two Midwestern ethanol plants - one of which is located in Minnesota. The Sierra Club charges that based on EPA data, the plants are emitting far more pollutants than legally permitted, and that the government should be pursuing enforcement action against the plants. "There's a clear pattern in this industry of systematic disregard for the law...these lawsuits should serve as a warning to the entire industry to clean up their act, and to the EPA to enforce the law," said Sierra Club attorney David Bookbinder. At the time of this printing, no official lawsuits have been filed by the Sierra Club.

\section{LAST MAJOR CALIFORNia OIL REFINER ANNOUNCES TRANSITION FROM MTBE TO ETHANOL}

ChevronTexaco Corp. announced in January that it would make the transition from blending MTBE to blending ethanol in its gasoline in Southern California by May 2003. It was the last of the major refiners in California to commit to phasing out MTBE before the December 31 2003 state deadline, joining ExxonMobil, British Petroleum, Shell Oil, and Phillips Petroleum.
The 1990 Clean Air Act requires either MTBE or ethanol to be blended with gasoline in order to improve regional air quality. But when MTBE began showing up in groundwater supplies, California Governor Gray Davis ordered that MTBE be phased out of gasoline blends by Dec 2002. However, controversy ensued when both the public and private sector expressed concerns about the risks of relying upon ethanol as the sole oxygenate in California gasoline.

Specifically, doubts were expressed as to the availability of the anticipated 580 million gallons of ethanol that would be needed in the state and the effects the transition might have on gas prices. Despite a study by the California Energy Commission (CEC) showing that the ethanol community is expected to double its current production capacity in four years and a study by Downstream Alternatives, Inc. showing that California has substantial potential ethanol production capacity, Gov. Davis requested a "waiver" from the EPA that would have exempted them from meeting federal oxygenate requirement. The EPA denied the request in June 2001, and Davis responded by extending the MTBE phase-out deadline to December 31 2003.

ChevronTexaco's announcement that it would phase out MTBE in advance of the deadline is a defining moment in California's transition from MTBE to ethanol. Based in San Francisco, ChevronTexaco owns two refineries in California and is the largest oil and natural gas producer in the state. Given the extensive network that it has in California, ChevronTexaco's announcement makes clear that major refiners do have the institutional capacity to make a transition from MTBE to ethanol. "We've made good progress with meeting the many difficult logistical, technical and permitting challenges that must be overcome to remove MTBE statewide," said Dave Reeves, president of North America Products, a refining and marketing division of Chevron U.S.A. Inc. 


\section{LEGISLATIVE UPDATES}

\section{McCain/Lieberman Climate Bill}

On Jan 8, 2003, Senators John McCain (R-AZ) and Joseph Lieberman (D-CT) introduced the "Climate Stewardship Act of 2003." The bill requires the United States Environmental Protection Agency (US EPA) to promulgate regulations that limit the greenhouse gas (GHG) emissions of the electricity generation, transportation, industrial, and commercial economic sectors.

The bill sets forth specific GHG emission reduction requirements for the target years 2010 and 2016, reaching 1990 emission levels by 2016 (5123 million metric tons). Affected companies include any company from the above-mentioned sectors that emit more than 10,000 metric tons of greenhouse gases per year. The quantity of emissions (number of tons) are to be specified by the Administrator of the EPA, and would be based upon the EPA's Inventory of United States Greenhouses Gas Emissions and Sinks. Companies not meeting emissions limits would be fined for each ton of greenhouse gases over the limit at the rate of three times the market value of a ton of greenhouse gas. In order to achieve these target emission levels, the bill provides for the creation of a national GHG "cap and trade" system for all covered entities. Essentially, the cap and trade system would allow companies to buy and sell "permits" to emit greenhouse gases. The program rewards companies that have reduced their emissions through energy efficiency improvements or the use of renewable energy because they would be able to sell emission permits to less energy-efficient companies. Thus, the idea of the system is to create a market-based incentive for energy efficiency: "Our approach promises environmental progress in reducing harmful global warming, economic progress by creating new high-tech jobs to meet emissions goals, and international progress by showing our allies that we're serious about this global problem," said Sen. Joseph Lieberman.
The bill stands in stark contrast to White House policies regarding climate change. President Bush does not support any policy that imposes required target levels to be met by companies. Instead, Bush has relied upon the 'voluntary' GHG reporting program (1605(b)) of the Energy Policy Act of 1992, which allows companies to report their yearly emissions figures should they choose to do so. To this end, the White House is expected to reveal voluntary emission reduction agreements with a variety of industry sectors on Feb 6, 2003. In contrast with the McCain/Lieberman bill that provides the federal government with the authority to monitor and enforce national GHG standards, Bush's voluntary system leaves reporting entirely up to individual companies and does not set concrete long-term reduction levels.

The bill has clear implications for the United States biofuel industry. If passed, the bill would require a reduction in $\mathrm{GHG}$ emissions for the first time on a national scale. Greater use of renewable energy fuels like ethanol and biodiesel could become a significant strategy for reducing GHG emissions in the transportation sector. According to numerous studies, including a recent one by the United States Department of Agriculture, ethanol yields far more energy than is needed for its production (See Recent Studies).

\section{Rep. Kaptur Introduces Biofuels Energy Independence Act}

\author{
Congresswoman Marcy Kaptur (D-OH) \\ reintroduced, as her first bill of the $108^{\text {th }}$ \\ Congress, the Biofuels Energy Independence \\ Act (H.R. 130) to promote U.S. energy \\ independence from foreign suppliers and \\ accelerate the development of ethanol and \\ biodiesel. The bill calls for increased production \\ of biofuels and the creation of a biofuels reserve \\ by directing the United States Department of \\ Agriculture to guarantee loans for entities that \\ develop, produce, and distribute biofuels. \\ "America needs a 'declaration of energy \\ independence.' We must replace imported \\ petroleum with renewable energy that will create \\ thousands of jobs, control pollution, cut
}


greenhouse gas emissions, and restore our freedom," said Rep. Kaptur. She is the Ranking Democratic Member on the House Appropriations Agriculture and Rural Development Subcommittee, and has consistently been a vocal supporter of biofuels.

\section{RECENT STUdIES}

\section{Energy Balance of Corn Ethanol: An Update}

In July 2002, the United States Department of Agriculture released a study concerning the net energy balance of ethanol. The report, authored by Hosein Shapouri and James Duffield of the USDA's Office of the Chief Economist and Michael Wang of Argonne National Laboratory, concludes that the production of ethanol "yields 34 percent more energy than it takes to produce it, including growing the corn, harvesting it, transporting it, and distilling it into ethanol."

The report finds that the increasing efficiency of ethanol production is due in large part to advances in technology that have been adopted by "most ethanol plants in production today." The authors contend that advances in crucial areas such as fertilizer production, fuel conversion, and corn harvesting requires that any study of the net energy value (NEV) of ethanol must rely upon up-to-date information: "It is important that the most current data available be used to estimate the NEV of ethanol because the efficiency of growing corn and converting it to ethanol has improved significantly over the past 20 years." Studies that do not take new technologies into account, the report concludes, are inherently flawed. Specifically, the study addresses the conclusions of a controversial study entitled "The Limits of Biomass Energy" by David Pimentel of Cornell University. In his study, Pimentel states that ethanol has a negative net energy value. The authors conclude that in nearly every part of his study, Pimentel makes use of information based on technology that is clearly outdated. They also emphasize that Pimentel's findings in the areas of corn yield, ethanol conversion, and fertilizer application rates are often derived from outdated statistics, and rarely taps information from modern ethanol production.

\section{Effects of Renewable Fuels Standards}

A second USDA study, released in August 2002, analyzes the anticipated effects of the Renewable Fuels Standard (RFS), as proposed in the Energy Policy Act of 2002 (S.517). The study was requested by Senator Tom Harkin (DIA) to examine how the proposed RFS would affect "commodity markets, farm income, and employment."

As it was laid out in the 2002 Senate passed energy bill, the RFS would have ensured the creation of a 5 billion gallon per year market for renewable fuels over the next 10 years. This would have more than doubled the size of the current ethanol market.

According to the analysis, the effects of this increase would be positive on a variety of levels. Increased ethanol production would be followed by increased demand for corn and sorghum, and by 2011 , "prices would be up about 13 cents per bushel or 5 percent." The increased demand for ethanol would also impact net farm income. In the short-term (2002-05), the effects on farm income would be relatively small, but the period 2006-2011 would see net farm income rise "on average by $\$ 0.7$ billion a year." The USDA study found that the increasing size of the ethanol market would also influence employment, creating an estimated 13,500 jobs in the United States economy. Over half of these new jobs would come from nonfood sectors, while the rest would come from the farming sector and the food processing sector. For more information on these reports, please visit USDA's Office of the Chief Economist at: http://www.usda.gov/oce/ 


\section{ETHANOL NEWS BRIEFS}

\section{New York seeks Oxygenate Waiver}

New York State has asked the United States Environmental Protection Agency (EPA) for an exemption from the federal oxygenate requirement in the area surrounding Manhattan. In their letter, officials express concerns about the economic and logistic feasibility of making a transition to an MTBE-free gasoline blend. New York officials argue that replacing MTBE with ethanol will prove too costly for oil producers who will be forced to import the ethanol from out-of-state producers. They also contend that they can meet clean air standards without any gasoline oxygenate at all. New York now becomes the second state that has requested a gasoline oxygenate exemption. California recently made a similar appeal that was ultimately rejected by the EPA and the Bush administration. According to an official with the New York State Department of Environmental Conservation, California relied too much on the argument that ozone requirements could be met without use of an oxygenate. The official forecasted greater success for New York's appeal because the application details the potential negative effects that ethanol could have on air and water quality.

\section{Ethanol Industry Pushes FFV Hybrid Using CLEAR Act Credits}

Officials from the ethanol industry are considering a new avenue for expanding the use of ethanol in cars by way of a Flexible Fuel Vehicle (FFV) hybrid. Under the Clean Efficient Automobiles Resulting from Advanced Car Technologies Act of 2001 (CLEAR Act), taxpayers receive significant credits for purchasing hybrid vehicles. 'Hybrids' are vehicles that run on gasoline and use an electric motor as a backup source of energy, thereby greatly boosting fuel economy. The ethanol industry is anxious to see vehicle manufacturers come up with a FFV hybrid, a car that would give hybrid owners the chance to use ethanol as opposed to gasoline. Doing so, officials contend, would greatly reduce United States dependence on foreign oil.

\section{Canadian Company Producing Cellulosic Ethanol at Demonstration Plant}

The Canadian company Iogen has announced further progress in the commercial production of cellulosic ethanol at its EcoEthanol ${ }^{\mathrm{TM}}$ demonstration plant. Iogen has announced that it is successfully processing 25 tons of wheat straw per week into fermentable sugar, and is on track to produce 320,000 liters (approximately 85,000 gal) of ethanol annually. The process involves the use of advanced enzyme technology to convert cellulose material such as straw into fermentable sugar, the essential component in ethanol production. "This step toward commercialization is great news for Canada and Kyoto... EcoEthanol will create jobs, put money in farmers' pockets, and benefit the environment. EcoEthanol and Iogen are proof of the new economic opportunities associated with Kyoto implementation," says Iogen Executive Vice President Jeff Passmore. As opposed to starch-based ethanol, made primarily from corn in the United States, cellulosic ethanol is derived from a variety of fuel stocks such as crop residues, forestry wastes, and organic municipal waste.

\section{USDA/DOE Awards Biofuel Grants}

The Value-Added Agricultural Product Market Development grant program (http://www.rurdev.usda.gov/rbs/coops/vadg.htm) was originally created by the Agriculture Risk Protection Act of 2000 to help farmers develop and market innovative new uses for their crops. Several biofuels projects received funding in FY02, including: 
- \$167,500: Dakota Renewable Fuels, LLC, Fargo, ND, to develop a 30-million gallon dry mill ethanol plant.

- \$450,000: Treasure Valley Renewable Resources, Weiser, ID, to develop a 15-million gallon ethanol fuel production facility.

- \$211,650: Green Virginia Ethanol Project, Reedville, VA, to conduct a feasibility study on fuel ethanol production in a grain mill or cellulose hydrolysis or hybrid facility.

- \$150,000: American Corn Growers Association, Washington, DC, in order to provide farmers and farm organizations with the tools to evaluate the feasibility of ethanol production and build consumer awareness of the role ethanol-blended fuels could play in meeting Clean Air Standards.

\section{Minnesota Focuses On Cuts In State Ethanol Program}

In lieu of the state's growing budget deficit, Minnesota Governor Tim Pawlenty $(\mathrm{R})$ recently called for the elimination of Minnesota's ethanol payment program that provides nearly \$27 million annually to Minnesota's 13 ethanol plants. The ethanol community expressed deep concern about the impact the cuts could have, "This is drastic and could have severe consequences for a number of the ethanol producers in the state," said Bill Lee, general manager of Chippewa Valley Ethanol Co. in Benson, Minnesota.

Although state legislators decided not to eliminate the program, the state Senate voted to trim the program by $\$ 3$ million and the state House voted to cut roughly $\$ 5$ million. When the Senate and House reach a consensus on their budget proposals, they must forward the budget to Governor Pawlenty for approval.

\section{Ethanol Production Being Explored in New Jersey, Texas, and Michigan}

The year 2002 has been a remarkably good one for the ethanol industry. In addition to consistently breaking production records, 12 new ethanol plants have begun production across the country. Some states that have never hosted ethanol plants are exploring the prospect of producing ethanol in-state.

In the Northeast, New Jersey Governor, James E. McGreevey, announced his support for the building of New Jersey's first ethanol plant. The plant is a project of Garden State Ethanol, a private corporation of farmers and investors who hope to build, own, and operate the first facility. The plant would use an anticipated four million bushels of locally grown corn each year to produce up to 40 million gallons of ethanol annually.

In June 2002, farmers of the Brazos Valley in Central Texas formed the Central Texas Ag Development (CTAD), a group charged with bringing an ethanol plant to the valley. CTAD has recently received a $\$ 65,000$ matching grant from the United States Department of Agriculture in order to produce a feasibility study. "We believe strongly that ethanol production can provide a much needed market for Texas grain while helping to improve our country's security," said Kit Worley, a San Gabriel farmer and new chairman of the CTAD board.

Michigan Ethanol will soon be the first ethanol plant to be built in the state. The Michigan Corn Processor's Development Committee has teamed up with Broin Co., a South Dakota-based company specializing in ethanol plant creation. "The people I talk to are happy about the opportunities...We've been waiting for this for years," said Phil Block, a dairy farmer from Birch Run, Michigan. The plant is scheduled to run 24 hours a day, seven days a week, create 41 jobs, contribute an estimated $\$ 60$ million per year to the area's economy, and produce 40 million gallons of ethanol per year. 


\section{Brazil Looks to Expand Ethanol Production}

Sparked by the energy crises of the 1970's, Brazil's sugar cane-based "Pro-Alcohol Program" launched Brazil into the world ethanol market. Despite rough times for the industry in the late 80's and early 90's, Brazil is once again looking to expand its domestic production. Brazil's Vehicle Manufacturer Association has stated that technological progress in fuel injectors and "flex fuel" systems, which automatically adjusts to any mixture of gasoline and ethanol, has made the rebirth of the alco-car possible. The alco-car is a car running on cane-based 96-proof hydrous ethanol, or alcohol. The expansion has also drawn praise from public sector figures that see the value in a diversified fuel market: "Why buy a car that runs on just alcohol or just gasoline. It is imperative, if we are to revive our alcohol industry, to give consumers a choice at the pump," said Joao Carlos, Agriculture Secretary of Sao Paulo state, Meirelles.

\section{UPCOMING EVENTS}

Third Annual Harvesting Clean Energy Conference

Monday, Feb 10 - Tuesday, Feb 11, 2003

Boise, Idaho

Contact: Diane Gasaway

360.943-4241

dgasaway@wreca.coop

http://www.harvestcleanenergy.org/conference/ for more information

Renewable Fuels Association's National Ethanol Conference: Policy \& Marketing

Feb. 17-19, 2003

Scottsdale, Arizona, http://www.ethanolrfa.org/nec.shtml for more information

\section{NOTABLE QUOTABLES}

"It is time to pay attention to where the oil comes from, and it is time to do something here at home to revive the sagging and critical state of rural America and, at the same time, create jobs from coast to coast... acres can be turned to productive use and move farmers from farming for a government check by going to their mailbox, to farming the marketplace and producing new, renewable clean fuels for America."

Rep. Marcy Kaptur (D-OH), introducing the Biofuels Energy Independence Act of 2003 (H.R. 130), January 8, 2003.

\section{Writer: Josh Alban \\ Editors: Carol Werner, Jeremy Ames}

Please distribute ECO to your colleagues, or send us their email addresses and we will add them to our distribution list. Article and commentary submissions are encouraged, and should be sent via email.

$$
\begin{gathered}
\text { Environmental and Energy Study Institute } \\
\text { 122 C St. NW, Suite 630 } \\
\text { Washington DC, 20001 } \\
\text { (202)662-1885, Fax: (202) 628-1825 } \\
\text { eco@eesi.org }
\end{gathered}
$$

Please visit us at http://www.eesi.org/

We welcome your suggestions, comments, and questions. 


\section{$\mathrm{E}_{\mathrm{THANOL}}$}

\section{Climate Protection \\ Oil Reduction}

\author{
A PUBLIC FORUM \\ VOL. 2, ISSUE I \\ JULY 2002
}

WELCOME TO “ECO." THIS NEWSLETTER IS WRITTEN TO PROVIDE THE MOST CURRENT INFORMATION ABOUT ETHANOL AND SERVE AS A PUBLIC FORUM. THE ENVIRONMENTAL AND ENERGY STUDY INSTITUTE (EESI) HOPES TO BUILD CONSENSUS WITHIN THE ENVIRONMENTAL COMMUNITY REGARDING THE POTENTIAL BENEFITS OF ETHANOL - AND PARTICULARLY THE EXPANDED OPPORTUNITIES PROVIDED BY CELLULOSIC ETHANOL - WITH A SPECIAL FOCUS ON CLIMATE PROTECTION. ETHANOL CAN ALSO BE A POLITICAL BRIDGE TO BROADER ALLIANCES IN SUPPORT OF CLIMATE INITIATIVES.

MANY IN THE ENVIRONMENTAL COMMUNITY HAVE MADE STRONG STATEMENTS IN SUPPORT OF ETHANOL AS A LOW-CARBON FUEL WITH LARGE POTENTIAL BENEFITS TO REDUCE LIFE-CYCLE GREENHOUSE GAS (GHG) EMISSIONS. ETHANOL ALSO REDUCES CARBON MONOXIDE EMISSIONS AND OUR RELIANCE ON OIL, CONTAINS NO SULFUR AND HELPS TO ELIMINATE SMOG THROUGH ITS USE AS AN OXYGENATE FOR GASOLINE. CELLULOSIC ETHANOL, WHICH IS PRODUCED FROM AGRICULTURAL OR WOOD WASTES, PROVIDES EVEN GREATER GHG EMISSION REDUCTIONS THAN CORNBASED ETHANOL, PROMOTES RURAL ECONOMIC REVITALIZATION AND OFFERS A SOLUTION TO WASTE DISPOSAL PROBLEMS. HOWEVER, THERE HAVE BEEN CONCERNS ABOUT ETHANOL RANGING FROM VOLATILE ORGANIC COMPOUNDS (VOCS) TO CORPORATE WELFARE. ECO ADDRESSES THESE AND OTHER ISSUES. PLEASE SHARE YOUR VIEWS WITH US AND WE WILL ADDRESS THEM IN “ECO.”

\section{IN THIS ISSUE:}

Commentary: Replacing MTBE: Oil Or Ethanol? By Brooke Coleman, Renewable Energy Action Project ...Page 2

RENEWABLE FUELS STANDARD PASSES

SENATE ...PAGE 4

\section{CALIFORnia's Governor POSTPONES STATE} MTBE BAN ... PAGE 5

\section{LEGISLATIVE UPDATES}

2002 Farm Bill Contains New Incentives For

Biofuel Production ...Page 6

Senators Introduce Bill To Address Highway Trust Fund Shortfall From Ethanol ...Page 6

\section{Recent Studies}

DOE Finds No Infrastructure Barriers To Increasing The Ethanol Market ...Page 7

Michigan State Univ. Researchers Find Ethanol Has Net Energy Benefit ...Page 7

Ethanol News Briefs ...Page 8

Upcoming Events ...Page 8

Notable Quotables ...Page 9 


\title{
Replacing MTBE: Oil or Ethanol?
}

\section{COMMENTARY}

\section{By Brooke Coleman, Renewable Energy Action Project}

As the Energy Bill Conference Committee considers how to address widespread MTBE contamination in the upcoming weeks, much of the debate will center on the renewable fuels standard (RFS). The package of provisions that bans MTBE in the Senate energy bill also contains the so-called ethanol mandate. Vociferous attacks were launched against the RFS in the Senate Energy Bill debate. The Renewable Energy Action Project's rebuttals to these criticisms are printed below.

\begin{abstract}
"Forcing states to use ethanol amounts to a transfer of wealth from coastal states to the Midwest ..." An ethanol requirement offers every state the opportunity to develop a homegrown biofuels industry, similar to those developed in the Midwest. Ethanol is a U.S. product. Petroleum compounds, like those offered by the oil industry to replace MTBE, originate largely outside the United States. Perpetuating petroleum use amounts to a transfer of wealth from all states to other countries and a handful of multinational oil companies.
\end{abstract}

"States like California need more time to comply ..."

Three out of four major California gasoline refiners have committed to phasing out MTBE by the end of 2002, replacing the additive with ethanol. Those three refiners alone have made shipping and infrastructure arrangements to blend at least 400 million gallons of ethanol in California in 2003.

"The RFS fleeces American consumers ..."

Every gallon of liquid fuel consumed in the United States, whether oil or ethanol, is subsidized. While ethanol receives less than $\$ 1$ billion in annual subsidies, oil is supported by a minimum of $\$ 15$ billion annually, not including the cost of overseas military deployment. In a market where only two products are available to meet demand, a vote against ethanol is a vote for oil. Americans are better off with ethanol.

“Ethanol poses overall transportation and infrastructure problems ..."

A January 2002 report completed for the U.S. Department of Energy concluded, "no major infrastructure barriers exist" for expanding the U.S. ethanol industry to 5 billion gallons.

"There is dangerously high market concentration in the ethanol industry ..." Roughly six multinational oil companies dominate 99 percent of the transportation fuels industry. The RFS reserves an extremely small percentage of this market (roughly 1-3 percent) for renewable fuels. It compels dozens of existing and future ethanol producers to compete within this market share. Because two production facilities produced nearly every gallon of MTBE, the RFS improves market diversification and price stability, and on balance, significantly increases competition in the overall fuels market.

"Increasing ethanol use depletes the Highway Trust Fund ..."

Efforts are underway to ensure that the Highway Trust Fund is not depleted by increased ethanol use. On balance, ethanol costs the federal government a fraction of the price of using oil in terms of federal subsidies (See Legislative Updates) 
"Ethanol has mixed environmental results ..."

Ethanol dilutes toxics, reduces sulfur content, and minimizes the need for highly carcinogenic octane boosters such as aromatics, benzene, toluene and xylene. It increases combustion efficiency in the dirtiest vehicles, which produce more than half of all vehicular emissions. And according to recent vehicle tests in California, ethanol also reduces emissions in latest technology vehicles in comparison to nonoxygenated fuels. ${ }^{1}$

"The 'safe harbor' measure warrants a vote against the provision ..."

The American Petroleum Institute (API), not the ethanol industry, insisted on liability protection. Lawmakers should stand up to API and strike this provision in conference.

"An ethanol mandate will strain fuel supplies ..."

Just the opposite is true. When MTBE is eliminated, there will be a volume and octane void (roughly 4 percent of the national gasoline pool) that must be filled. Without the RFS, the oil industry will try to replace MTBE using petroleum-based products to avoid losing market share. If the oil industry falls short, higher pump prices will be blamed on the MTBE phaseout. An RFS, on the other hand, requires the oil industry to utilize renewable fuels as a partial fix, in effect spreading out the burden of replacing MTBE on many more producers and industries. It compels greater competition and price stabilization among those that are responsible for replacing MTBE.

"Ethanol is Not a Renewable Fuel ..."

Credible and independent studies from the Department of Energy's Argonne National Laboratory, the U.S. Department of Agriculture, and Michigan State University confirm that ethanol is a renewable resource with a net energy benefit in comparison to gasoline ranging from 27-58 percent. The Cornell University study that challenges the renewable nature of ethanol assigns no energy value to ethanol coproducts and uses outdated data to estimate the energy costs of inputs such as fertilizers and irrigation.

“The greenhouse gas benefits of blending ethanol are minimal ...”

According to the Argonne National Laboratory, for every gallon of petroleum replaced by corn ethanol, greenhouse gas emissions are reduced by 35 percent. For every gallon of gasoline replaced by biomass ethanol, the greenhouse gas reduction potential is greater than 100 percent with the co-production of electricity.

"The ethanol mandate benefits corporate producers, not farmers ..."

Nine out of ten new ethanol facilities are farmer-owned cooperatives. While the ethanol mandate benefits both corporate and small producers, states are free to meet their respective ethanol requirements using whichever strategy they prefer, including providing extra incentives for small producers and biomass ethanol production. Opposition to the RFS benefits primarily the six multi-national oil giants that dominate the liquid fuels industry.

As always, EESI welcomes your comments about the issues raised in this commentary and throughout ECO. Responses, article and commentary submissions, and feedback can be sent to eco@eesi.org

\footnotetext{
${ }^{1}$ http://www.arb.ca.gov/cbg/meeting/2001/071201AAPrstn.pdf
} 


\section{Renewable Fuels Standard Passes Senate Negotiations Begin with House}

On April 25, the Senate passed the Energy Policy Act of 2002 (S. 517) by a vote of 88-11. Included in the comprehensive energy package was an agreement to ban the fuel additive MTBE, repeal the federal oxygenate requirement for reformulated gasoline, and establish a national Renewable Fuels Standard (RFS) for motor vehicle fuels. The agreement was the result of months of negotiations between the biofuels industry, state air quality officials, and the American Petroleum Institute convened, by Senate Majority Leader Tom Daschle (D$\mathrm{SD}$ ), sponsor of the original RFS proposal, along with Senator Jeff Bingaman (D-AZ), chairman of the Energy and Natural Resources Committee (see ECO XVI).

The Renewable Fuels Standard would require the use of 5 billion gallons of renewable fuel by 2012, and an equivalent percentage of total market-share thereafter. Qualifying fuels include ethanol and biodiesel. The proposal also would allow each gallon of ethanol derived from cellulosic biomass to be counted as 1.5 gallons of renewable fuel.

The fuel additive MTBE would be banned within four years of enactment and governors would be given the discretion to waive the oxygenate requirement for reformulated gasoline, ending years of controversy and debate on the elimination of MTBE which has been found to contaminate groundwater. The 1990 Clean Air Act amendments require regions not in compliance with federal air quality standards to sell reformulated gasoline blended with an oxygenate. MTBE has been the oxygenate of choice in the largest RFG markets of California and the Northeast.

Despite winning the support of a bipartisan coalition of Senators, including Senator Frank Murkowski (R-AK) the influential rankingmember on the Senate Energy and Natural Resources Committee, the debate on the RFS proved to be very heated. The RFS was the last major issue debated when S. 517 was brought to the floor of the Senate in April. Opposition to the provision was led by Senators Dianne Feinstein (D-CA) and Charles Schumer (D-NY), who argued that the RFS would benefit only Midwestern farmers at the expense of consumers in their states, which lack established biofuels industries. They also challenged the environmental benefits of ethanol. "I want to make clear my strong opposition to this greedy and misguided renewable fuels requirement," said Feinstein in the course of the debate, "The mandate is a dangerous step that could force gasoline prices to soar, cause shortages of fuel, create more smog, and usher in the next energy crisis."

Supporters countered these arguments and ultimately won the debate, defeating an amendment to strike the RFS from the bill by a vote of $69-30$ and all subsequent amendments to weaken the provision. "The RFS is probably the most significant oil-dependency related provision in the energy bill," said Senator Ben Nelson (D-NE), former Chair of the Governor's Ethanol Coalition. "In addition to establishing a standard for ethanol use, it is sure to boost the agriculture economy while reducing the environmental impact of fuel emissions. With the RFS, everybody wins. Agriculture, consumers, the environment, and the oil producers will benefit."

The debate will now continue in the HouseSenate conference committee. The House energy package, Securing America's Future Energy Act of 2001 (H.R. 4), passed last fall does not contain a Renewable Fuels Standard. However, Conference Committee chairman Rep. Billy Tauzin (R-LA) has publicly stated he expects some compromise on the RFS to emerge from the committee. The RFS has also been endorsed by the Bush Administration. However, Air Quality Subcommittee Chairman Joe Barton (R-Texas) has signaled he may lead an effort to oppose the RFS in conference, and he'll likely be joined by House Transportation Committee chairman Don Young (R-AK), who opposes the RFS because of the effect the sale of ethanol has 
on the Highway Trust Fund (see Legislative Updates). The committee has announced it will deal with the least controversial provisions of the bills first, saving provisions such as the RFS, drilling in the Alaska Arctic National Wildlife Refuge, and fuel efficiency standards for last.

\section{Other Biofuels Related Provisions in the Senate Energy Bill}

In addition to the RFS, S. 517 also contains a provision requiring Federal fleets to use at least 10 percent ethanol and 2 percent biodiesel within give years, increasing to 20 percent biodiesel in ten years, where such fuels are reasonably available. The Small Producer Ethanol Credit is also modified. The definition of small producer is increased from less than 15 million gallons of capacity, to less than 60 million gallons, and farmer-owned cooperatives are made eligible to use the credit. No similar provisions are included in H.R. 4.

\section{CALIFORNIA'S GOVERNOR POSTPONES STATE MTBE BAN MAJOR OIL COMPANIES ON SCHEDULE to Meet Original Deadline}

California Governor Gray Davis ended months of speculation in March by announcing his decision to postpone the state's ethanol ban by 12 months from the original December 31, 2002 deadline. "If I could snap my fingers and make MTBE go away tomorrow, I would. But we've seen this movie before and I am not going to allow Californians to be held hostage by another out-of-state energy cartel," said Davis comparing the ethanol industry to electric utilities he blamed for the 2001 energy shortages.

Last summer, the Bush Administration officially denied California's request for a waiver from federal oxygenate standards. The Clean Air Act requires regions not in compliance with federal air quality standards to sell reformulated gasoline blended with either ethanol or MTBE (see ECO XV). California officials had argued that switching to ethanol would be cost prohibitive, since very little is produced in the state, and would need to be transported from the Midwest, at least initially. They had also argued that insufficient ethanol capacity existed to meet California's needs, despite an August report by the California Energy Commission (CEC) that concluded the ethanol industry would double its capacity within four years

After the waiver was denied and subsequent court challenges failed, Davis sought a remedy in the energy legislation being debated in the U.S. Senate, "but there's a chance that it might not become law and so it is my duty to take action to protect Californians from paying $\$ 3$ per gallon at the pump," Davis explained (see RFS Story).

Despite the postponement, several major gasoline suppliers in the state have announced plans to switch over to ethanol by the original deadline. British Petroleum, the state's largest gasoline supplier, was the first to announce it would meet the original deadline, and was followed soon after by Shell Oil and Phillips Petroleum; ExxonMobil recently announced it would make the switch by "early 2003." Together, the companies account for more than 60 percent of gasoline sales in the state. Shell spokesman Cameron Smyth noted that the company had been making preparations to meet the original deadline, and "we feel certain that not only the infrastructure is there but the supply will be there as well."

San Francisco-based ChevronTexaco opposed the postponement of the MTBE ban, but has not yet announced if it plans to meet the original deadline. Several suppliers had expressed concern that Kinder Morgan Energy Partners, which owns a major pipeline and other infrastructure necessary to transport the gasoline, would not be able to meet the 2002 deadline. In response, the company issued a statement making it clear they were already prepared to transport ethanol-blended fuel if their customers were ready. 


\section{LEGISLATIVE UPDATES}

\section{Farm Bill Contains New Incentives for Biofuel Production}

The Farm Security and Rural Investment Act of 2002 (H.R. 2646), signed by the President on May 13th, is the first Farm Bill to contain an energy title. The title, which originated in the Senate with strong bipartisan support, establishes several new programs designed to promote agriculture-based renewable energy development. In total, the energy title provides $\$ 405$ million over five years:

- Commodity Credit Corporation Bioenergy Program - continues the existing program, which reimburses ethanol and biodiesel producers for the purchase of commodities used to expand existing production (\$204 million)

- Federal Procurement of Biobased Products - creates a program to label and certify biobased products, and to encourage federal agencies to purchase them ( $\$ 6$ million, program does not apply to biofuels)

- Biodiesel Fuel Education Program - establishes a new grant program to educate the public about the benefits of biodiesel ( $\$ 5$ million)

- Renewable Energy System \& Energy Efficiency Improvements - establishes a program to provide loans and grants to assist farmers in purchasing renewable energy systems and making energy efficiency improvements (\$115)

- Biomass Research and Development Act of 2000 - Reauthorizes and extends a multi-agency research initiative to develop electricity, fuels, and chemicals from biomass ( $\$ 75$ million)

In addition, the Biorefinery Grant Program was established to support the creation of facilities that can convert biomass into electricity, fuels, and biobased products, and the Energy Audit/Renewable Resource Assessment Program was created to aid farmers in funding feasibility studies for renewable energy projects. Both programs were authorized at "such sums as necessary" and are subject to annual appropriations. Also in the Farm Bill, the Conservation Reserve Program (CRP) within the Conservation Title was amended to allow biomass harvesting for energy production on CRP lands.

Despite the intense partisan debate that the Farm Bill generated, the energy title was relatively noncontroversial. "I truly believe we can produce just about anything from corn, soybeans, and other agricultural products that we can produce from oil. The energy title will bring us a significant step closer to that end," said Senator Harkin (D-IA), chairman of the Senate Agriculture committee and chief author of the title.

\section{Senators Introduce Bill to Address Highway Trust Fund Shortfall from Ethanol} On June 25, Senator Max Baucus (D-MT), chairman of the Senate Finance Committee, along with Senators Tom Harkin (D-IA), Kit Bond (R-MO), and Mike Crapo (R-ID) introduced the MEGA Trust Act - Maximum Growth for America through the Highway Trust Fund (S. 2678). "This bill will boost our highway system funding, create more good-paying jobs in Montana and across the country, and ensure that we have safe highways and can move our goods and services," said Baucus. The legislation is designed to update the Highway Trust Fund mechanism, which funds state highway and public transit projects and is funded through a federal tax on motor vehicle fuels.

Among its various provisions, the legislation addresses concerns raised by Highway Trust Fund advocates that ethanol blended fuels reduce revenue to the fund. Under current law, tax revenue from ethanol is treated differently from gasoline, as much of the revenue from ethanol goes to the US Treasury's General Fund, as opposed to the Highway Trust Fund. S. 2678 would amend the program to ensure that revenue from ethanol-blended fuels is treated the same as gasoline revenues. In addition, because ethanol is given 
a partial exemption to the federal fuels tax, a gallon of E10 (10 percent ethanol, 90 percent gasoline) generates 5.3 cents less revenue per gallon than a gallon of gasoline, resulting in less revenue for the Trust Fund. S. 2678 would make up the revenue shortfall to the Highway Trust Fund with general revenue funds.

"We appreciate Senator Baucus' initiative to put these options on the table to increase funding to the Highway Trust Fund," said John Horsley, Executive Director, American Association of State Highway and Transportation Officials, whose board of directors had previously recommended to Congress that the ethanol shortfall be addressed to increase revenue to the trust fund.

\section{RECENT STUDIES}

\section{DOE Finds No Infrastructure Barriers to Increasing the Ethanol Market}

In January, the U.S. Department of Energy released a report entitled, "Infrastructure Requirements for an Expanded Fuel Ethanol Industry. "The report examined the current infrastructure of the United States and the variety of changes that would be needed to meet an anticipated increase in the use of ethanol. The report concludes, "No major infrastructure barriers exist..." and that production of the necessary transportation equipment should easily outpace ethanol shipments.

The study calculated the costs of increasing ethanol production to 5.1 billion gallons per year (bg/y) and to $10.0 \mathrm{bg} / \mathrm{y}$. The first scenario was chosen because it is similar to the proposed Renewable Fuel Standard before Congress, the second was chosen to determine if efficiencies of scale would materialize at a higher volume. Comparing the two scenarios, the authors concluded that several infrastructure changes would be needed to achieve either goal, such as construction of new and conversion of old oil tanks to store the ethanol, creation of new rail spurs to handle the new ethanol rail tank cars, and the construction of new distribution locations. The estimated total cost of this capital investment for terminal improvements and retail conversion would be between $\$ 150$ million for the first scenario and $\$ 200$ million for the second. Assessing the other infrastructure needs for a growth in ethanol use, the DOE estimated the costs of ethanol transportation changes to be approximately half a billion dollars.

\section{Michigan State Univ. Researchers Find Ethanol Has Net Energy Benefit} In May, the International Journal of Life Cycle Assessment published "Allocation Procedure in Ethanol Production System from Corn Grain" by Seungdo Kim and Bruce E. Dale of the Engineering Department at Michigan State University. The intent of the study was to determine the net energy associated with the production of ethanol from corn. The authors concluded that ethanol "would significantly reduce domestic use of petroleum even in the worst case scenario."

The authors assigned energy values to all inputs required for ethanol production, as well as all outputs associated with either wet milling or dry milling processes, such as distillers dry grains, corn oil, corn gluten feed, etc. Kim and Dale built upon an earlier study by the Department of Agriculture by updating energy values and assigning a new value to corn oil, equivalent to the soybean oil it would displace on the market. Based on their calculations, the authors found that a 56 percent net energy gain is achieved for corn ethanol, including its transportation to consumers. Therefore, "available energy from ethanol is much higher than the input energy for producing ethanol," regardless of the technology used to produce the fuel 


\title{
ETHANOL NEWS BRIEFS
}

\section{EPA Investigates Emissions from Ethanol Facilities}

The U.S. Environmental Protection Agency is investigating the emissions from several ethanol production facilities. Using new testing methods, EPA has found five facilities in Minnesota and Indiana that are producing higher levels of volatile organic compounds (VOCs) than previously reported. EPA Region 5 Administrator Tom Skinner said these "additional emissions that weren't anticipated" from previous testing could indicate an industry-wide problem and has met with ethanol industry officials to share EPA's preliminary findings and discuss possible solutions. "We have not at this point mandated that any technology be installed," Skinner said. "We want to work individually with these plants because they're not all the same."

\begin{abstract}
ADM Announces Merger with Minnesota Corn Processors
The nation's largest ethanol producer, Archer Daniels Midland Co., has signed a merger agreement with Minnesota Corn Processors, LLC, the nation's second largest ethanol producer. The agreement must still be approved by MCP's 5,000 shareholders, as well as the antitrust division at the Justice Department. ADM currently has an ethanol production capacity of 950 million gallons per year, with MCP a distant second at 140 million gallons per year. The merger is projected to maintain ADM's market-share of the ethanol industry at about 40 percent, but not significantly increase is share due the construction of new facilities not owned by ADM, according the Renewable Fuels Association.
\end{abstract}

\section{New Minnesota Law to Promote Biodiesel}

Under a new law passed by the Minnesota state legislature, and allowed to become law but not signed by Governor Jessie Ventura (I), Minnesota has become the first state in the nation to require the use of biodiesel. The law requires that all diesel fuel sold within the state to contain at least 2 percent biodiesel. The law will take effect when Minnesota's annual production capacity of biodiesel reaches 8 million gallons, or June 30, 2005 whichever is sooner.

\section{Biodiesel Looked Favorably Upon by Canadian Legislators}

The Caucus Working Group on Environmental Technologies, a group of Members of the Canadian Parliament, released a report on renewable energy in March. The report, endorsed by 33 members, recommends immediate action on renewable fuels, including elimination of the excise tax placed on biodiesel and establishment of a Renewable Fuels Standard, similar to the proposals in the US and European Union. The US proposal sets the target of 5 billion gallons of biofuels by 2012; the EU proposal would require a 5.75 percent market-share for biofuels by 2010 . 


\section{UPCOMING EVENTS}

Environmental Qualities of Biofuels

EESI Congressional Briefing

Wednesday, July 31, 2002, 1:00-2:30 p.m.

2168 (Gold Room) Rayburn House Office Building

Washington, DC

Contact: Jeremy Ames, james@eesi.org

Bioenergy 2002 Conference: Bioenergy for the Environment

September 22-26, 2002

Boise, ID

http://www.uidaho.edu/bioenergy/frames.htm for more information

Renewable Energy From Organics Recycling Conference

November 18-20, 2002

Madison, WI

Contact (610) 967-4135 or biocycle@jgpress.com

\section{NotABLE QUOTABLES}

"I said, when I was running for president, that I supported ethanol - and I meant it. I support it now, because not only do I know it's important for the ag sector of our economy, it's an important part of making sure we become less reliant on foreign sources of energy.

... It's good public policy for America. It's good for our air, its good for our economy and its good for our national security."

President George W. Bush, speech at Dakota Ethanol, Wentworth, South Dakota, April 24, 2002.

\section{Writer, Co-Editor: Jeremy Ames \\ Co-Editor: Carol Werner \\ Contributing Writers: Chris Gaston, Noah Chesnin}

Please distribute ECO to your colleagues, or send us their email addresses and we will add them to our distribution list. Article and commentary submissions are encouraged, and should be sent via email.

$$
\begin{gathered}
\text { Environmental and Energy Study Institute } \\
\text { 122 C St. NW, Suite } 700 \\
\text { Washington DC, 20001 } \\
\text { (202)662-1892, Fax: (202) 628-1825 } \\
\text { eco@eesi.org }
\end{gathered}
$$

Please visit us at http://www.eesi.org/

We welcome your suggestions, comments, and questions. 


\section{Appendix II \\ Speaker materials for briefing I - "Environmental Qualities of Biofuels"}




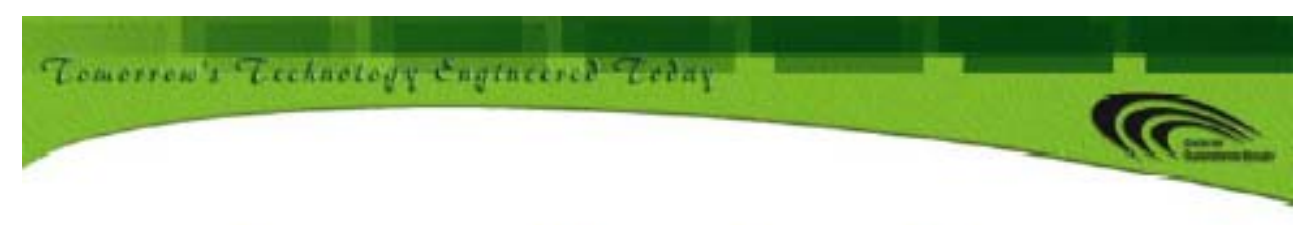

\title{
Energy and Greenhouse Gas Emissions Effects of Fuel Ethanol
}

\author{
Michael Wang
}

Center for Transportation Research

Argonne National Laboratory

Presentation at the Congressional Briefing

Organized By the Environmental and Energy Study Institute

Washington, D.C., July 31, 2002
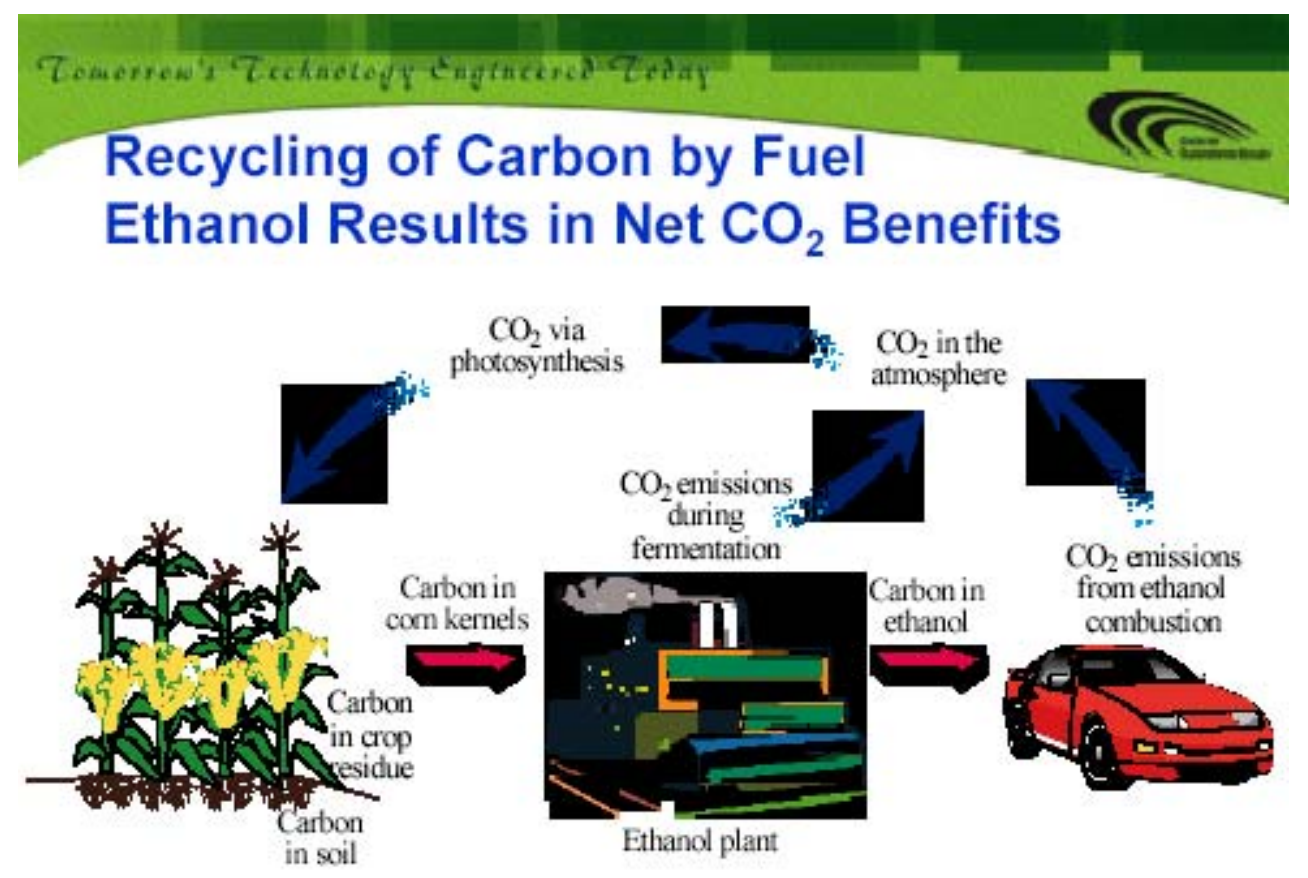

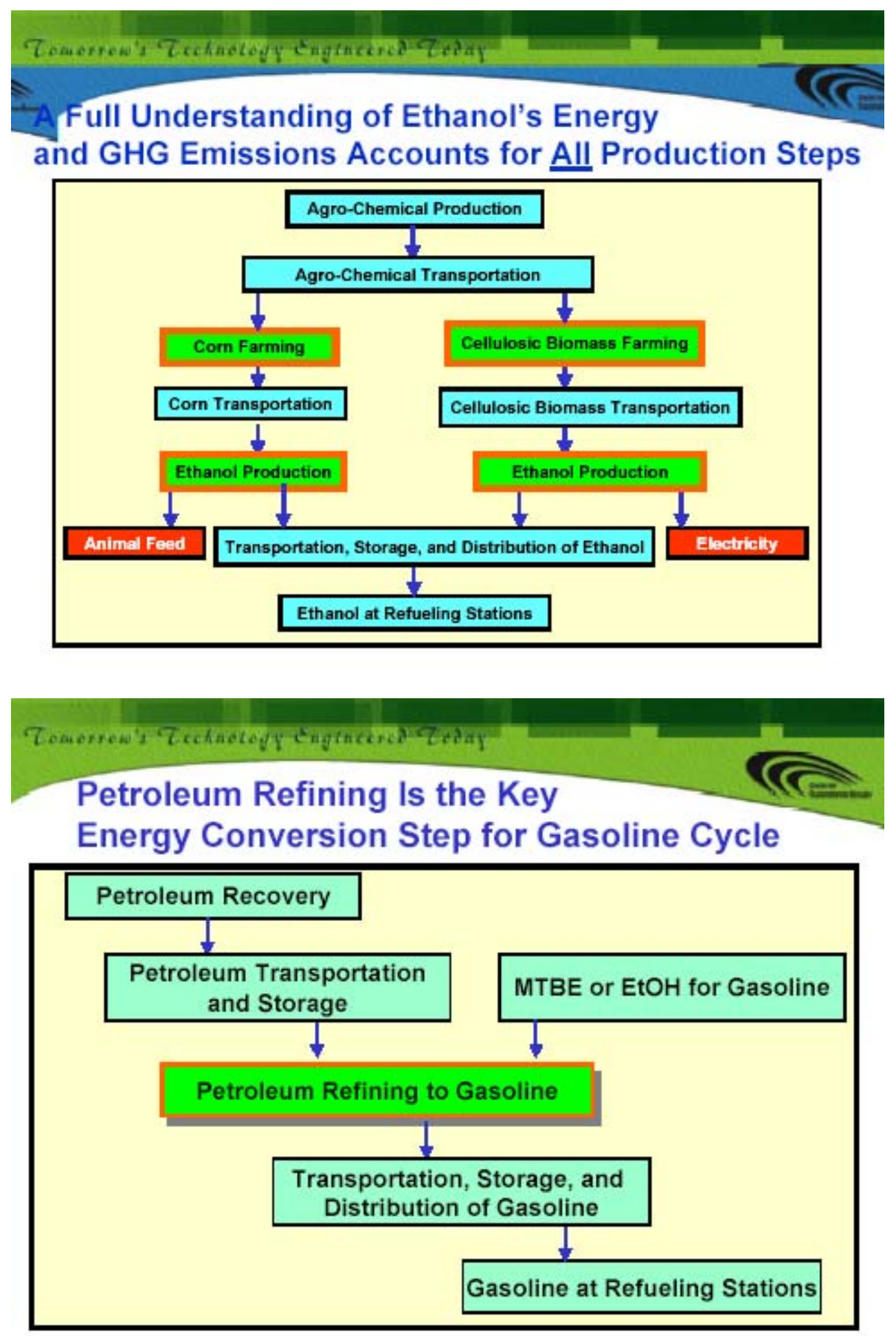


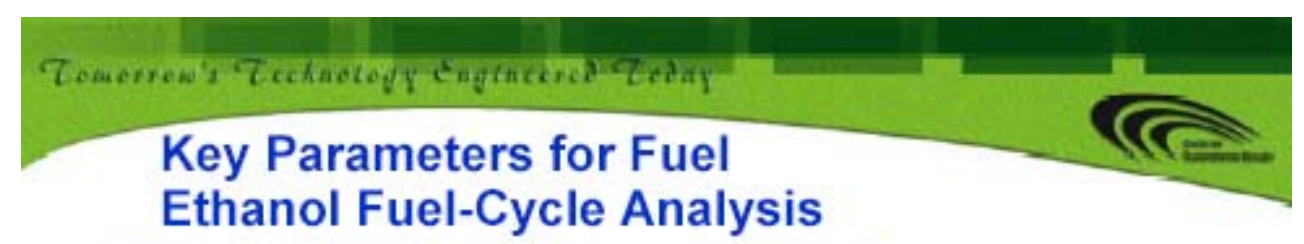

- Chemicals Production

- Energy use for producing:

- Fertilizers $\left(\mathrm{N}, \mathrm{P}_{2} \mathrm{O}_{5}, \mathrm{~K}_{2} \mathrm{O}\right)$

- Herbicides

- Insecticides

- Farming

- Yield per acre: corn and biomass

- Chemicals use intensity

- Soil $\mathrm{N}_{2} \mathrm{O}$ emissions

- Energy use intensity

- Soil $\mathrm{CO}_{2}$ emissions
- Ethanol Production

- Corn ethanol: wet vs. dry milling

- Ethanol yield per unit of feed

- Energy use intensity

- Co-products

- Vehicle Fuel Economy

- Gasoline vehicles for E10

- Flexible-fuel vehicles for E85

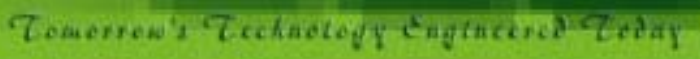

\section{U.S. Corn Output Per Pound of} Fertilizer Used Has Risen (3-yr Moving Average)

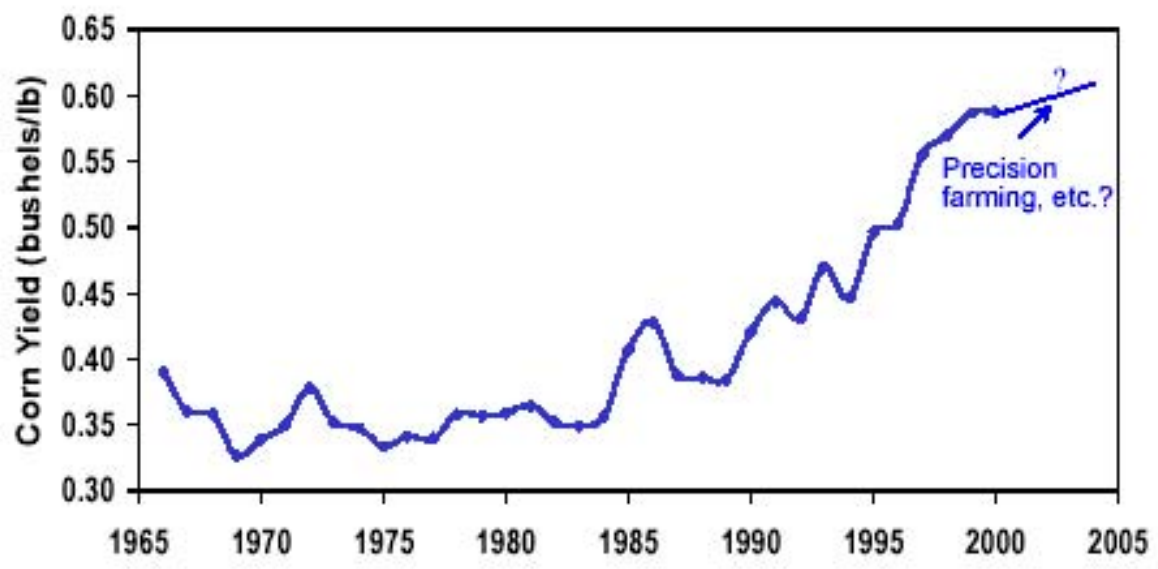




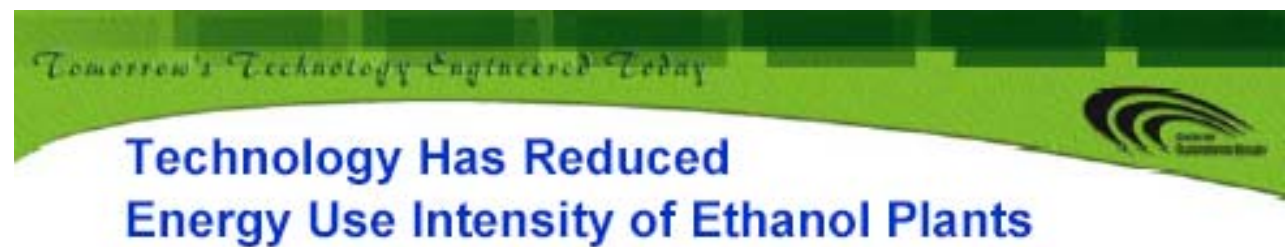

\section{Energy Use Intensity of Ethanol Plants}

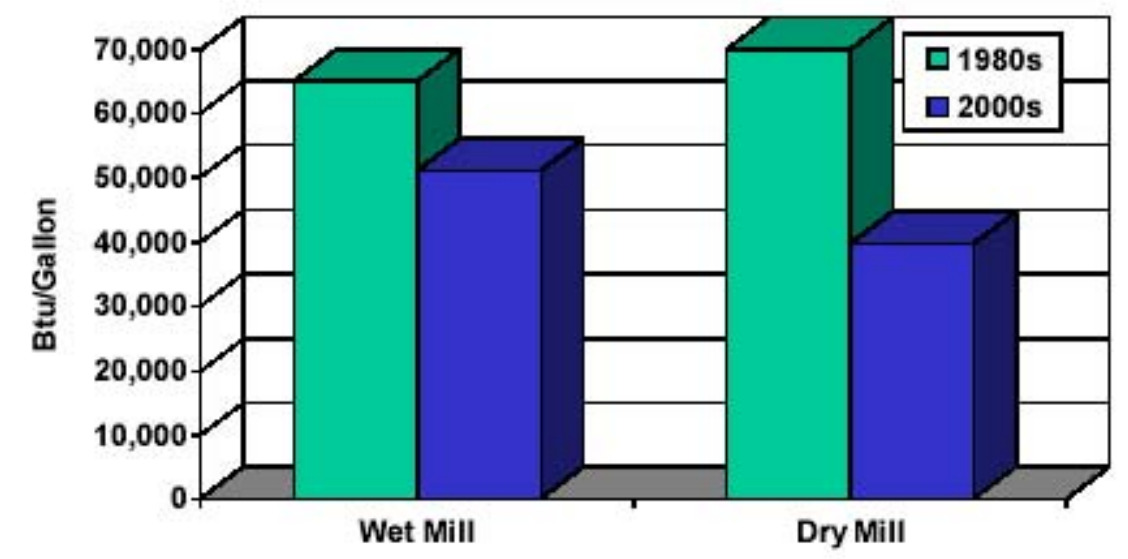

Source: from Argonne's discussions with ethanol plant designers and recent USDA data

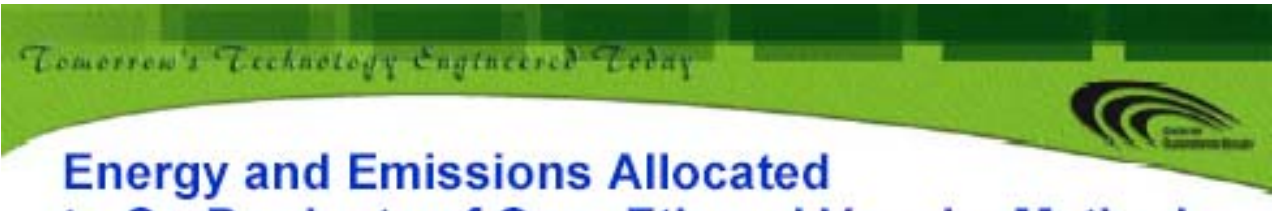
to Co-Products of Corn Ethanol Vary by Method

\begin{tabular}{|l|c|c|}
\hline Allocation Method & Wet Milling & Dry Milling \\
\hline Weight & $52 \%$ & $51 \%$ \\
\hline Energy & $43 \%$ & $39 \%$ \\
\hline Process energy & $31 \%$ & $34 \%$ \\
\hline Market value & $30 \%$ & $24 \%$ \\
\hline Displacement & $\sim 16 \%$ & $\sim 20 \%$ \\
\hline
\end{tabular}

- Weight and energy methods no longer used.

- Some studies did not consider co-products at all. 

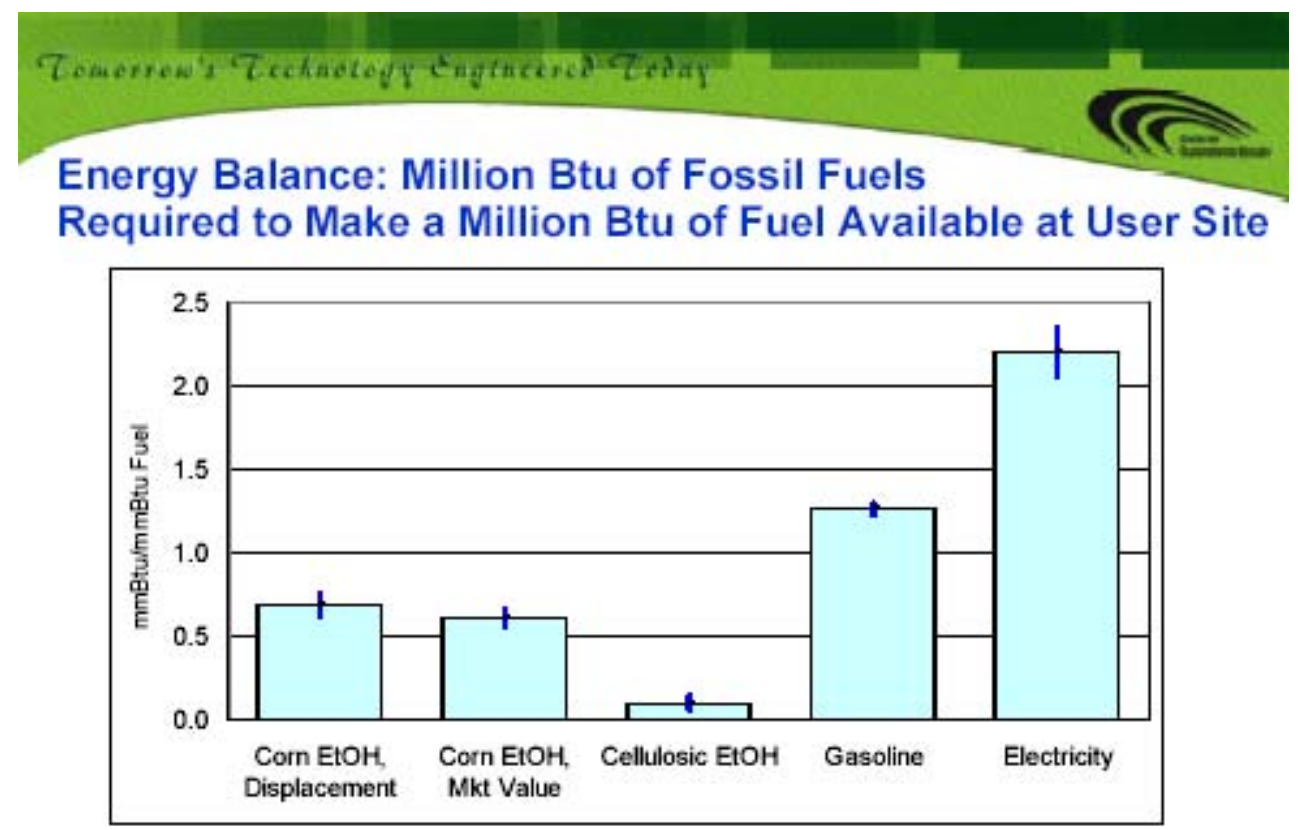

A problem with energy balance values is that the quality of a fuel is NOT taken into account!!!
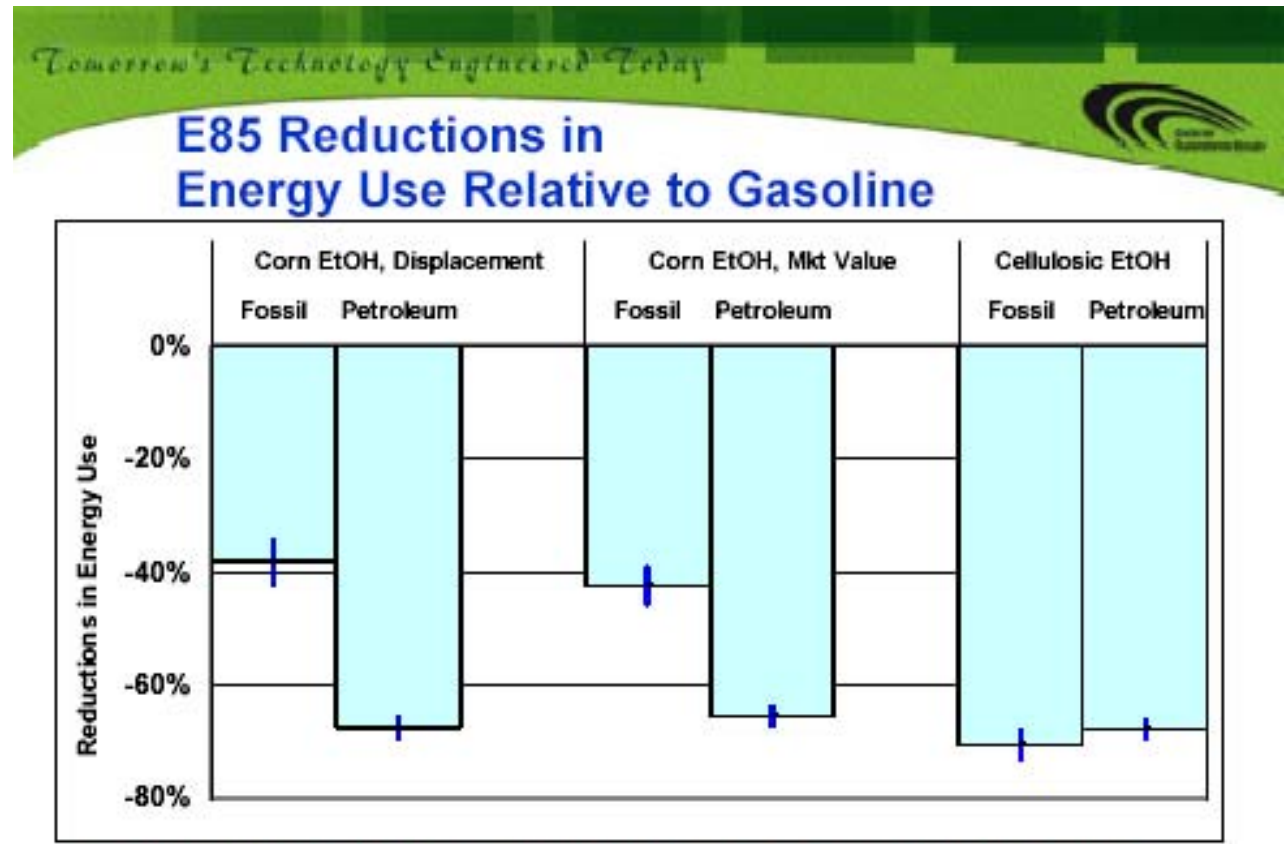

Note: Based on per-mile results of E85 use in FFVs. Fossil fuels here include petroleum, natural gas, and coal. 

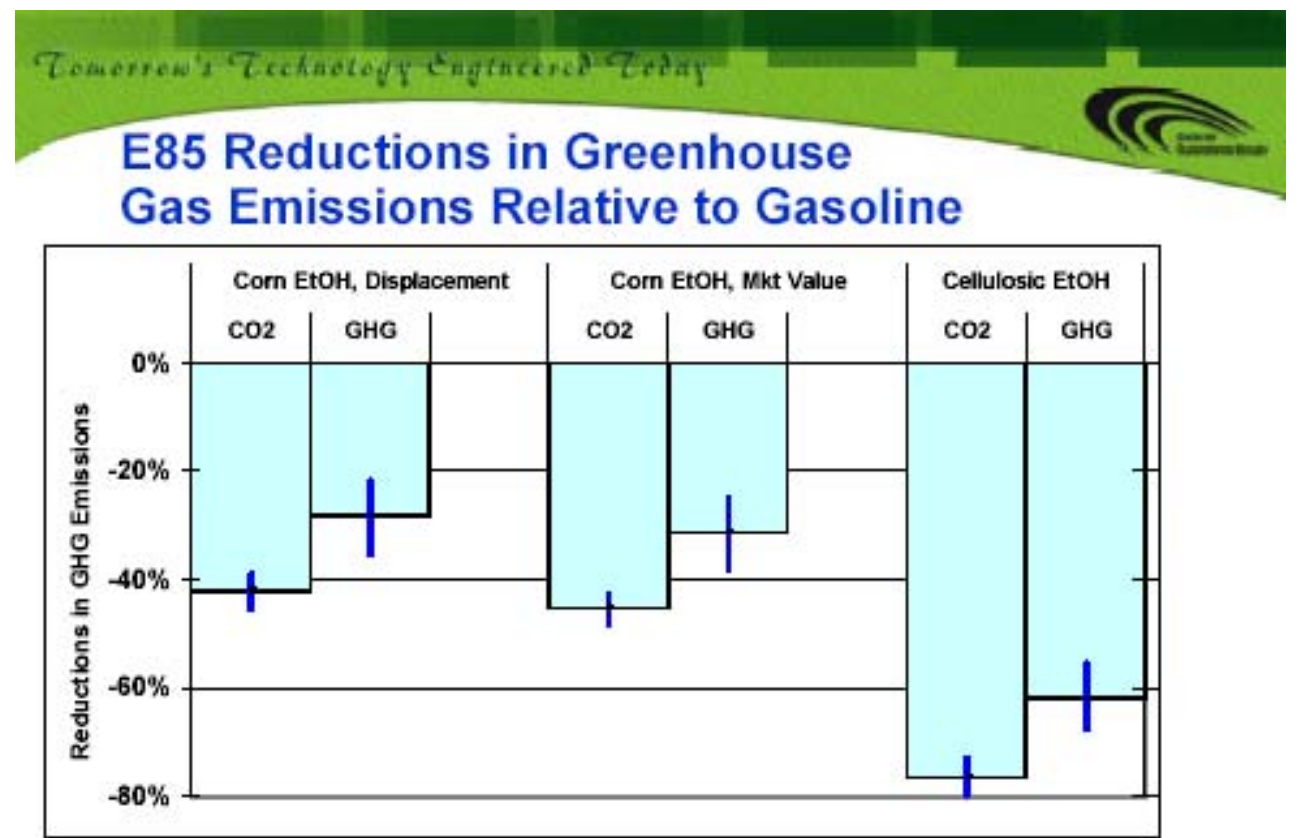

Note: Based on per-mile results of E85 use in FFVs. GHG emissions are CO2equivalent emissions of $\mathrm{CO} 2, \mathrm{CH} 4$, and $\mathrm{N} 2 \mathrm{O}$.

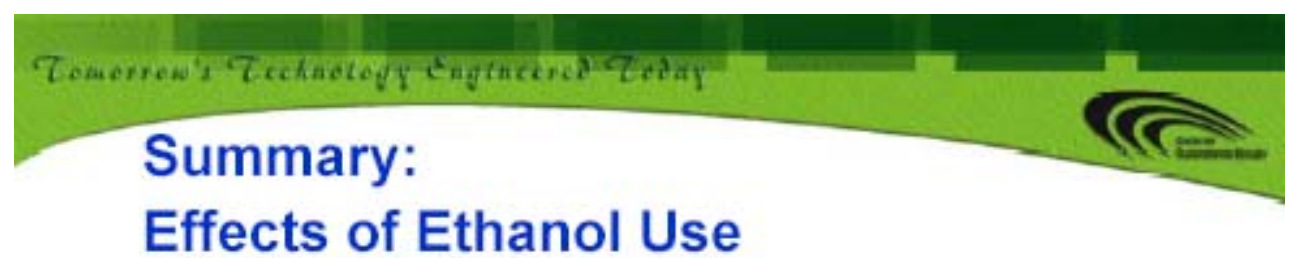

- Any type of fuel ethanol helps substantially reduce transportation's fossil energy and petroleum use.

- Corn-based fuel ethanol achieves moderate reductions in $\mathrm{GHG}$ emissions.

- Cellulosic ethanol will achieve much greater energy and GHG benefits. 


\title{
NET ENERGY OF ETHANOL FROM CORN: A Comparative Analysis
}

\author{
Bruce E. Dale \& Seungdo Kim \\ Dept. of Chemical Engineering \& Materials Science \\ Michigan State University \\ Presented at the: \\ Energy and Environmental Studies Institute \\ Congressional Briefing \\ Washington, D. C., July 31, 2002
}

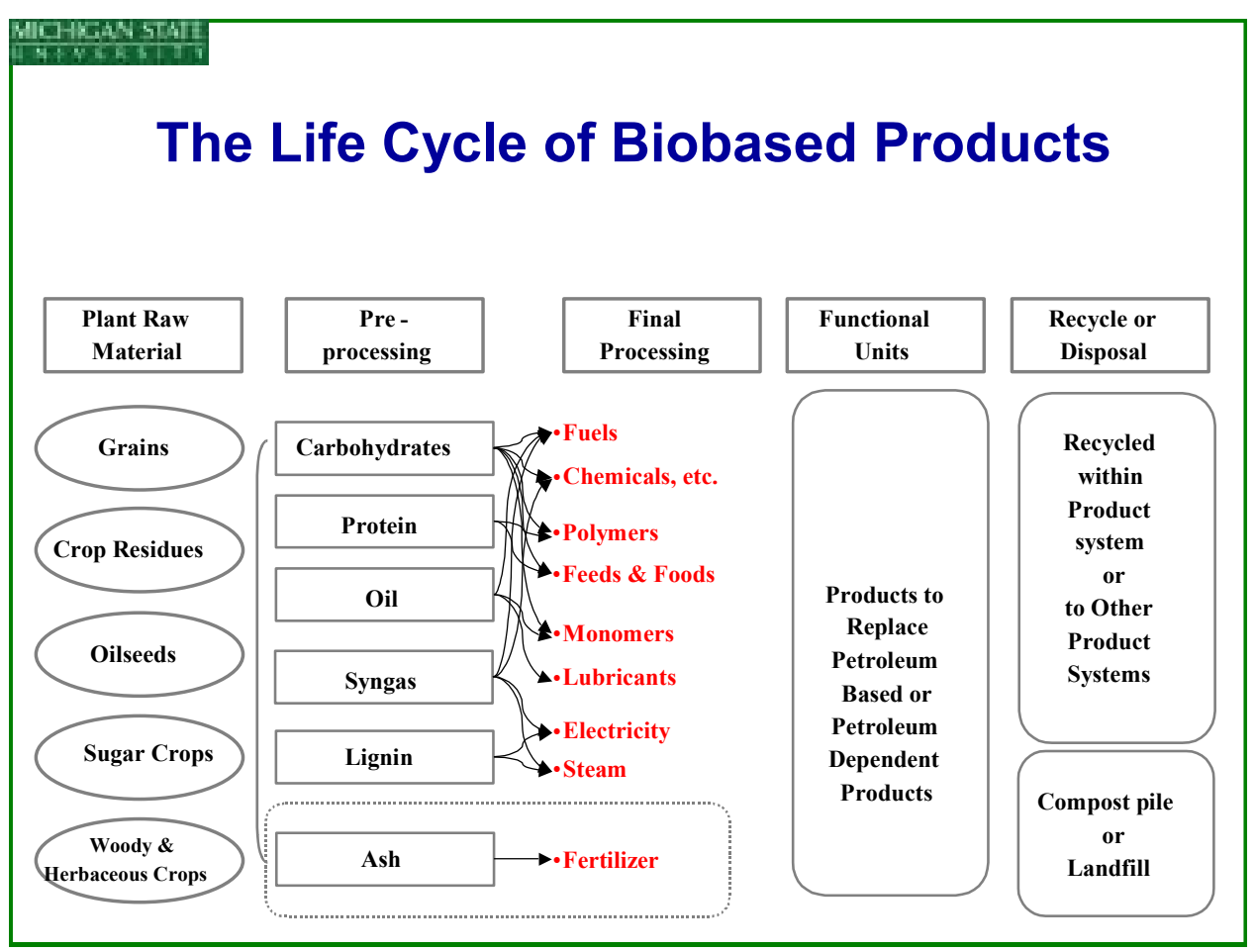




\section{Some Life Cycle Analysis Standards:} In Plain English

- Use the most recent data possible

- Make it easy for others to check your data and methods= transparency

- Set clear system boundaries: what exactly are we comparing?

- Multi-product systems must allocate environmental costs among all products

- Perform sensitivity analysis: how much do results vary if assumptions or data change?

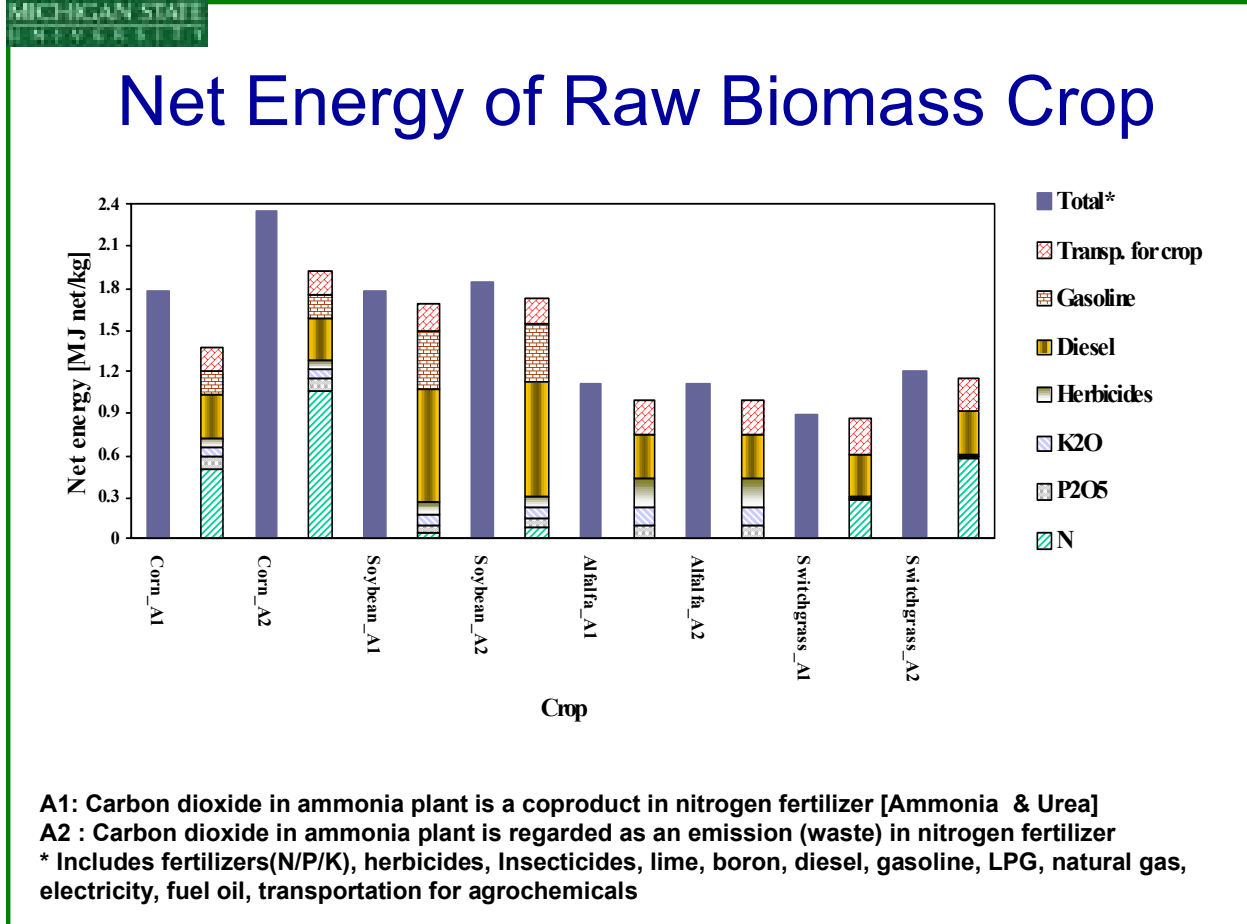




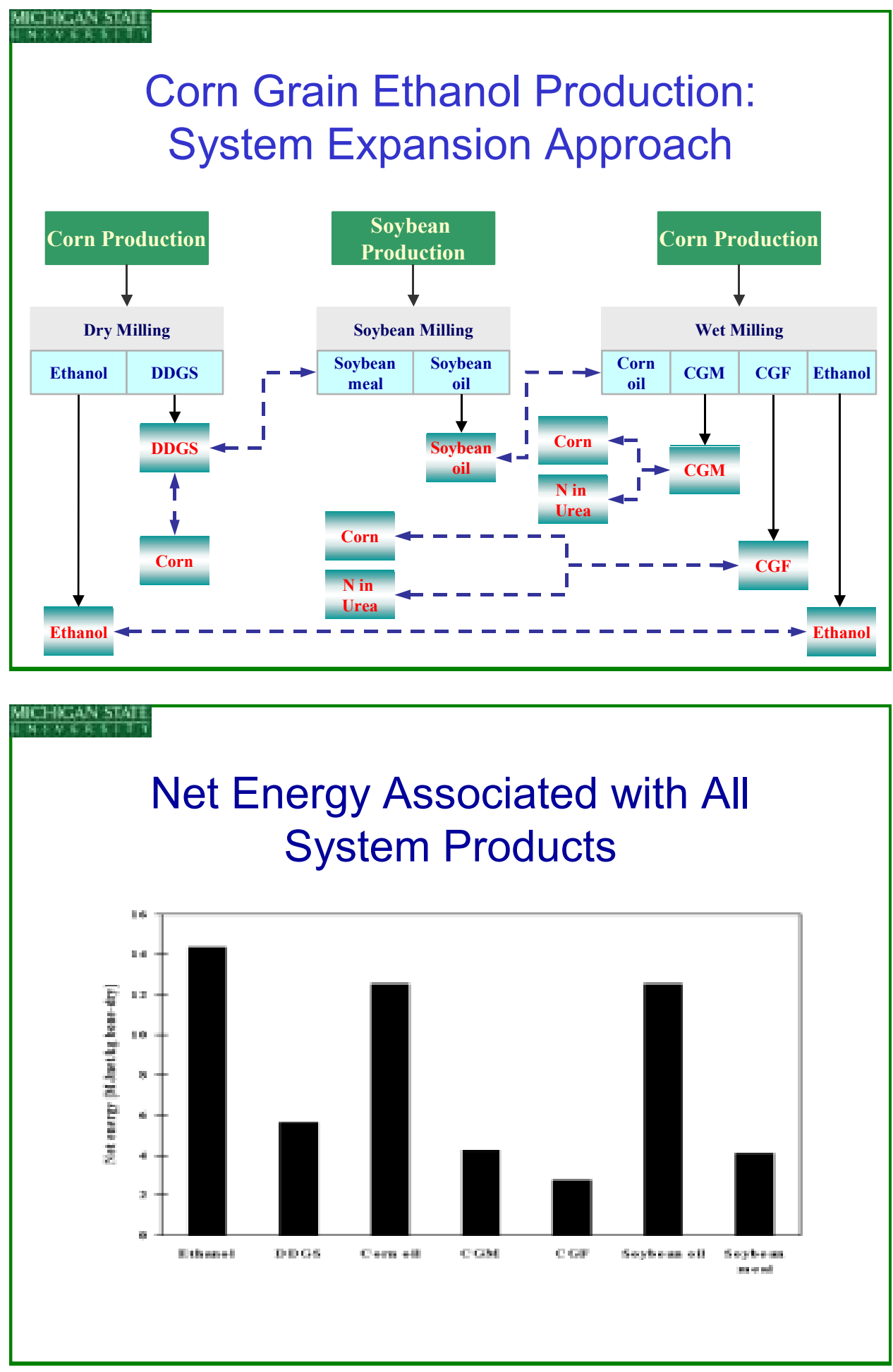




\section{And What is the Result?}

- Net energy is approx. 0.4 units per unit of ethanol produced

- Therefore corn ethanol production is a net energy winner

- Results are most affected by (sensitive to):

- Allocation methods

- Dry \& wet milling process energy

- Corn production

\section{Who Else Thinks Corn Ethanol is a Net Energy Winner?}

- Nearly everyone who has studied the issue:

- Wang (1999)

- Shapouri (1995 \& 2002)

- Graboski (2001)

- Lorenz (1995)

- Agriculture Canada (1999)

- Kim and Dale (2002)

- Except for Prof. Pimentel 


\section{Ethanol Net Energy Value: Summary of Studies}

\begin{tabular}{|l|c|}
\hline Authors and Date & NEV [Btu] \\
\hline Pimentel (1991) & $-33,517$ \\
\hline Pimentel (2001) & $-33,562$ \\
\hline Keeney and DeLuca (1992) & $-8,438$ \\
\hline Marland and Turhollow (1990) & 18,154 \\
\hline Lorenz and Morris (1995) & 30,589 \\
\hline Ho (1989) & $-4,000$ \\
\hline Agri.and Agri-Food, CAN (1999) & 29,826 \\
\hline Wang et al. (1999) & $\mathbf{2 2 , 5 0 0}$ \\
\hline Shapouri et al. (1995) & $\mathbf{2 0 , 4 3 6}$ \\
\hline Kim and Dale (2002) & $\mathbf{2 3 , 8 8 6 - 3 5 , 4 6 3}$ \\
\hline
\end{tabular}

\section{So Why Does Prof. Pimentel Say Otherwise?}

- His corn yields date from 1992

- His figures for energy required to produce ethanol and the ethanol yield date from 1979

- His figures for energy to produce fertilizer are 1990 world values per FAO—not recent U.S. values

- He assumes all corn is irrigated (only $16 \%$ is)

- And anyway: virtually no irrigated corn is converted to ethanol

- He does not assign an energy credit for the high protein DDGS coproduct 


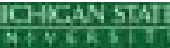

\section{Comparing Pimentel's Work with Some Life Cycle Analysis Standards}

- Does he use recent data? ...Absolutely not

- Is his work transparent? ... No, he is very difficult to follow

- Are clear system boundaries set?...No (irrigation, fertilizer, corn production region)

- Are energy inputs allocated among products?...No

- Does he perform a sensitivity analysis?...No

- But that is not the worst of it

\section{Net Energy is not the Most Important Question Anyway}

- No process can produce more energy than the energy that goes into it (Laws of Thermodynamics)

- The U.S. has ample energy in the form of coal and natural gas

- Corn ethanol essentially converts coal \& natural gas into a liquid fuel-which we do not have in abundance

- The question we should be asking is: "Is there a net displacement of oil in corn ethanol production?"

- Clearly the answer is yes-probably by at least $6 x$ 


\section{Net Energy of Electricity}

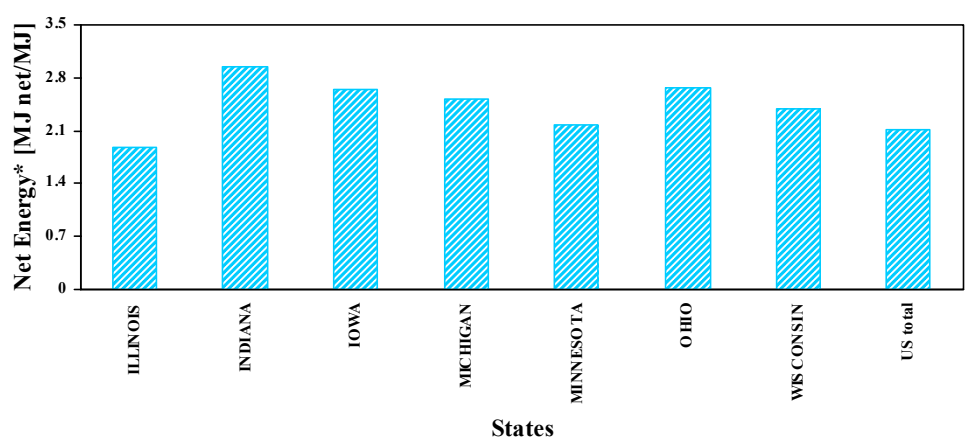

* Includes coal, natural gas, fuel oil, and nuclear, excludes hydropower

\section{Thank you for listening to me: now let's talk}


Professor Bruce E. Dale

Dept. of Chemical Engineering

\& Materials Science

Michigan State University

Phone 517-353-6777

Fax 517-432-1105

bdale@egr.msu.edu 


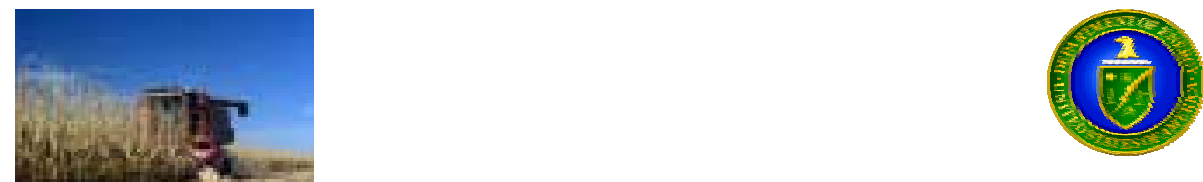

\section{Biodiesel from soybeans Ethanol from corn stover}

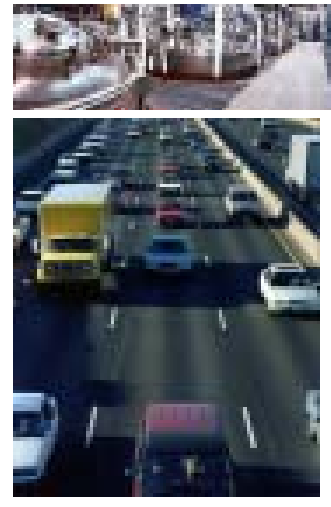

\section{Biofuels Briefing}

July 31, 2002

John Sheehan

National Renewable Energy Laboratory

\section{Outline}

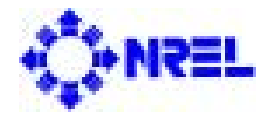

- Biodiesel

- What is it?

- Fossil energy and petroleum savings

- Climate change and air quality impacts

- Ethanol from Corn Stover

- Why ethanol from corn stover?

- Fossil energy and petroleum savings

- Climate change and air quality impacts

- How much cellulosic ethanol can we make? 


\section{What is biodiesel?}

- 20 million gallon per year industry in the US

- Recipe:

- 1 part soybean oil

- 3 parts methanol

- Add a dash of alkaline catalyst

- Yields 3 biodiesels and 1 glycerine

- Other renewable diesels

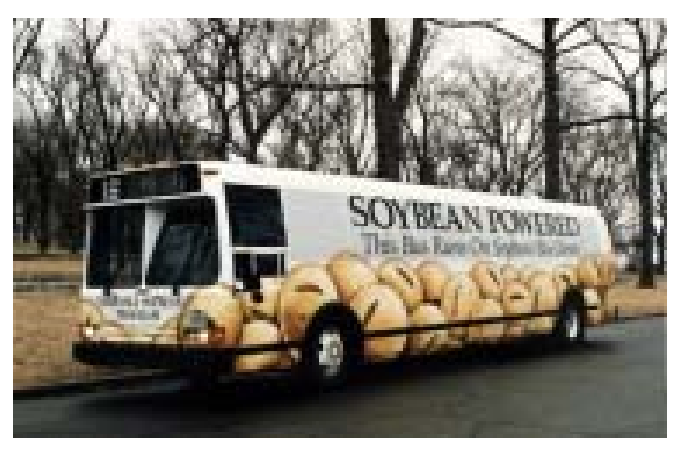

\section{Biodiesel-}

\section{from field to tailpipe}

Biodiesel

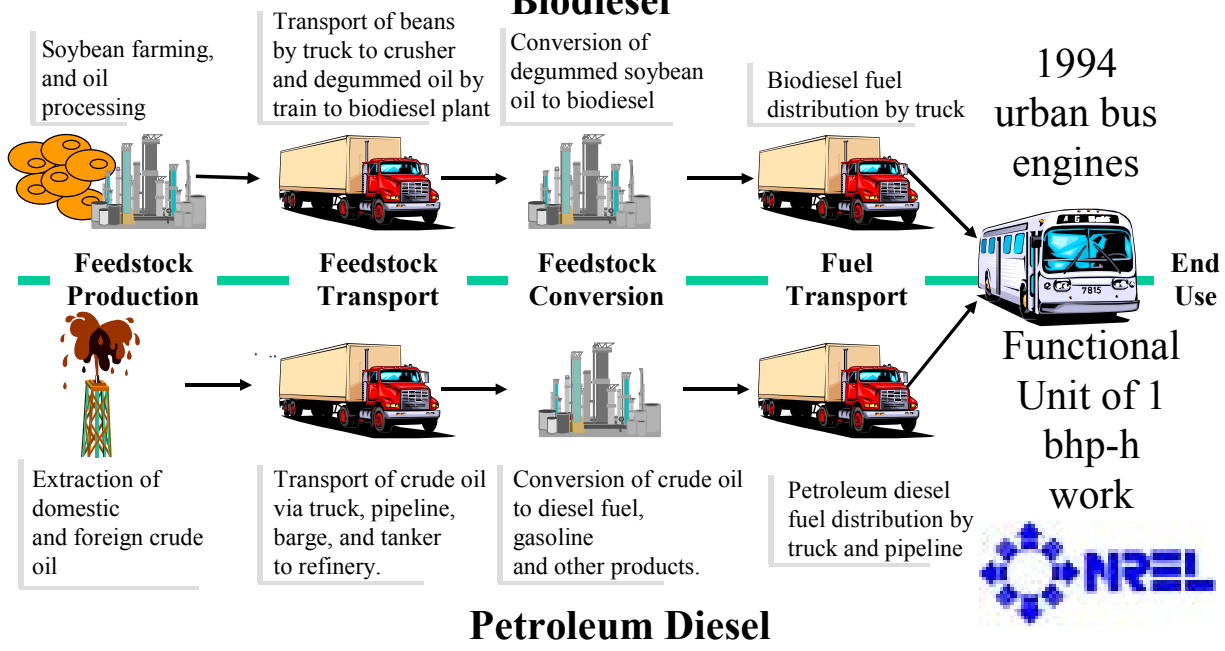




\section{Fossil fuels-leveraging non-renewable energy}

- Biodiesel yields 3.2 units of fuel energy for every unit of fossil fuel consumed in its life cycle.

- Petroleum diesel yields 0.83 units of fuel energy per unit of fossil energy consumed.

- Biodiesel reduces fossil energy consumption by $75 \%$ compared to diesel

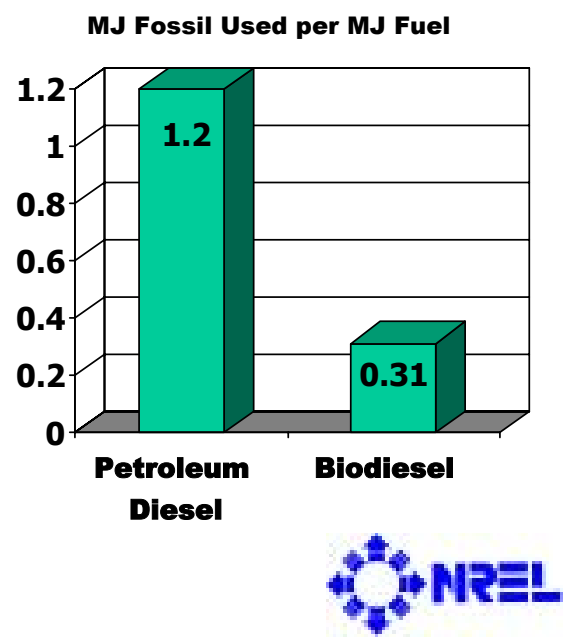

$\mathrm{CO}_{2}$-mitigating

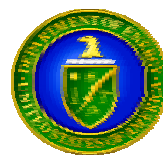
greenhouse gases

g CO2 per bHP-h of work

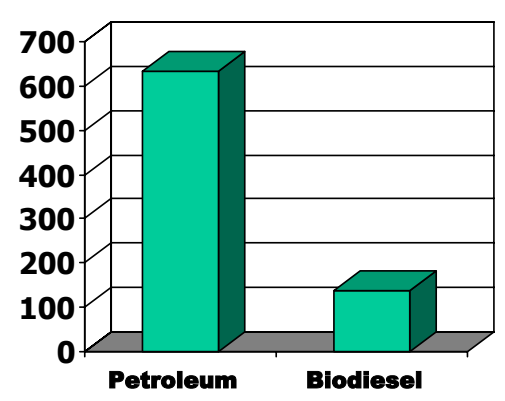

- Biodiesel emits $78.5 \%$ less $\mathrm{CO}_{2}$ than petroleum diesel

- Blends exhibit proportionate benefits

- B20 emits 15.66\% less $\mathrm{CO}_{2}$ than petroleum diesel 


\section{Air emissions-significant $\mathrm{CO}$ reductions}

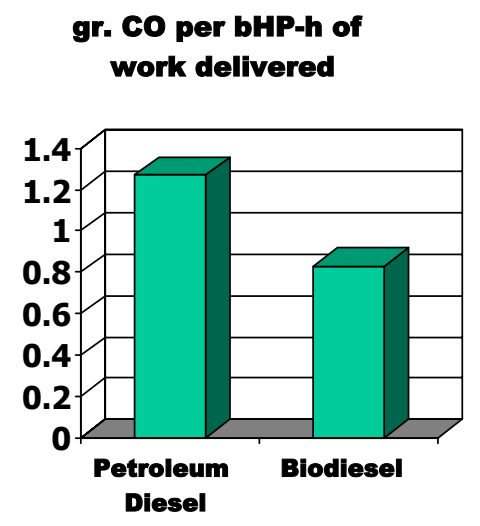

- Life cycle emissions of CO are $34 \%$ lower for neat biodiesel.

- B20 has 7\% lower emissions.

- Reductions primarily at the tailpipe

\section{Air emissions-significant PM benefits}

- Life cycle emissions of total particulate matter are 32\% lower for neat biodiesel

- B20 can reduce life cycle emissions of total particulate matter by $6.5 \%$

- Reductions primarily at the tailpipe

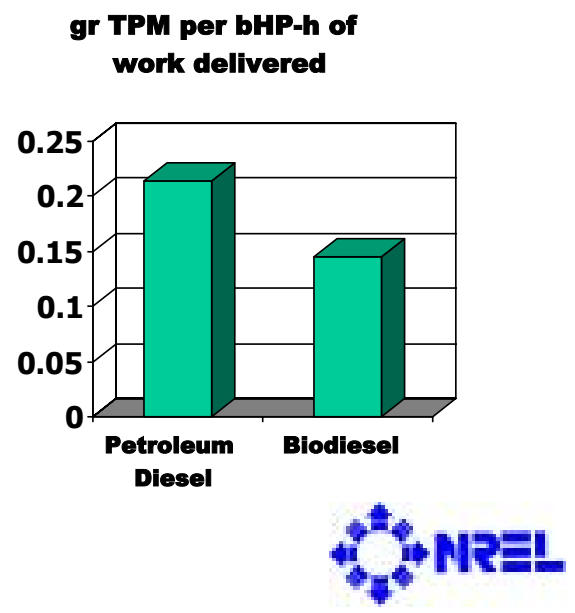




\section{Air Emissions-SOx}

gr. SOx per bHP-h of work delivered

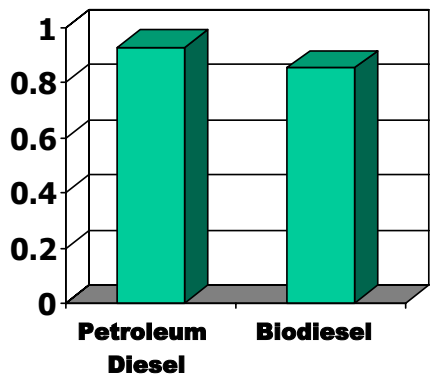

- B100 reduces Life cycle emissions of $\mathrm{SO}_{\mathrm{x}}$ by $8 \%$

- B20 reduces life cycle emissions of $\mathrm{SO}_{\mathrm{x}}$ by $1.6 \%$

- Zero emissions at tailpipe offset by $\mathrm{SO}_{\mathrm{x}}$ from electricity, steam and natural gas use

- $\mathrm{SO}_{\mathrm{x}}$ from natural gas production may be overestimated

- assumed that sulfur removed is all released as $\mathrm{SO}_{x}$

\section{Air emissions-HC increases with biodiesel}

- Life cycle emissions of total hydrocarbons are 35\% higher for B100

gr. THC per bHP-h of work delivered

- Reduced tailpipe emissions for biodiesel are offset by emissions of

- hexane in soy oil processing

- volatilization of agricultural chemicals

- $\mathrm{HC}$ emissions are potentially shifted out of urban areas

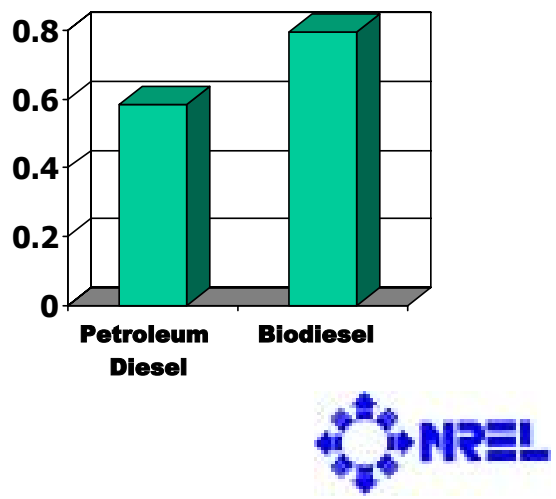




\section{Air emissions- $\mathrm{NO}_{\mathrm{x}}$ increases with biodiesel}

- B100 has life cycle emissions of $\mathrm{NO}_{x}$ that are $13.35 \%$ higher than those of petroleum diesel.

- The majority of the $\mathrm{NO}_{\mathrm{x}}$ in biodiesel's life cycle comes from increased emissions at the tailpipe.

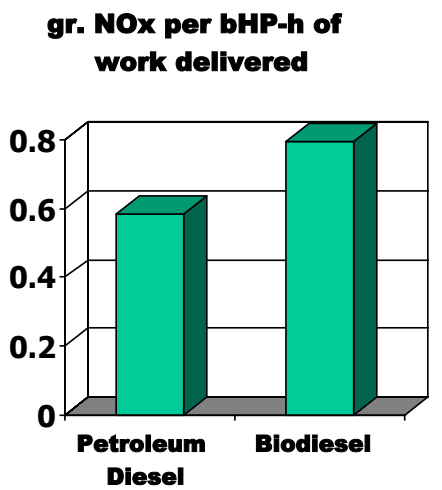

\section{Life cycle impacts of using biodiesel}

- 3.2-to-1 leveraging of fossil fuel (coal, oil and natural gas)

- $95 \%$ reduction in petroleum consumption

- $78 \%$ reduction in $\mathrm{CO}_{2}$ emissions

- Reductions in air emissions for total particulates (32\%), $\mathrm{CO}(35 \%)$ and $\mathrm{SO}_{\mathrm{x}}(8 \%)$

- Increased emissions of $\mathrm{NO}_{x}(13.35 \%)$

- Increased total hydrocarbon emissions (35\%) 


\section{Why ethanol from corn stover?}

- $85 \%$ of the residue left after grain harvest (stover) rots on the ground releasing $\mathrm{CO}_{2}$

- The other $15 \%$ is incorporated in soil as organic matter

- DOE posits that a certain amount of residue can be collected and used for ethanol production

- Our life cycle study asks if the benefits of carbon recycling and fossil energy avoidance can be properly balanced against the lost opportunity for sequestering carbon in soil and improving soil health

- We do this by bringing soil science into the life cycle equation

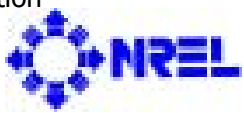

\section{Life cycle analysis-corn stover vs petroleum in Iowa}

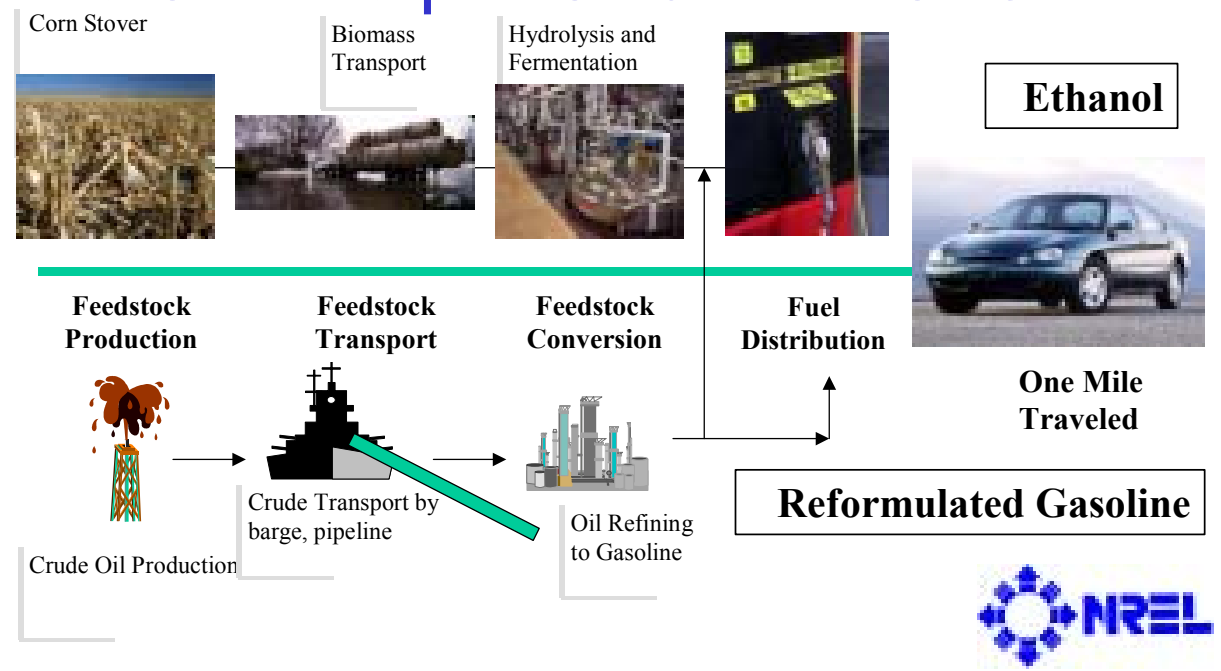




\section{Ethanol from stover reduces fossil energy use by $102 \%$}
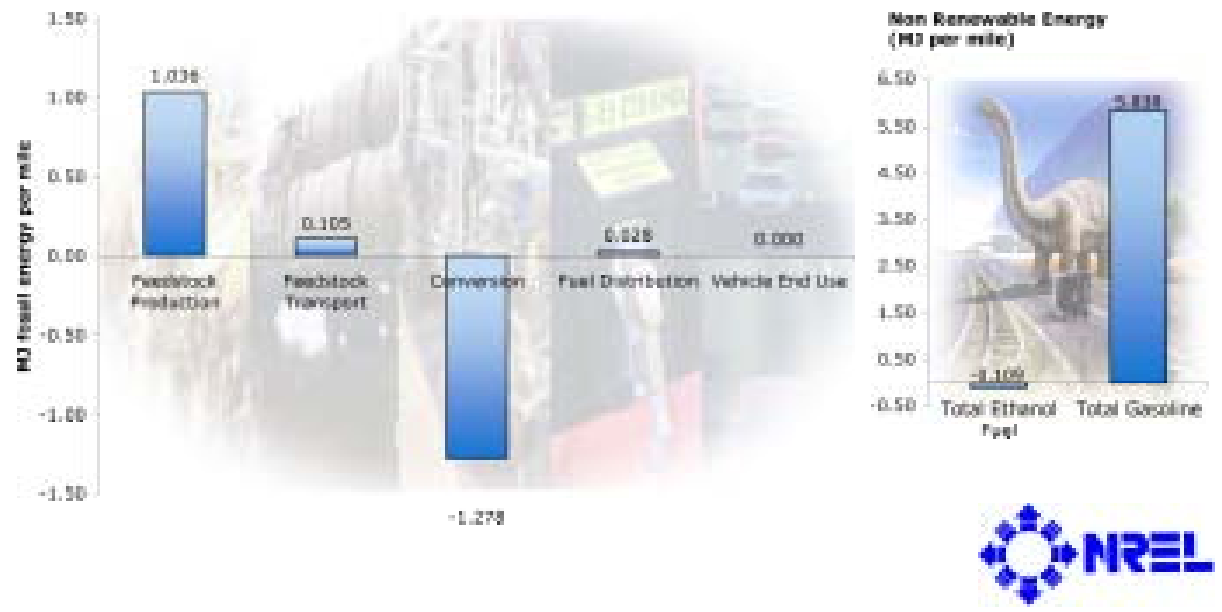

\section{Ethanol from stover reduces petroleum use by $95 \%$}
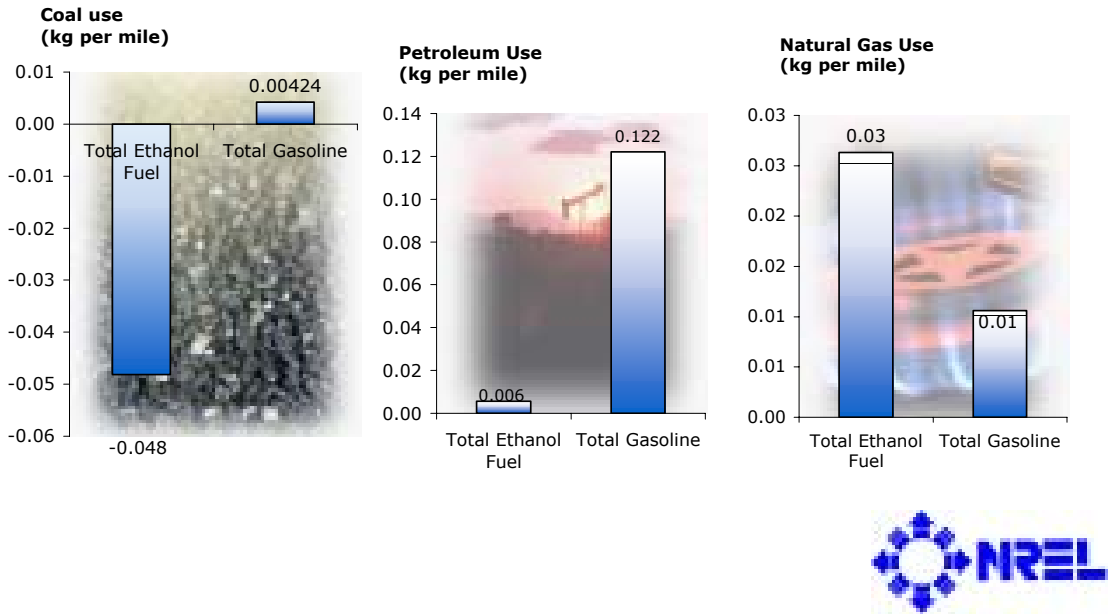


\section{Responsible collection of stover can protect soil health}

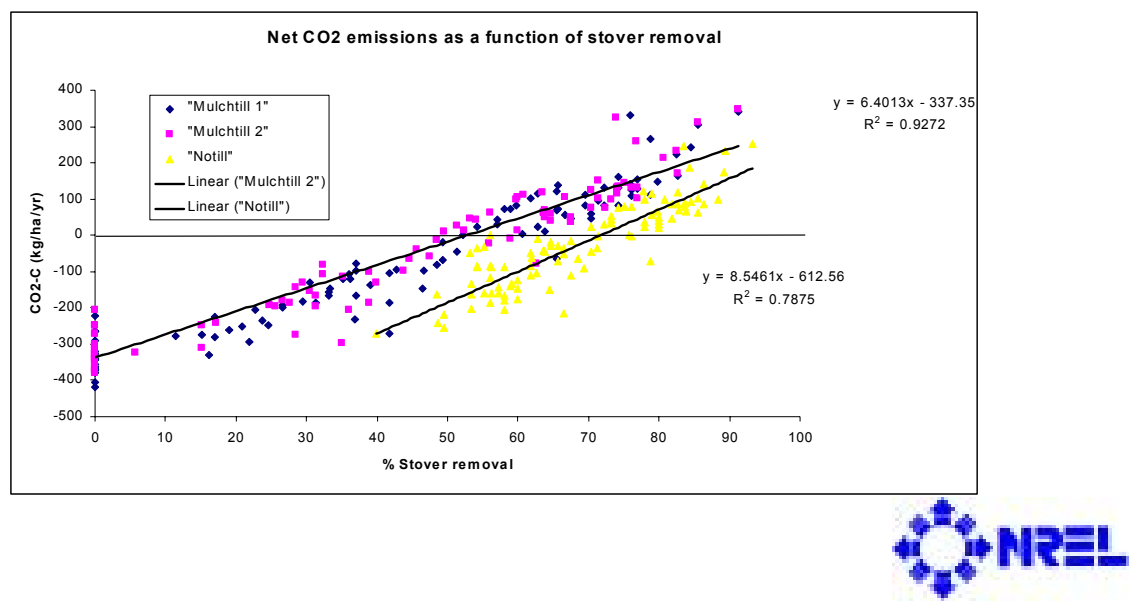

\section{Ethanol from stover reduces greenhouse gas emissions}

by $110 \%$
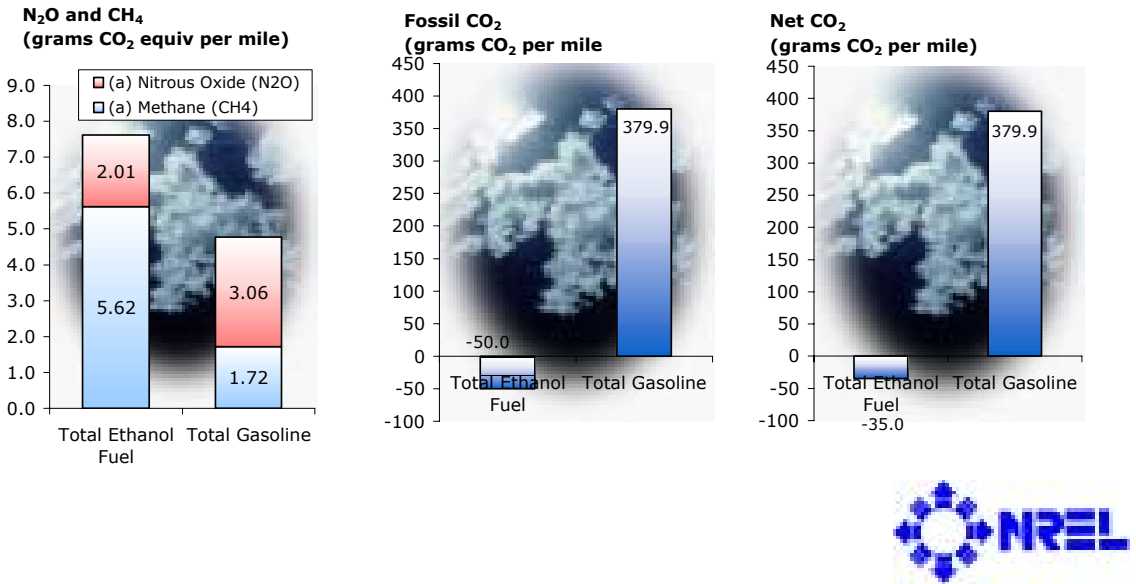


\section{We still have questions about ethanol's air quality impacts}
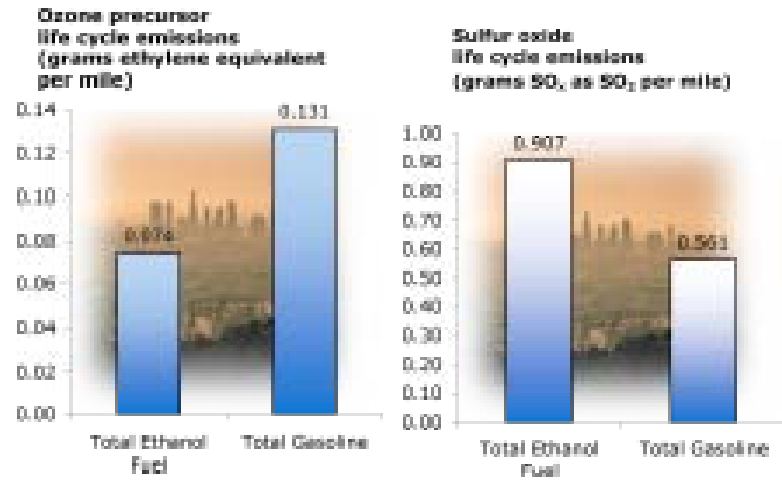

Witropen exode

(grame NO, an NO, per mile)
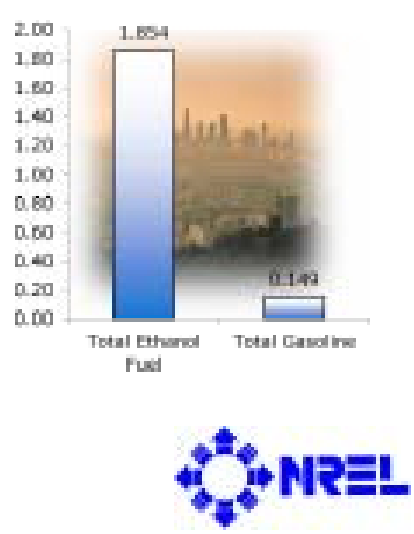

\section{Land area required: the effect of vehicle efficiency (U.S. light duty vehicles)}

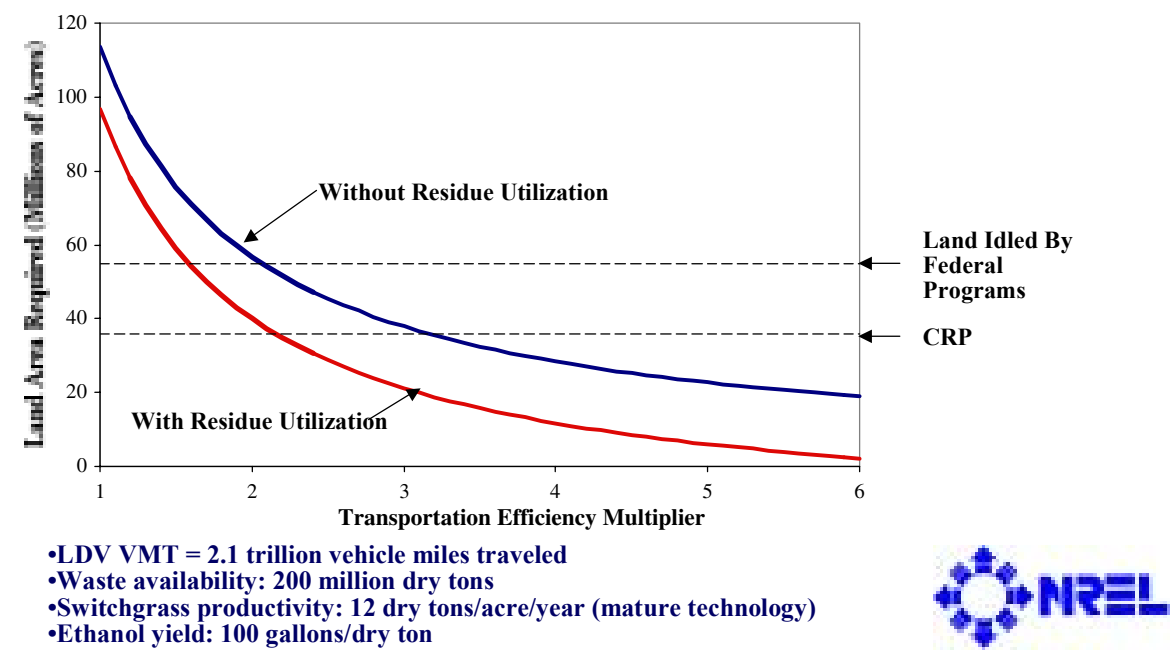




\section{Is ethanol from corn stover sustainable?}
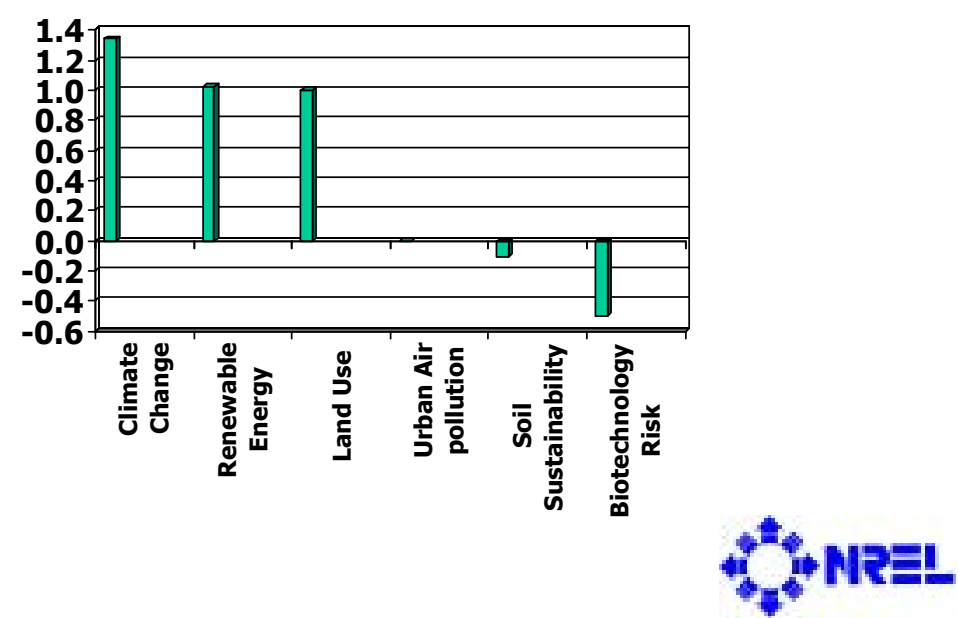


\section{Appendix III \\ Speaker materials for briefing II - \\ "Enacting a Renewable Fuels Standard: Economic, Energy, and Environmental Implications"}




\section{Enacting a Renewable Fuels Standard: Economic, Energy, and Environmental Implications}

\section{Environmental and Energy Study Institute (EESI) \\ Congressional Briefing \\ 2318 Rayburn House Office Building \\ March 27, 2003}

NESCAUM

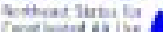

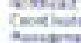

Ken Colburn

NESCAUM

kcolburn@nescaum.org

\section{MtBE: How Did We Get Here? (1)}

- Oxygenate used since 1970 s to enhance octane after lead removed; average concentration 2-3\%

- Cleaner burning reformulated gasoline (RFG) introduced in 1995; average concentration 11\%

- Due to ozone nonattainment SIP requirements, Northeast gasoline now $75 \%$ RFG

- Substantial air quality benefits

- EPA: $27.4 \%$ VOC, $6.8 \%$ NOx, $24 \%$ benzene, $21.5 \%$ toxics, etc.

- Actual results even better, e.g., 27-35\% toxics 


\section{MtBE: How Did We Get Here? (2)}

- MtBE highly mobile \& persistent; significant groundwater contamination found after 1997

- MtBE now one of the most widely detected contaminants in Northeast drinking water

- Not just LUSTs (leaking pipelines, spills, accidents, two-cycle engines, stormwater runoff, etc.)

- Intense public concern over smell, taste, carcinogenicity

- CAA 2\% "oxygen mandate" constrains states

- MtBE-or-ethanol for practical purposes

- Waivers difficult and/or politically impossible

- States condemned to contaminate water?

\section{Bottom Line Status Quo}

- "Just Say No" to MtBE is not an option under current law

- Stick:

- State MtBE bans with CAA 2\% oxygen mandate

- EIA estimates as much as three times more ethanol will be used in Northeast under status quo

- Status quo would force summertime ethanol use

- Or, continued contamination of drinking water supplies

- Carrot:

- RFS is a relatively gentle, market-based approach 


\section{RFS Addresses Northeast Concerns Well (1)}

- Environmental:

- 2\% CAA oxygen mandate lifted

- MtBE phased out \& banned

- No backsliding on actual air quality gains to date

- Clarifies state authority; enables OTC-wide fuel

- Economic:

- Volume: RFS $=1 / 3$ of ethanol required by $2 \%$ CAA oxygen mandate

- Price \& Supply: Refiner/distributor flexibility on when and where ethanol is blended

- Lead time and fuel fungibility (vs. "boutique" fuels) far better than state-by-state action

\section{RFS Addresses Northeast Concerns Well (2)}

- Environmental:

- Greenhouse Gases (GHG):

- Cellulosic-based ethanol reduces GHG up to $100 \%$ compared to gasoline (Argonne)

- Corn-based ethanol blend (E-10) reduces GHG by $12-19 \%$

- Economic:

- Encourages cellulosic ethanol (1.5:1 credit)

- Northeast feedstocks could support 50 15-MGPY plants; with associated renewable power $=>\sim 11,000$ jobs

- Rural boost: market for paper sludge, low-grade wood (chips), agricultural \& municipal waste

- Potential to improve domestic energy supply \& security 


\section{Concerns Regarding RFS Legislation}

- Careful implementation needed due to RVP (volatility; co-mingling)

- Minor technical fixes may be appropriate:

- Refinery-by-refinery toxics baselines

- Possible change to waiver processing language

- Would welcome fate and transport study

- Potential Deal Killers:

- Liability "Safe Harbor" for MtBE

- No ban on the use of MtBE in gasoline 


\section{Masada OxyNol}

Finally, A Smart

Clean Solution

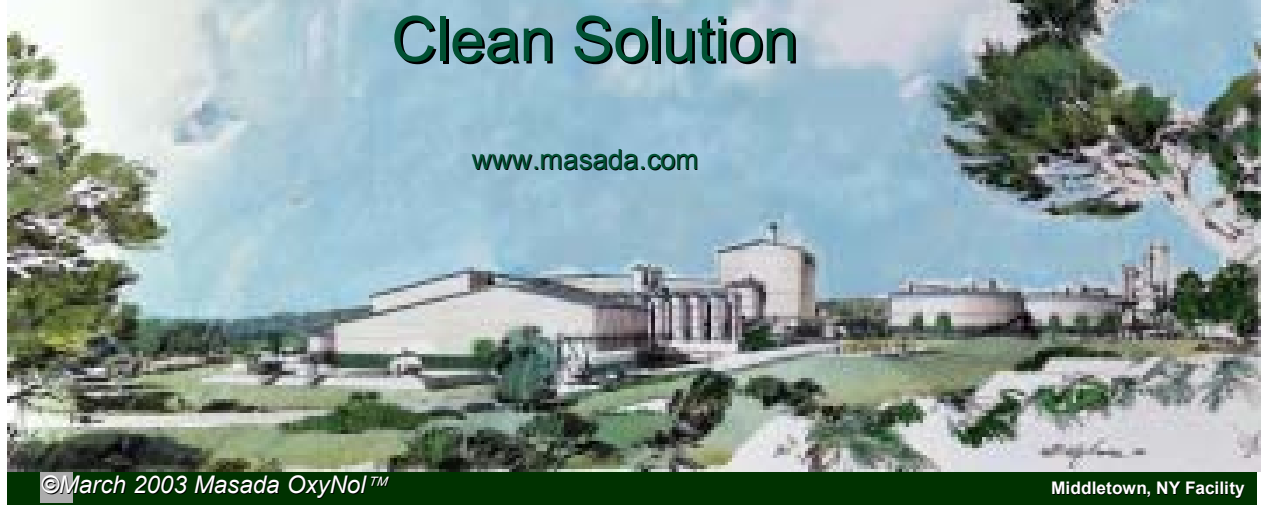

\section{Innovative Process}

Masada OxyNo/TM, together with the U.S. Department of Energy, Tennessee Valley Authority (TVA) and National Renewable Energy Lab (NREL) have developed a process that converts Municipal Solid Waste and Sewage Sludge to fuel ethanol and other commercial by-products. 

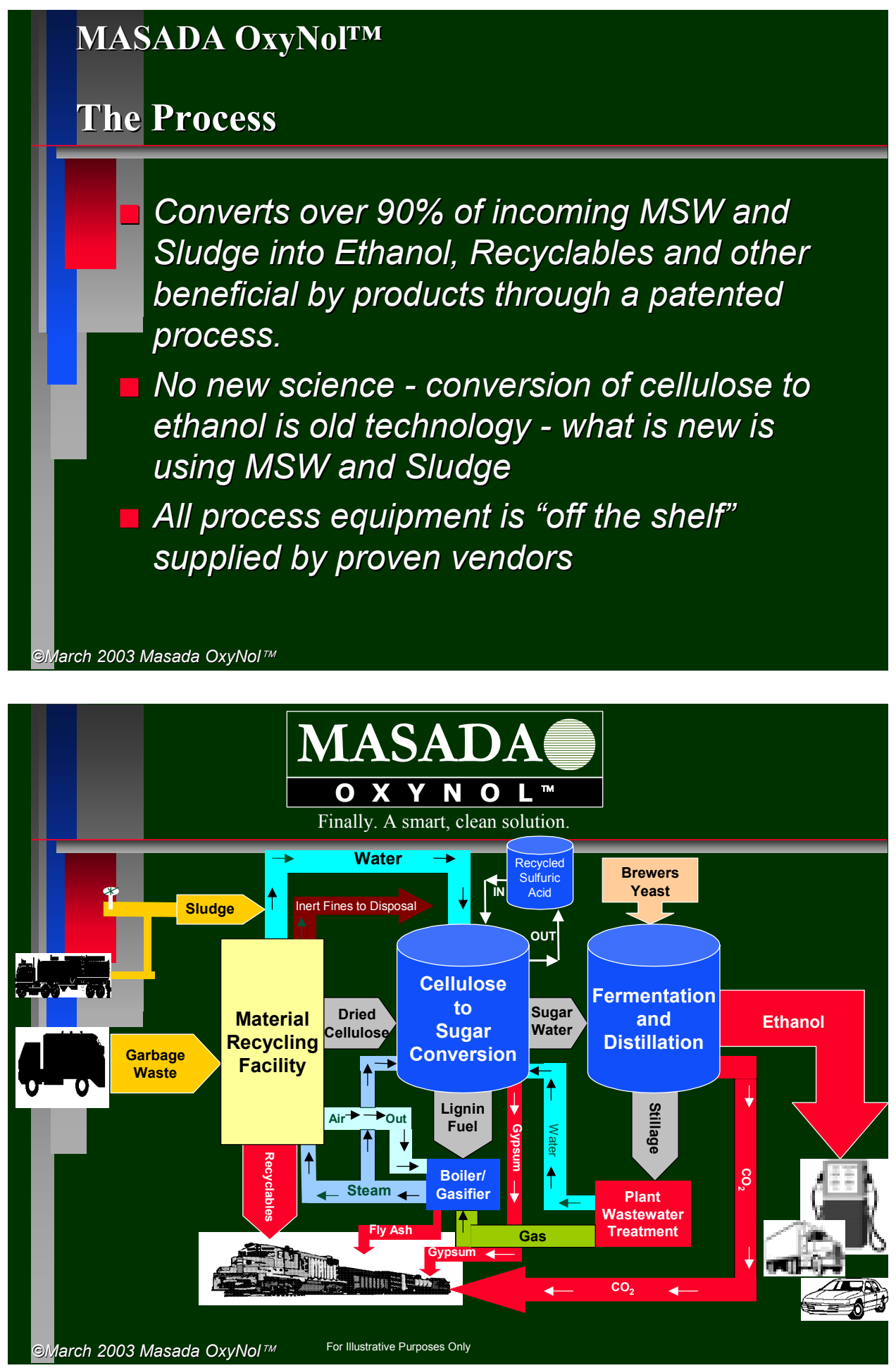


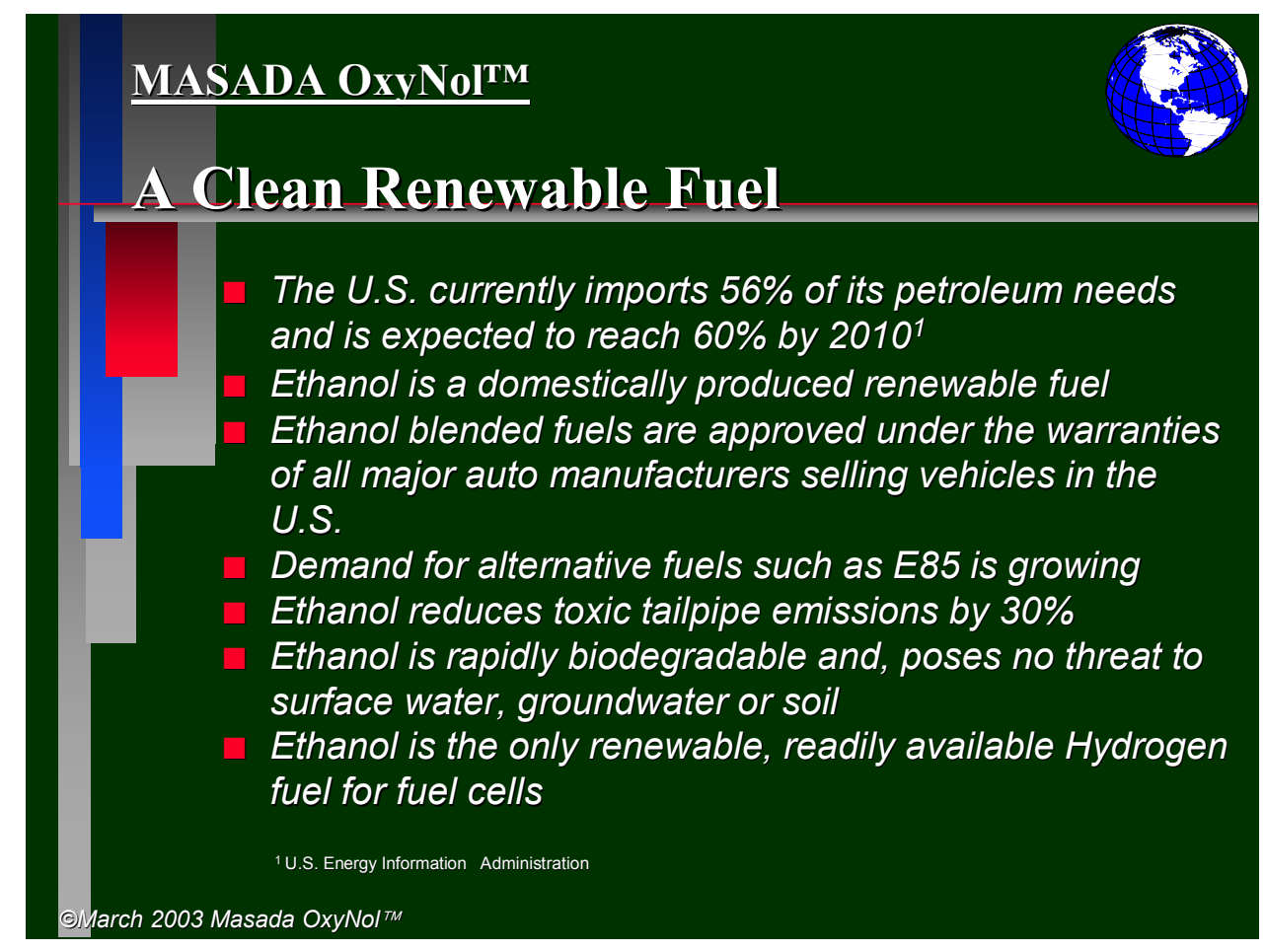

\section{Proposed Renewable Fuel Standard}

Supported by the Administration

Promotes national energy security by

reducing crude oil imports by 1.6 billion

barrels by 2012

$\square$ Protects the environment by reducing toxic tailpipe emissions

$\square$ Provides flexibility for refiners

$\square 1$ gallon of cellulosic ethanol is equivalent to 1.5 gallons of renewable fuel 


\section{Cellulosic Ethanol}

$\square$ Important component of RFS

$\square$ Wide variety of feedstocks available MSW to agricultural wastes

MSW to ethanol conversion provides ethanol to urban markets where it is most needed

- New York/Northern New Jersey need about 391 million gallons of ethanol to replace MTBE and to meet current CAA requirements - less than half of New York's garbage would meet this need.

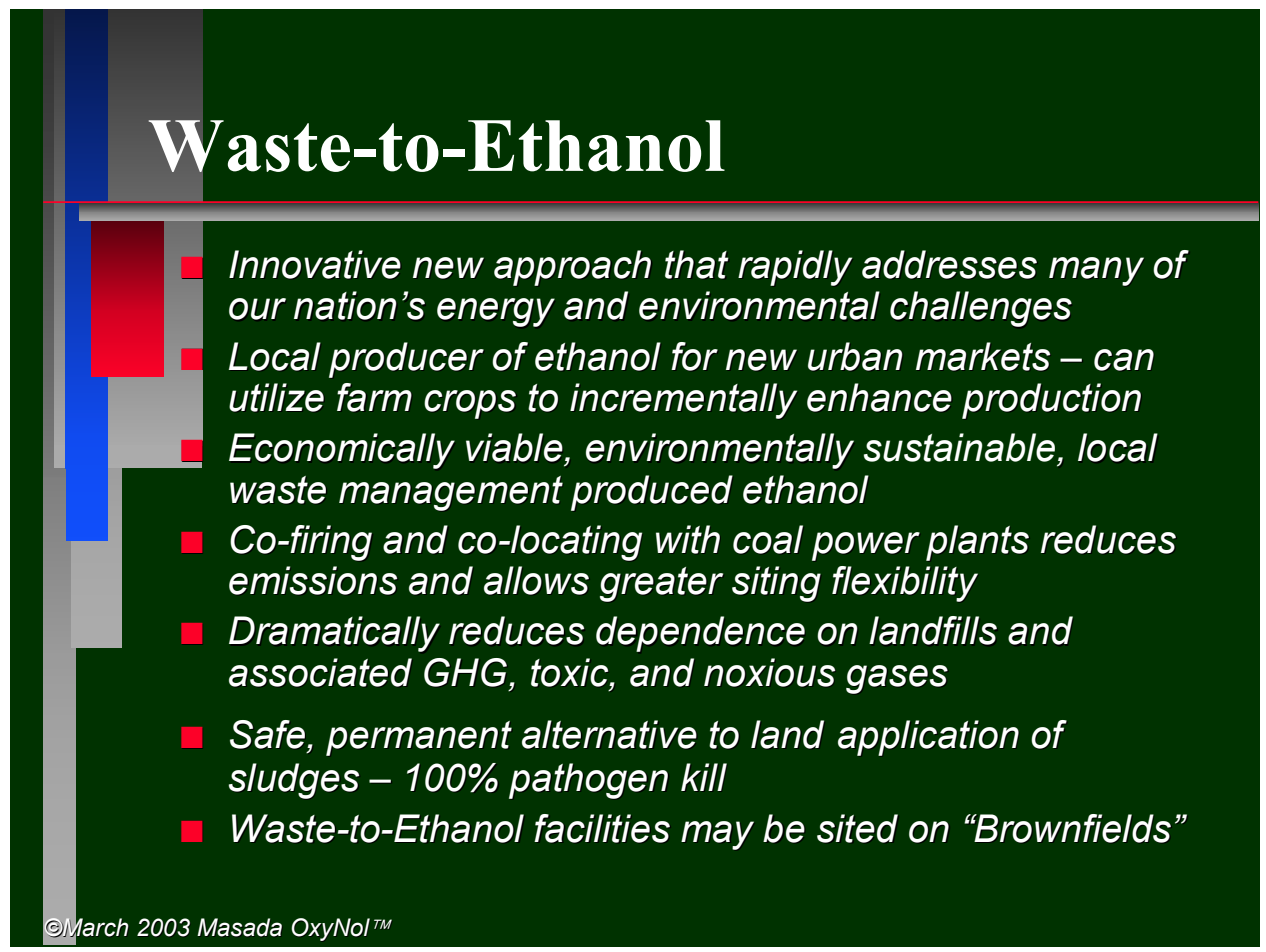




\section{Economic Benefits of MSW to Ethanol Facility}

\section{NATIONALLY}

Ethanol production currently provides more than 200,000 direct and indirect American jobs

- Ethanol production reduces the U.S. trade balance by $\$ 2$ billion annually

- A typical garbage-to-ethanol facility will create over 200 permanent jobs and 400-800 construction jobs

\section{NEW YORK}

- The Middletown facility will create up to 200 permanent jobs and 350 union construction jobs

- The Middletown facility will generate more than $\$ 30$ million per year in local contracts and salaries

- The Facility will provide municipal wastes disposal services to 24 municipalities 


\section{Assuring A Reliable Fuel $\underline{\text { Supply }}$}

Environmental and Energy Study Institute

March 27, 2003

Edward Murphy

Downstream General Manager

American Petroleum Institute

\section{BENEFITS OF THE COMPROMISE APPROACH}

- Address serious fuels problems affecting U.S. motorists

- Ensure flexibility in fuels policies

- Provide positive future for renewable fuels

- Maintain air quality benefits

- Serve best interests of American consumers 


\section{STATUS QUO MEANS HIGHER COSTS TO CONSUMERS}

- Consumers will be subject to costs of uncoordinated state MTBE bans

- 16 states have laws in place to phase down or ban MTBE - others likely to follow

- States cannot repeal federal RFG oxygen requirement - CA attempt to do so rejected by EPA

- Collision of state MTBE bans + federal oxygen requirement will mean higher costs and use of renewable fuels where not optimal

\section{STATE MTBE BANS}

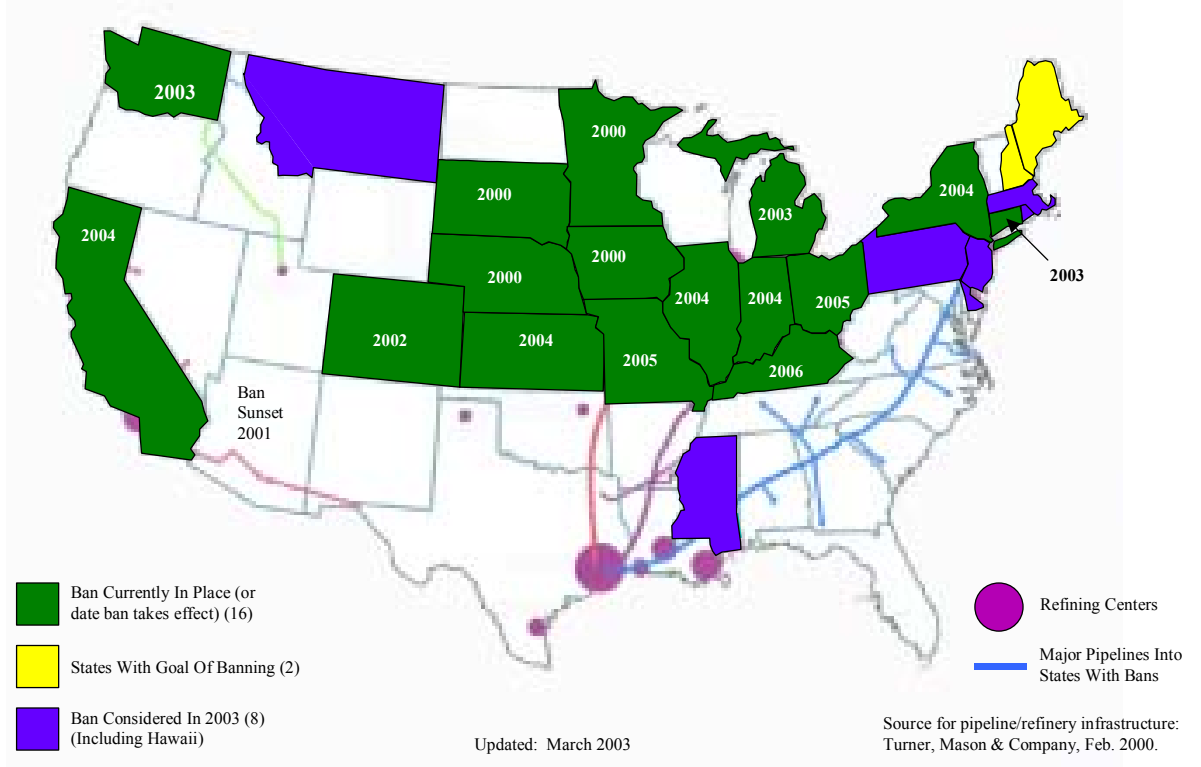




\section{NECESSARY FUELS CHANGES}

- Repeal of the Federal RFG oxygen requirement

- National program to significantly reduce the use of MTBE

- Maintain the environmental benefits of clean fuels programs

- Do not penalize industry for following will of Congress

- Respond to demands for renewable fuels in most efficient and beneficial ways $=$ ABT Program

\section{COST OF A RENEWABLE FUELS STANDARD}

- U.S. Energy Information Administration (EIA) concluded that average national cost increase of gasoline due to renewable fuels requirement in Senate bill compared with status quo - would be negligible: one-half to one-cent per gallon

- EIA indicated cost could be even less when banking/trading provisions are factored in 


\section{COST OF AN RFS (cont'd)}

- Mathpro analysis showed the cost of the RFS (with $2 \%$ repeal) would be 0.2 cents per gallon less than status quo

- Assumed national credit trading program, the use of cleaner fuels (RFG and low-RVP gasoline) in ozone nonattainment areas, and a national phase-out of MTBE

- Ethanol use would be $\mathbf{4 . 3}$ billion gallons in 2012 under status quo - 5 billion gallon with the RFS

\section{U.S. GASOLINE REQUIREMENTS}

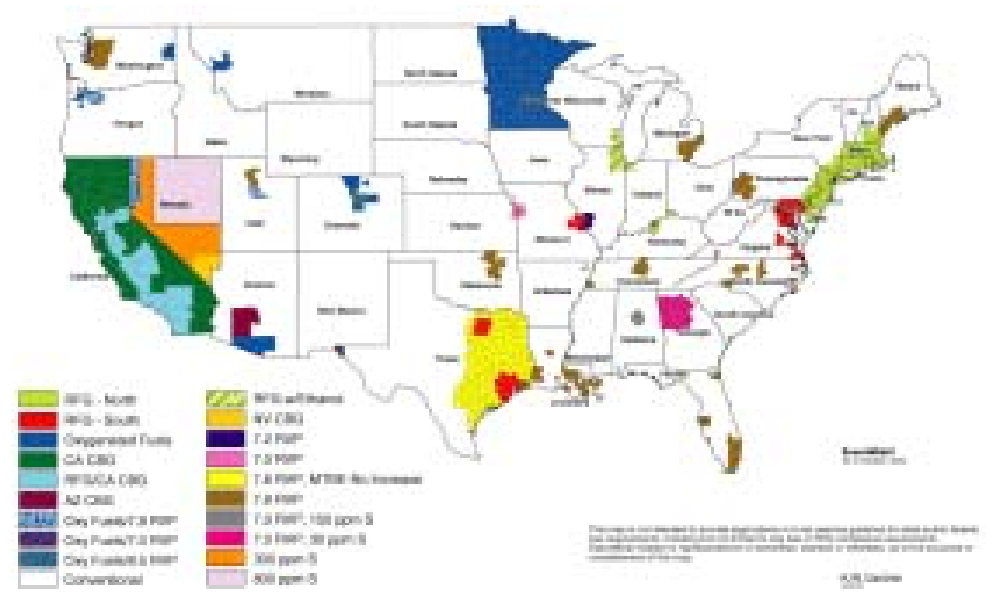




\section{REPORT DOCUMENTATION PAGE}

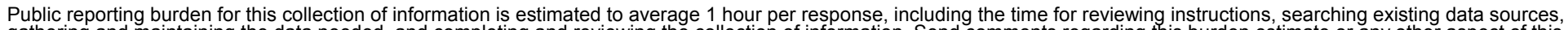

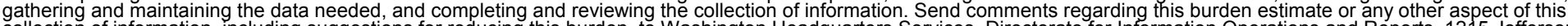

collection of information, including suggestions for reducing this burden, to Washington Headquarters Services, Directorate for Information Operations

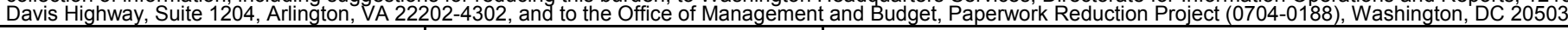

\begin{tabular}{|l|l|l}
\hline 1. AGENCY USE ONLY (Leave blank) & $\begin{array}{c}\text { 2. REPORT DATE } \\
\text { August } 2003\end{array}$ & $\begin{array}{l}\text { 3. REPORT TYPE AND DATES COVERED } \\
\text { Subcontract Report May } 2002-\text { May } 2003\end{array}$ \\
\hline
\end{tabular}

4. TITLE AND SUBTITLE

5.

Reaching the Environmental Community: Designing an Information Program for the NREL Biofuels Program

6. $\operatorname{AUTHOR}(\mathrm{S})$

Environmental and Energy Study Institute

7. PERFORMING ORGANIZATION NAME(S) AND ADDRESS(ES)

8.

Environmental and Energy Study Institute

122 C St., NW, Suite 630

Washington DC, 20001

Phone: (202) 662-1885; Fax: (202) 628-1825

9. SPONSORING/MONITORING AGENCY NAME(S) AND ADDRESS(ES)

National Renewable Energy Laboratory

1617 Cole Blvd.

Golden, CO 80401-3393
5. FUNDING NUMBERS

BFP2-SCA5

ACO-2-32004-01

11. SUPPLEMENTARY NOTES

NREL Technical Monitor: Howard Brown

12a. DISTRIBUTION/AVAILABILITY STATEMENT

National Technical Information Service

U.S. Department of Commerce

5285 Port Royal Road

Springfield, VA 22161

8. PERFORMING ORGANIZATION REPORT NUMBER

10. SPONSORING/MONITORING AGENCY REPORT NUMBER

NREL/SR-510-34272

13. ABSTRACT (Maximum 200 words) Final report on subcontract for holding two briefings for policymakers and the environmental community on environmental issues related to biofuels; one on the energy and environmental issues associated with biofuels production and use, and the other on implications of pending renewable fuels standard legislation.

14. SUBJECT TERMS biofuels; environment; energy balance; renewable fuel standard

15. NUMBER OF PAGES

16. PRICE CODE

17. SECURITY CLASSIFICATION OF REPORT Unclassified
18. SECURITY CLASSIFICATION OF THIS PAGE Unclassified
19. SECURITY CLASSIFICATION OF ABSTRACT Unclassified
20. LIMITATION OF ABSTRACT

UL 